\title{
KRÖNUNGSPORTRÄT FERDINANDS III. VON JUSTUS SUSTERMANS AUS DEM JAHRE 1626
}

\author{
DIE UNGARISCHE TRACHT ALS MITTEL DER MACHTREPRÄSENTATION \\ BEI DEN KÖNIGSKRÖNUNGEN ANFANG DES 17. JAHRHUNDERTS1
}

\begin{abstract}
Coronation portrait of Ferdinand III from 1626. The Hungarian costume as a tool of power representation in early $17^{\text {th }}$ century royal coronations. Archduke Ferdinand of Habsburg was crowned king of Hungary in Sopron, West Hungary, on 8 December 1625. His attire worn during the ceremony was identical with the apparel he is depicted in the portrait attributed to Justus Sustermans. The painting was engraved by Wolfgang Kilian in 1629. Though Ferdinand was crowned king of Bohemia in 1627, the engraving shows him in the costume worn during the Hungarian coronation. The Hungarian attire first received a symbolic role in the monarchic representation of Habsburg kings at the coronation of Matthias II as king of Bohemia: he entered the electoral diet and coronation ceremony in Prague in the Hungarian costume, and the Bohemian coronation medals also feature him in Hungarian clothes. That is how he is depicted in the portrait by Hans von Aachen, in which the Bohemian crown and the Hungarian costume jointly represented the dual (Hungarian-Bohemian) royal title.

The Hungarian costume also had a protocol role in diplomatic relation with the Ottomans: the Viennese envoys appeared in the sultan's court wearing Hungarian attire, because the monarchic power of the Habsburgs was exclusive acknowledged by the Ottoman Turks in their dignity as kings of Hungary. In West Europe, the costume of the Hungarians defending the eastern frontiers of Christendom implied the meaning of the protectors of the faith and was integrated in the representation of the Habsburgs toward Europe in this sense.

The first known owner of the portrait is Diego Mexía Felipez de Guzmán, marquis Leganés, whose inventories for 1637 , 1642 and 1655 include the painting as item 475, without the painter's name. The number is still visible on the painting. The Madrid picture collection of Leganés was the most significant collection by a Spanish aristocrat, a third comprising portraits of members of European royal families and nobility.

The historic significance of the portrait of Ferdinand III is the highly accurate, in colour true depiction of the Hungarian crown, one of the earliest authentic renderings of the insignia. The exact details suggest that it was surveyed in person, but the order of keeping the coronation insignia only made viewing possible during the coronation. Literature registers that Sustermans visited Vienna twice, for a lengthier period in 1623-1624 to depict members of the ruling family. The portrait of Ferdinand III suggests he made a third trip, at the time of the coronation in Sopron. According to the inscription on the back, the picture was made in January 1626, presumably already in Florence. It passed from a private owner abroad into the collection of the Hungarian National Gallery in 1992.

Keywords: $17^{\text {th }}$ century, portrait representation, Hungarian costume, Hungarian Royal Crown, ruler portrait, collection of paintings, Justus Sustermans, Wolfgang Kilian, Ferdinand III King of Hungary, Matthias II King of Hungary, Diego Mexía Felipez de Guzmán Marqués de Leganés
\end{abstract}

Auf dem Reichstag 1625 in Ödenburg (Sopron) haben Vertreter der ungarischen Stände auf Intervention des Erzbischofs von Gran (Esztergom), Péter Pázmány (1616-1637), und des Palatins Nikolaus Esterházy (1625-1645) den Sohn von Kaiser und König Ferdi-

\footnotetext{
* Enikô Buzási, art historian, Budapest; e-mail: buzasieniko@gmail.com
}

nand II. (1619-1637), den damals kaum 18-jährigen Erzherzog Ferdinand Ernst, zum König gewählt. Zu diesem Zeremoniell kam es am 8. Dezember in der Ödenburger Franziskanerkirche, die laut des Berichtes von Carlo Caraffa, dem anwesenden päpstlichen Nuntius (1621-1628), zu diesem Anlass mit heraldischem Schmuck verziert war: Ihr Boden war rot-weiß-grün drapiert $^{2}$ (Abb. 1). 


\section{„VESTITO ALL'UNGHERA“ - DAS BILDNIS DES UNGARISCHEN KÖNIGS FÜR EUROPA}

Die Verwendung der ungarischen heraldischen Farben als repräsentative Verzierung der Krönungszeremonie ist nicht ohne Vorgeschichte: 1608 wurde für die Krönung von Matthias II. (1608-1619) der Weg von der St. Martini-Kirche in Pressburg (Pozsony/Bratislava, SK) bis zur Franziskanerkirche, dem Schauplatz des Schlages zum Ritter vom Goldenen Sporn, mit rot-weiß-grünen Teppichen statt der bis dahin üblichen dunkelroten Draperie belegt. ${ }^{3}$ Die Farbenwahl mit heraldischem Sinn hatte ihren Platz auch beim Erscheinungsbild Ferdinands III. Ende 1625: Das unter dem Mantel bei früheren Krönungen getragene und laut der Quellen als dunkelrote Kleidung beschriebene Krönungsgewand ${ }^{4}$ war nämlich in diesem Fall silberfarbig, sodass es, mit dem dunkelroten Schalgürtel und den gleichfarbigen engen Hosen ergänzt, den heraldischen Farben des Arpadenhauses, d.h. den mittelalterlichen ungarischen Traditionen, entsprach. Die Beschreibung des päpstlichen Nuntius geht aber weiter und lässt uns wissen, dass der neue Herrscher „vestito all'Unghera" erschien, d.h. neben einem Silberbrokat-Gewand sowie einer dunkelroten
Samtmente mit Zobelpelz einen mit Reiherfedern und Diamantenfederbusch geschmückten Hut in ungarischem Stil trug. ${ }^{5}$ Ähnlich berichten über seine Krönung die in jüngster Zeit erschlossenen spanischen Quellen, die den Erzherzog - in Übereinstimmung mit dem Nuntius - als "vestido a la húngara“ erwähnen. ${ }^{6}$

Mit einer der Beschreibung des Augenzeugen in jeder Hinsicht entsprechenden Aufmachung und in seiner Würde als König wird der junge Herrscher erstmals auf dem Ganzfigurenporträt festgehalten, das 1992 als Werk eines unbekannten Malers aus ausländischem Privatbesitz in die Sammlung Alte Kunst der Ungarischen Nationalgalerie geriet. ${ }^{7}$ Noch vor dem Erwerb des Porträts gelang es mir, es als Werk von Justus Sustermans (1597-1681), dem Porträtmaler flämischer Abstammung am Florentiner Hof, zu identifizieren, der auch für Kaiser Ferdinand II. gearbeitet hatte. ${ }^{8}$ Die Bestimmung, die auch durch einen Antwerpener Forscher bestätigt wurde, ${ }^{9}$ war seither auch in die Literatur des Bildnisses integriert, ${ }^{10}$ so gehe ich im Weiteren nicht mehr auf Einzelheiten der Zuschreibung ein (Abb. 2).

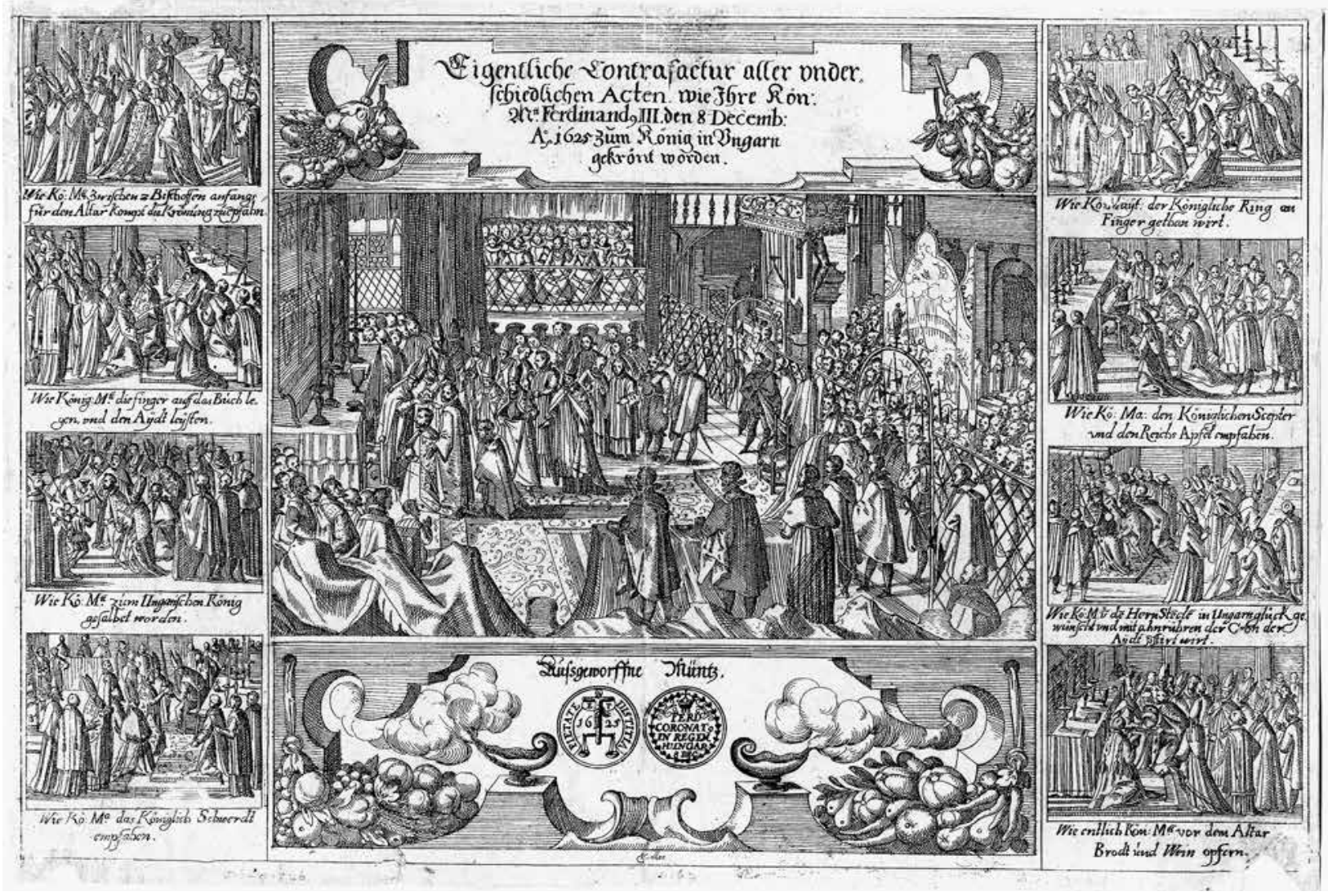

Abb. 1. Unbekannter Stecher: Ferdinands III. Krönung am 8. Dezember 1625 in der Ödenburger Franziskanerkirche, 1626; Kupferstich; Budapest, MNM TKCs (Foto des Museums) 


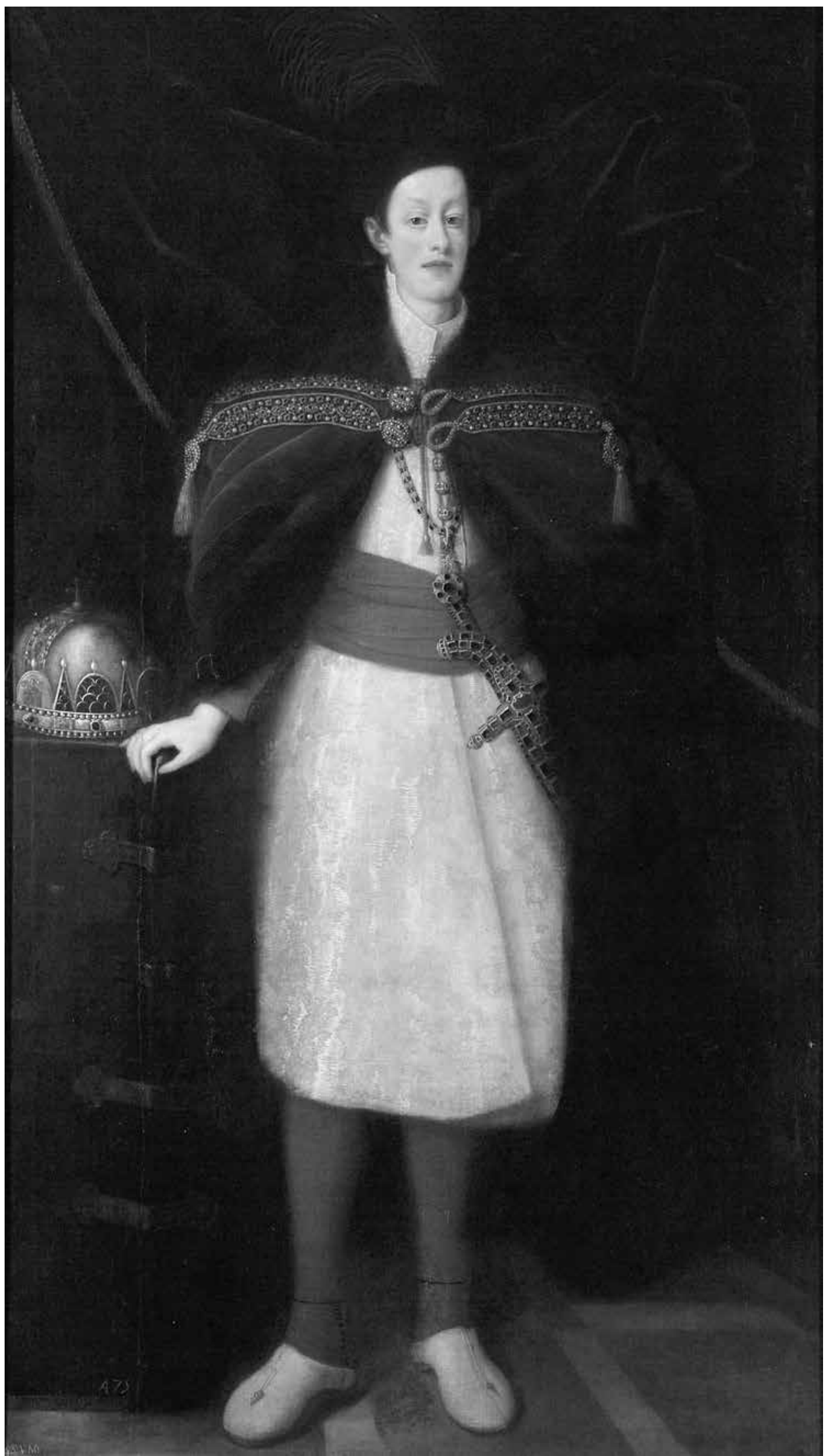

Abb. 2. Justus Sustermans (1597-1681) und seine Werkstatt: Ferdinand III. als ungarischer König, 1626; Budapest, MNG RMGy (Foto: Archiv der Verfasserin) 
Das erste offizielle Bildnis des neuen Herrschers verdient auch von dem Gesichtspunkt aus besondere Aufmerksamkeit, dass Ferdinand III. durch den nach dem Bildnis gefertigten Stich, d. h. in dem Gewand, das er im Dezember 1625 während der Krönung in Ödenburg trug, für Europa nicht nur als König Ungarns, sondern auch Böhmens bekannt wurde (Abb. 3). Das Blatt Wolfgang Kilians (1581-1662), das nach der Prager Krönung zum böhmischen König vom Jahr 1627 erschien, betont mit der Übernahme der ungarischen Adelstracht - trotz der Tatsache, dass Ferdinand in der Überschrift Herrscher Ungarns und Böhmens genannt wird - allein seine Würde als König von Ungarn. ${ }^{11}$ Der Augsburger Stecher fertigte das Bildnis im Jahr 1629 für ein Band, das die Ahnen des Hauses Habsburg von Rudolf I. an darstellte, in dem die Reihe der Porträtstiche mit dem - im Band allein von Kilian signierten Bildnis Ferdinands III. zu Ende geht. ${ }^{12}$

Stichkopien unterschiedlichen Niveaus der Darstellung in ungarischer Tracht, zumeist ohne Signatur

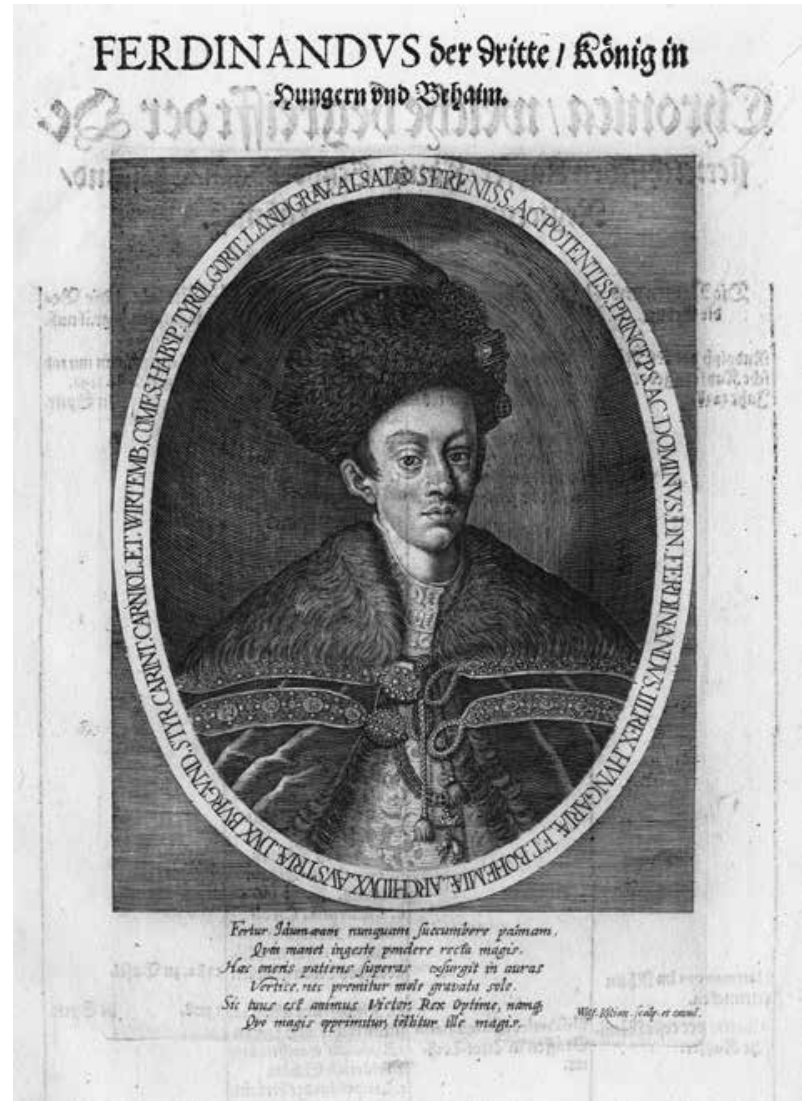

Abb. 3. Wolfgang Kilian (1581-1662): Ferdinand III. als böhmischer König in ungarischem Krönungsgewand. Erschienen in Deß aller Durchleüchtigsten Haus Oesterreichs Herzogen, Ertzhertzogen, König und Kayser... Contrafacturen, 1629; Kupferstich; Budapest, MNM TKCs

(Foto des Museums) des Meisters, erschienen in den Jahrzehnten danach in schneller Abfolge, ${ }^{13}$ wie auch Matthäus Merian diese Version benutzte, um die Ereignisse des Jahres 1631 in dem 1646 erschienenen zweiten Band des Theatrum Europaeum zu illustrieren. Die Popularität der Komposition und mit ihr der Ikonographie in ungarischer Tracht außerhalb der Habsburgermonarchie wird auch durch die Blätter namhafter, in Paris tätiger Stecher - wie des königlichen Graveurs und Herausgebers Michael van Lochom und Baltazar Moncornet belegt, die aufgrund des Vorbilds und der Titulatur in den Umschriften in den Zeitraum zwischen 1629 und 1636, d. h. zwischen die Krönungen zum böhmischen bzw. deutschen König, gelegt werden können. ${ }^{14}$ Im ungarischen Krönungsgewand ist Ferdinand jedoch auf dem Stich zu sehen, der von der Rückeroberung Regensburgs, d. h. vom ersten militärischen Erfolg des jungen Herrschers, kündet, der die kaiserliche Armee vom Frühjahr 1634 an als Oberbefehlshaber führte. Die Erstellung des Blattes, das mit der Signatur G.S.R.B. versehen ist und im Hintergrund die Belagerung der Stadt darstellt, kann genau eingegrenzt werden auf die wenigen Wochen zwischen der Einnahme Regensburgs (Juli 1634) und dem habsburgischen

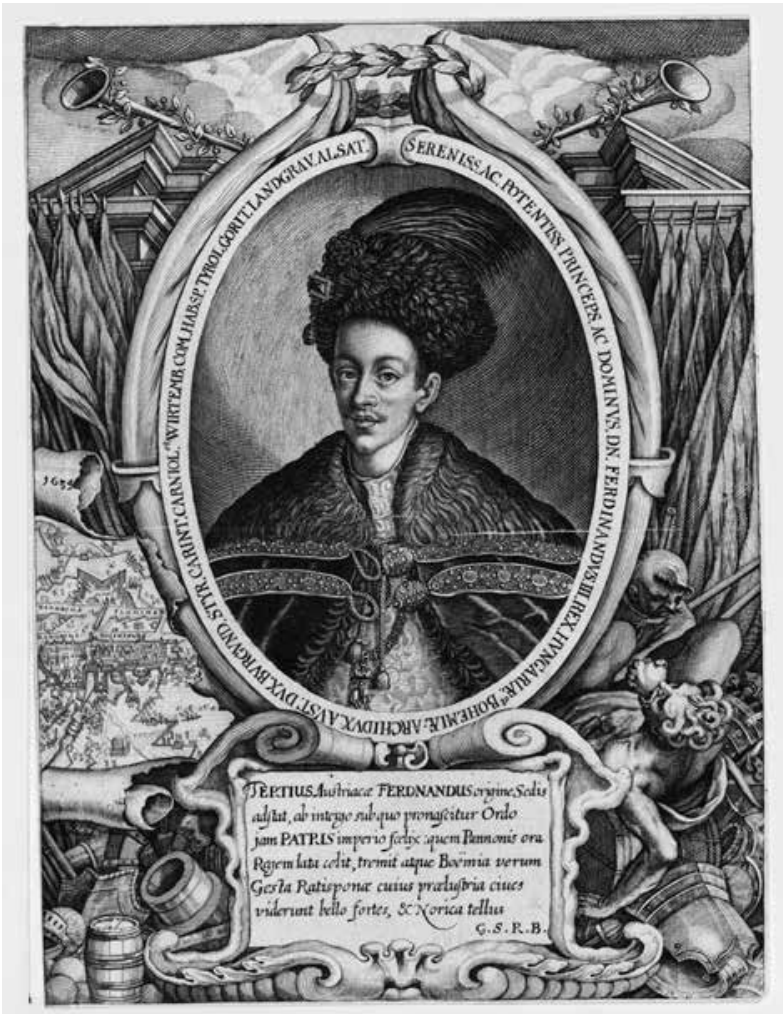

Abb. 4. Mit der Signatur G.S.R.B.: Ferdinand III., Sieger der Schlacht bei Regensburg, 1634; Kupferstich; Wien, ÖNB Bildarchiv (Foto der Bibliothek) 
Sieg über die mit den Schweden verbündeten Protestanten, der Schlacht bei Nördlingen (6. September 1634) $)^{15}$ (Abb. 4).

Insgesamt weisen also die Kilian-Komposition und deren zahlreiche Versionen und Nachstiche darauf hin, dass die bei der ungarischen Krönung getragene Tracht im Protokoll des als König Ungarns und
Böhmens aufgetretenen Herrschers bis zur Wahl bzw. Krönung Ferdinands III. zum deutsch-römischen Kaiser (22. bzw. 30. Dezember 1636, Regensburg) besondere Bedeutung erhielt. Da die Würde König von Ungarn in seiner Titulatur bis Ende 1636 den höchsten Rang genoss, repräsentierte er dadurch und mit diesem Auftreten unter den Herrschern Europas. ${ }^{16}$

\section{MATTHIAS II. - DIE UNGARISCHE TRACHT IM BÖHMISCHEN KRÖNUNGSPROTOKOLL}

Aus der Zeit vor der Krönung 1625 in Ödenburg wissen wir lediglich über einen einzigen aus dem Haus Habsburg stammenden ungarischen König, der auf seinen Porträts in der Tracht seines Landes vor Europas Öffentlichkeit getreten war. Das war Matthias II., dessen vornehmster Titel bis zu seiner Krönung zum Kaiser im Jahre 1612 - ähnlich wie bei Ferdinand III. ebenfalls König von Ungarn war. Der mit seiner Krönung beginnende und nach dem Bildnismaterial zu urteilen als konsequent geltende ikonographische Wechsel ist genügend augenfällig, um behaupten zu können: Die habsburgische Repräsentation, die in den offiziellen Auftritten des Herrschers den bildlichen und inhaltlichen Elementen der Antiquität den Vorrang gegeben hatte ${ }^{17}$ und sich bis Anfang des 17. Jahrhunderts von jeder möglichen Form der nationalen Äußerlichkeit zurückhielt, bot vom Thronantritt Matthias II. im Herbst 1608 an - parallel zum Ausgleich mit der ungarischen politischen Elite ${ }^{18}$ - der Herausbildung des Bildes des "nationalen Königs"19 im Landesprotokoll immer mehr Raum. Hierbei können wir an den nationalen Pomp der in der Einleitung erwähnten beiden ungarischen Königskrönungen genauso denken, wie an die Herrscherdarstellungen in ungarischer Tracht, deren Reihe mit dem Porträt von Matthias II. beginnt.

Der Stich des Augsburgers Lucas Kilian (15791637), eines der am häufigsten reproduzierten Porträts von Matthias II., zeigt den neuen ungarischen Herrscher in einem sorgfältig festgehaltenen Krönungsornat: mit der getreu dargestellten Heiligen Krone auf dem Haupt, mit einem ungewöhnlich präzise abgebildeten ungarischen Krönungsmantel auf den Schultern sowie mit Zepter und Reichsapfel in den Händen. Abgesehen von den Gold- und Silbermünzen und Jetons, die zur Krönung geprägt wurden und auf denen der Herrscher in Brustharnisch und - gemessen an den Möglichkeiten der Kunstgattung mit der detailgetreuen Heiligen Krone zu sehen ist, ${ }^{20}$ ist das die erste Darstellung, die wir von einem Habs- burgherrscher in seiner ungarischen staatsrechtlichen Würde kennen. Eine weitere Besonderheit besteht darin, dass der Kupferstich, der den König in seinem ganzen Ornat darstellt, zwei Jahre nach der Zeremonie vom 19. November 1608 in Pressburg, im Jahr 1610 gefertigt wurde. Die Aufschrift des datierten Porträts bezeichnet Matthias neben dem tatsächlich getragenen Titel des Königs von Ungarn nur als künftigen (Designatus) Herrscher Böhmens. ${ }^{21}$ Die zweite Version aus dem Jahr 1611 benennt ihn aber schon mit modifiziertem Text als gekrönten König Böhmens, allerdings weiterhin in der Kleidung der ungarischen Krönungszeremonie. ${ }^{22}$ Der Unterschied besteht lediglich darin, dass auf dem Wappenschild in der Kartusche des 1610 angefertigten Porträtstiches das ungarische Wappen, auf dem Exemplar aus dem Jahr 1611 hingegen bereits das vereinigte ungarisch-böhmische Wappen zu sehen ist (Abb. 5-6).

Gewiss erklärt nicht nur die unveränderte Übernahme der Porträtdarstellung, dass Matthias II. auf der zweiten Ausgabe des Stiches, die bereits nach seiner Krönung zum böhmischen König 1611 entstand, in ungarischer Krönungsgala erschien. Die Repräsentation des Herrschers war nämlich auch schon als Anwärter auf die böhmische Krone mit dem ungarischen Königstitel verbunden: So stellt ihn auch der Stich des Nürnberger Heinrich Ulrich dar, der zwar nicht genau datiert werden kann, ihn aber in der Umschrift als gekrönten ungarischen und designierten böhmischen König beschreibt. Das Blatt wurde also vor der Krönung am 23. Mai 1611 in Prag gefertigt ${ }^{23}$ (Abb. 7). Dieses Erscheinungsbild wird auch durch jenen zeitgenössischen Bericht dokumentiert, nach dem der werdende böhmische Herrscher nach seiner Ankunft zum Krönungsreichstag am 24. März 1611 in einem ungarischen Scharlachkleid und einem mit Reiherfedern geschmückten Hut in Prag einzog. ${ }^{24}$ Seiner ungarischen Tracht kam auch später im Krönungsprotokoll eine Rolle zu - so wurde die Verkörperung der ungarischen Königswürde in seiner Person betont. 


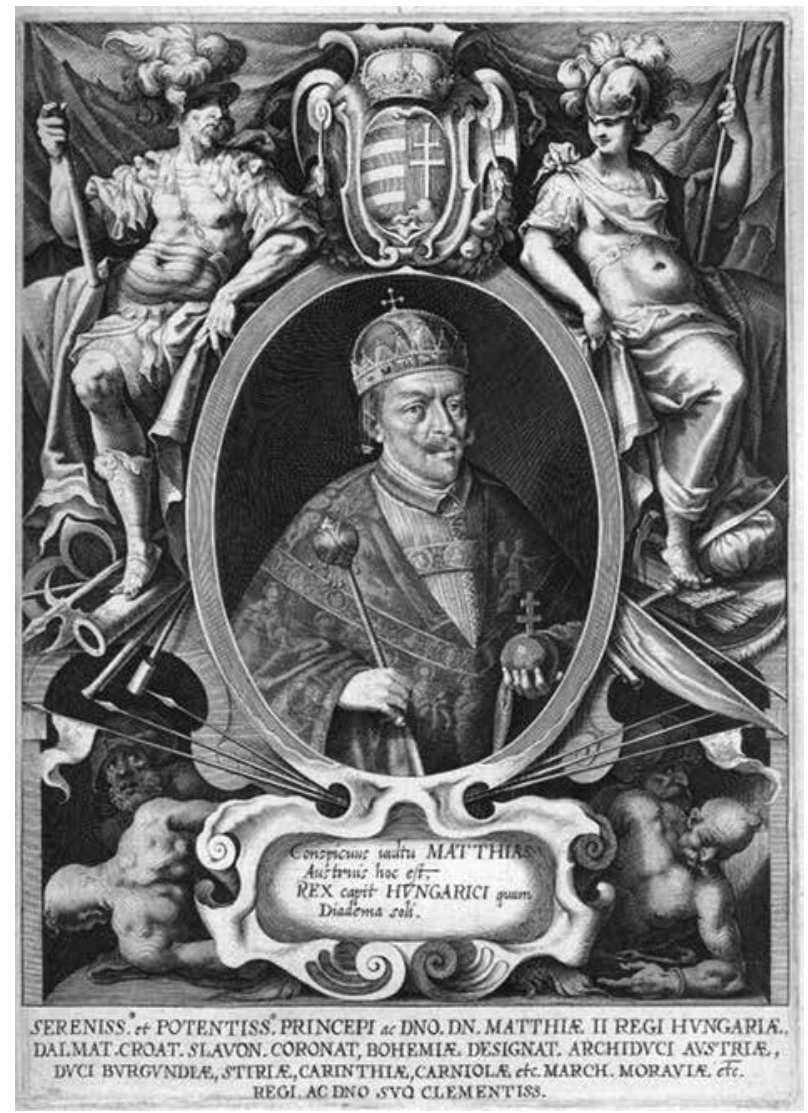

Abb. 5. Lucas Kilian (1579-1637): Matthias II. in ungarischem Krönungsornat nach seiner Krönung zum ungarischen König, 1610; Kupferstich;

Budapest, OSZK RMNy (Foto der Bibliothek)

Diese Bedeutung der ungarischen Tracht galt auch, nachdem Matthias II. zum böhmischen König gekrönt wurde. In ungarischer Tracht ist er auch auf einem in Rom herausgegebenen Blatt in Zusammenhang mit der böhmischen Königskrönung abgebildet, versehen mit dem Monogramm MG. Darauf steht unter seinem Profilbildnis das Datum der Prager Zeremonie, ferner die Angabe, dass der Stich die Vorderseite der unter das Volk gestreuten Krönungsjetons darstellt. Auf der Balustrade unter dem Bildnis sieht man einen Storch mit einer Schlange im Schnabel - jenes Emblem, das die Rückseite mancher seiner Krönungsmedaillen schmückte, mit einem evangelischen Zitat in der Umschrift ${ }^{25}$ (Abb. 8). Weitere Exemplare der Medaille zeigen das Datum der Krönung, das Profilbild des Herrschers in ungarischer Kleidung befindet sich jedoch auf jeder. ${ }^{26}$

Die ungarische Tracht von Matthias II. während der Königswahl in Prag und der Krönungsereignisse als Mittel der Machtrepräsentation wird durch das Detail der Krönungszeremonie (die sog. acclamatio) am ehesten interpretiert, da - übereinstimmend mit

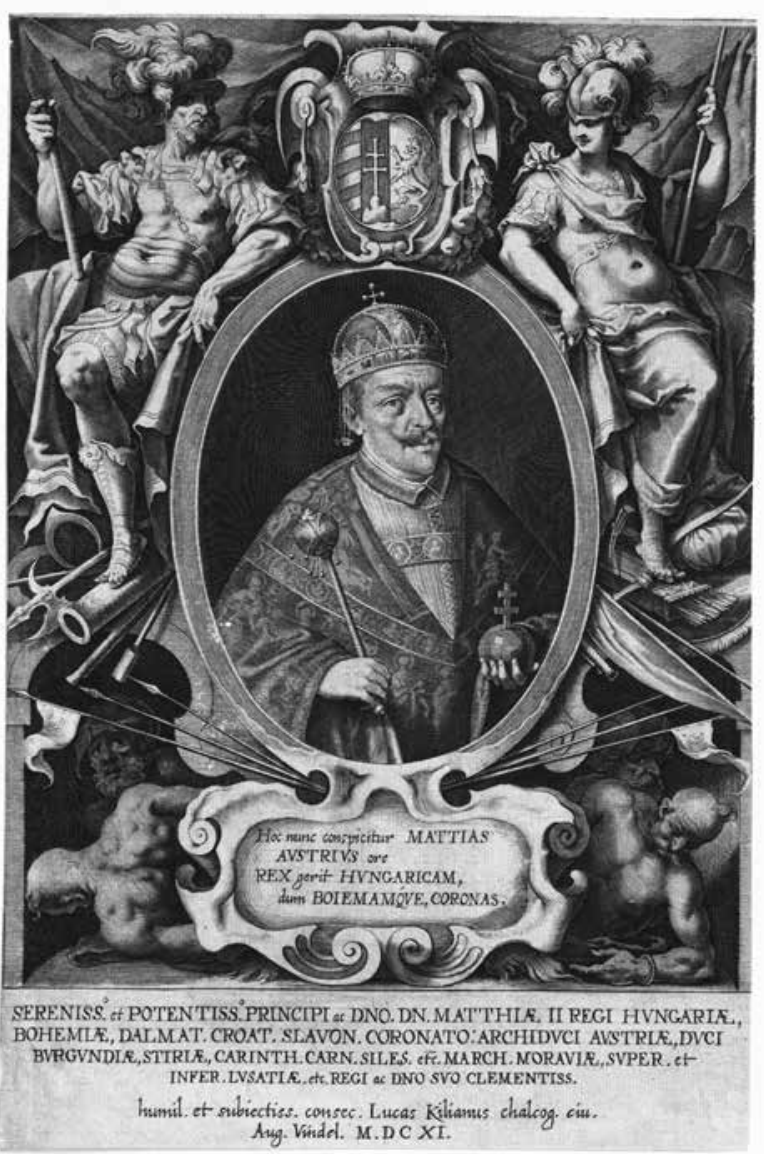

Abb. 6. Lucas Kilian (1579-1637): Matthias II. in ungarischem Krönungsornat nach seiner Krönung zum böhmischen König, 1611; Kupferstich;

Wien, ÖNB Bildarchiv (Foto der Bibliothek)

dem entsprechenden Moment der ungarischen Krönung - den Vertretern der böhmischen Stände die Frage gestellt wurde, ob sie Matthias, Ungarns König, als ihren eigenen König akzeptieren. Die Antwort darauf war ein dreifaches „Ja“. ${ }^{27}$ Das heißt, dass die böhmischen Stände den ungarischen König Matthias II. haben wollten und ihn auf den Thron setzten, nicht aber den habsburgischen Erzherzog Matthias.

In welcher seiner Würden der jeweils gewählte Herrscher übrigens die Salbung vor der Krönungszeremonie entgegennahm und das Ornat angelegt bekam, das kam auch früher durch die Kleidung zum Ausdruck, obwohl dieses Moment der böhmischen Krönung nach unseren derzeitigen Kenntnissen im Laufe des 16. Jahrhunderts kaum erwähnt wird. Über die Krönung Ferdinands I. (damals in der Tat noch österreichischer Erzherzog) 1527 in Prag ist eine Beschreibung erhalten geblieben. Aus ihr ist ersichtlich, dass ihn der beim Einzug in die Kirche getragene Erzherzogshut sowie der weinrote Samtmantel mit Hermelin 


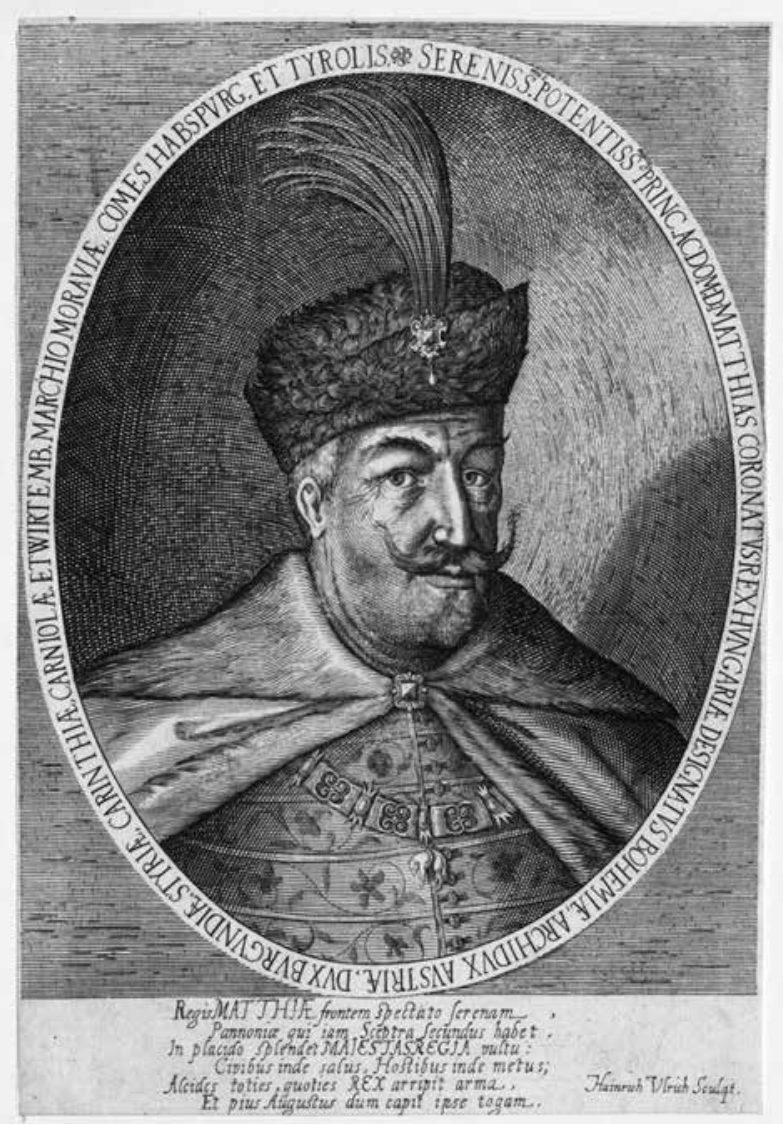

$A b b .7$. Heinrich Ulrich (nachweisbar zwischen 1572 und 1621): Matthias II. als designierter böhmischer König, vor 1611; Kupferstich; Wien, ÖNB Bildarchiv (Foto der Bibliothek)

- verständlicherweise - in seiner Würde als Erzherzog anführten. ${ }^{28}$ Die alleinige bekannte Ausnahme war die Krönung von Matthias II. im Frühjahr 1611: Bei der Zeremonie erschien er nach der Beschreibung in den Quellen des böhmischen Reichstags als Ungarns König in ungarischer Tracht, in einem langen, mit weißsilbernem Tuch gefütterten grünsamtenen Über-

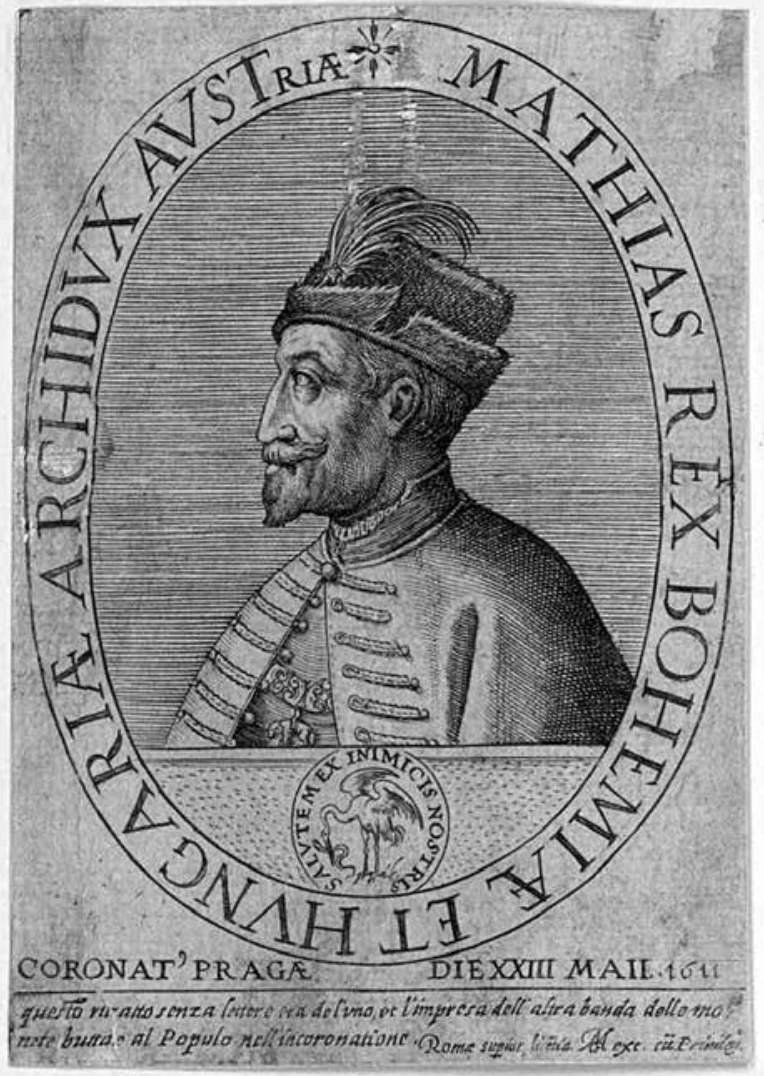

Abb. 8. Römischer Stecher mit dem Monogramm MG: Matthias II. als böhmischer König, 1611 bzw. nach 1611; Kupferstich; Wien, ONB Bildarchiv (Foto der Bibliothek)

rock (Mente) und einem schwarzen Hut mit schwarzem Federbusch. Das Ziel in diesem Fall war es, den mit der böhmischen Krönung entstandenen doppelten (ungarisch-böhmischen) Königstitel zum Ausdruck zu bringen und sichtbar zu machen, was sich am eindeutigsten durch die ungarische Kleidung des Herrschers realisieren ließ. ${ }^{29}$

\section{DIE UNGARISCHE TRACHT AUF DEN HERRSCHERBILDNISSEN VON MATTHIAS II.}

Die ungarische Tracht erhielt mit ähnlicher Bedeutung ihren Platz auch auf einem der bekanntesten und repräsentativsten Stücke der Ikonographie von Matthias II., auf dem Ganzfigurenporträt von Hans von Aachen (1552-1615). Man sieht ihn auf dem Bild als böhmischen und ungarischen Herrscher, mit den böhmischen Krönungsinsignien (Krone und Zepter). Seine Bekleidung signalisierte seine Würde als ungarischer König: eine pelzgefütterte Mente mit Schnurverzierung, ein Hut sowie der lange Seidendolman in ungarischem Stil geschneidert, mit vielen Knöpfen und mit Pfaufedermotiv geschmückt ${ }^{30}$ (Abb. 9). Das Gewandmuster, das sich auf den Pfau als eines der wichtigen Elemente der habsburgischen heraldischen Repräsentation bezieht, präsentiert in diesem Porträt, das mit symbolischen Andeutungen kommuniziert, eine besondere ikonographische Wendung für die Zeitgenossen. Der Maler brachte damit, dass er der Kleidung, die den Ungarkönig symbolisierte, eine Deutung mit Bezug auf die Herrscherfamilie der Habs- 


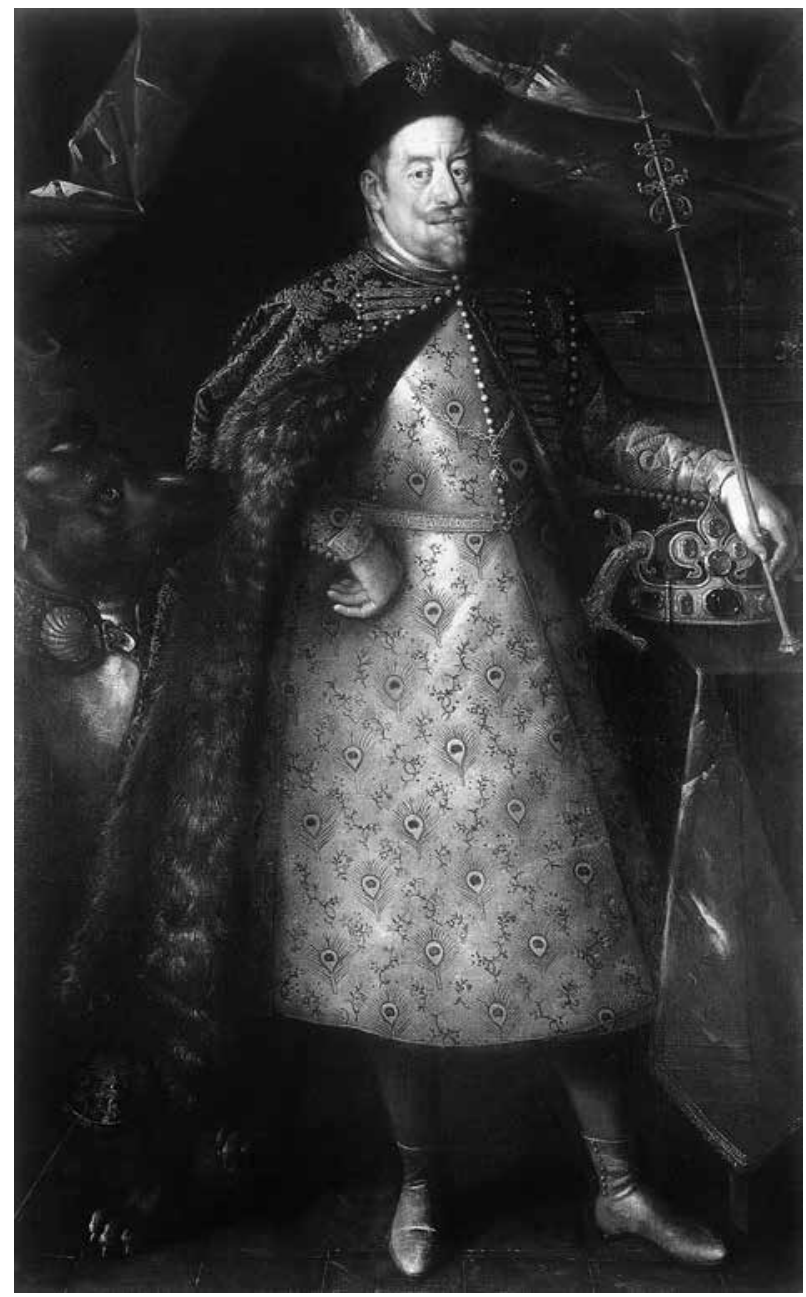

Abb. 9. Hans von Aachen (1552-1615): Matthias II. als ungarischer und böhmischer König, 1611-1612; Praha, Sbírky Pražského hradu (Reproduktion)

burger verlieh, ${ }^{31}$ die innerhalb der Habsburgermonarchie herrschenden Machtverhältnisse, $d$. h. die wahre politische Lage, zum Ausdruck.

In der Bekleidung von Matthias II. auf Hans von Aachens Porträt hat Eliška Fučíková die ungarische Tracht erkannt. Wegen des einzigen Hoheitszeichens, der böhmischen Krone, die neben dem Herrscher dargestellt ist, setzte sie das Datum vor die Erlangung der deutsch-römischen kaiserlichen Würde (13. Juni 1612). ${ }^{32}$ Mit dem Bildnis für fast gleichaltrig hielt sie die in Wien aufbewahrte, laut einzelner Forscher mit Werkstatthilfe gefertigte Version des Porträts, die Matthias als böhmischen König, in vollem Krönungsornat, mit all seinen Hoheitszeichen (Krone, Zepter und Reichsapfel) zeigt ${ }^{33}$ (Abb. 10). Rüdiger an der Heiden, der das Schaffen des Malers in einem monographischen Aufsatz bearbeitete, setzte das Prager Porträt auf die Jahre 1612-1613, während die Wiener Version - bei der er für möglich hielt, dass

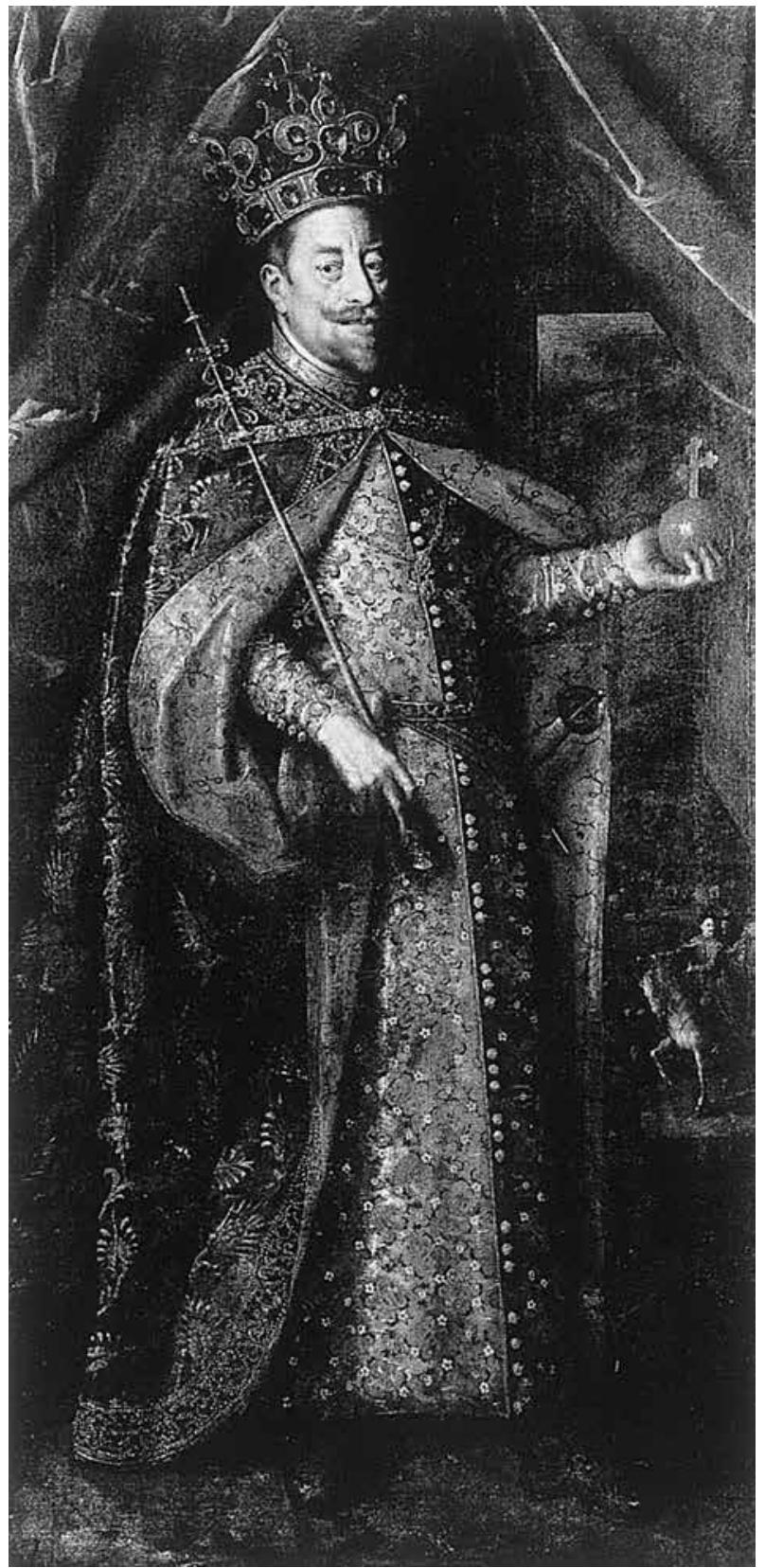

Abb. 10. Hans von Aachen (1552-1615) und seine Werkstatt: Matthias II. als böhmischer König, 1611-1612; Wien, KHM (Reproduktion)

der Kopf von eigener Hand herausgearbeitet wurde auf 1613-1614. Die Datierung ist seither in keinem dieser Fälle präziser geworden, mehr noch: Aachens Monograph, Joachim Jacoby, schlug neulich vor, deren Anfertigung zwischen die Jahre 1612 und 1615 zu datieren. Vorsichtig bezog er sich darauf, dass auf der von der Witwe des Malers 1615 eingereichten (schon bisher bekannten) undatierten Rechnung beide Werke angeführt sind. ${ }^{34}$ Das Wiener Exemplar hat aber ein von der Literatur bisher außer Acht gelassenes Moment, wodurch das Bild wohlfundiert 


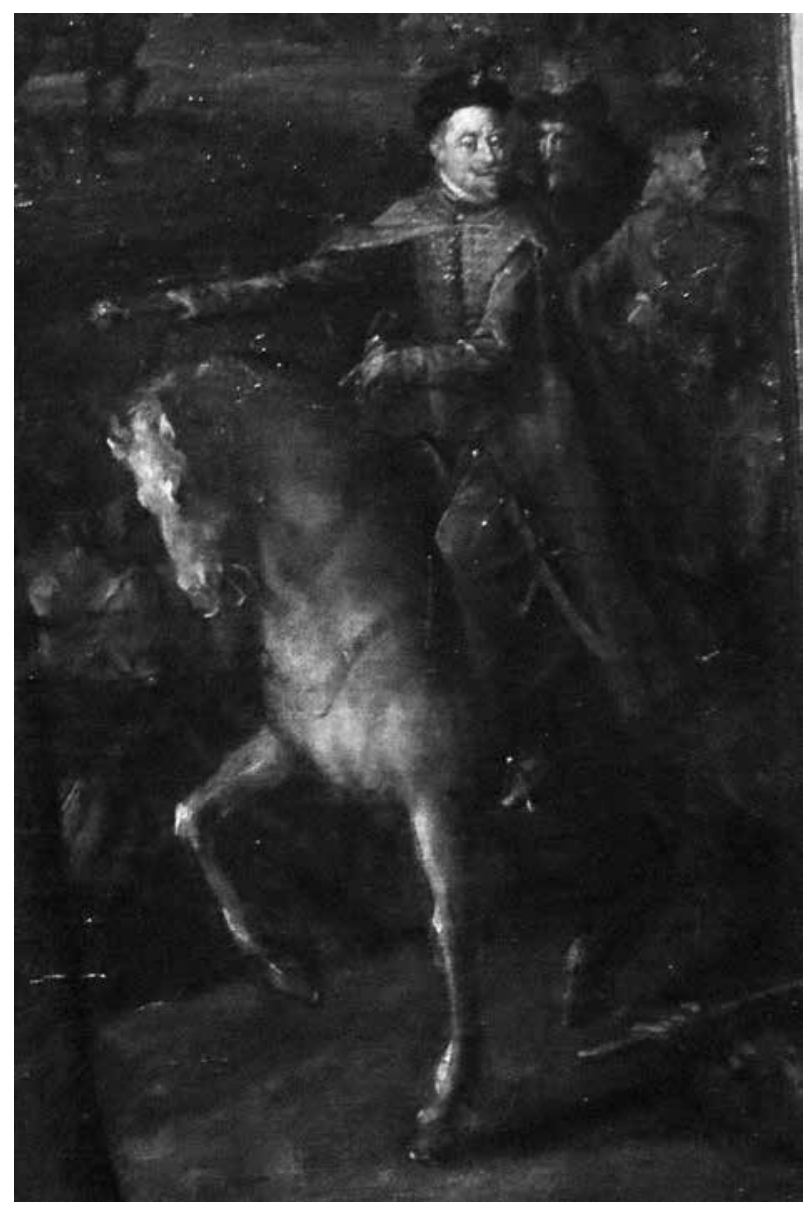

Abb. 11. Einzug von Matthias II.

am 24. März 1611 in Prag, 1611-1612; Detail von Abb. 10 (Foto: Archiv der Verfasserin)

in die Nähe der Zeit der Krönung, aber spätestens in die erste Hälfte 1612, etwa in die Zeit nahe der Version mit dem Gewand in ungarischem Stil, zu setzen ist. ${ }^{35}$ Die Darstellung rechts beinhaltet nämlich auch die Szene des Einzugs von Matthias II. in Prag (24. März 1611), auf der der Herrscher in der aus den Quellen bereits bekannten und bereits erwähnten Erscheinung zu sehen ist: in einem Scharlach-Überrock (Mente) mit einer schwarzen ungarischen Mütze und einem ungarischen Streitkolben in der rechten Hand (Abb. 11). Eine so präzise, in den Details authentische Darstellung des mit dem Akt der Krönung in Prag nicht unmittelbar verbundenen (sogar um mehrere Wochen vorangehenden) Ereignisses auf dem repräsentativen Statusporträt ist meines Erachtens einerseits ein Anhaltspunkt zum früheren Datum der Fertigstellung, andererseits dokumentiert es das protokollarische Gewicht des Auftretens als ungarischer Herrscher: die Bedeutung der ungarischen königlichen (aktuellen staatsrechtlichen) Würde des werdenden böhmischen Herrschers und dadurch die

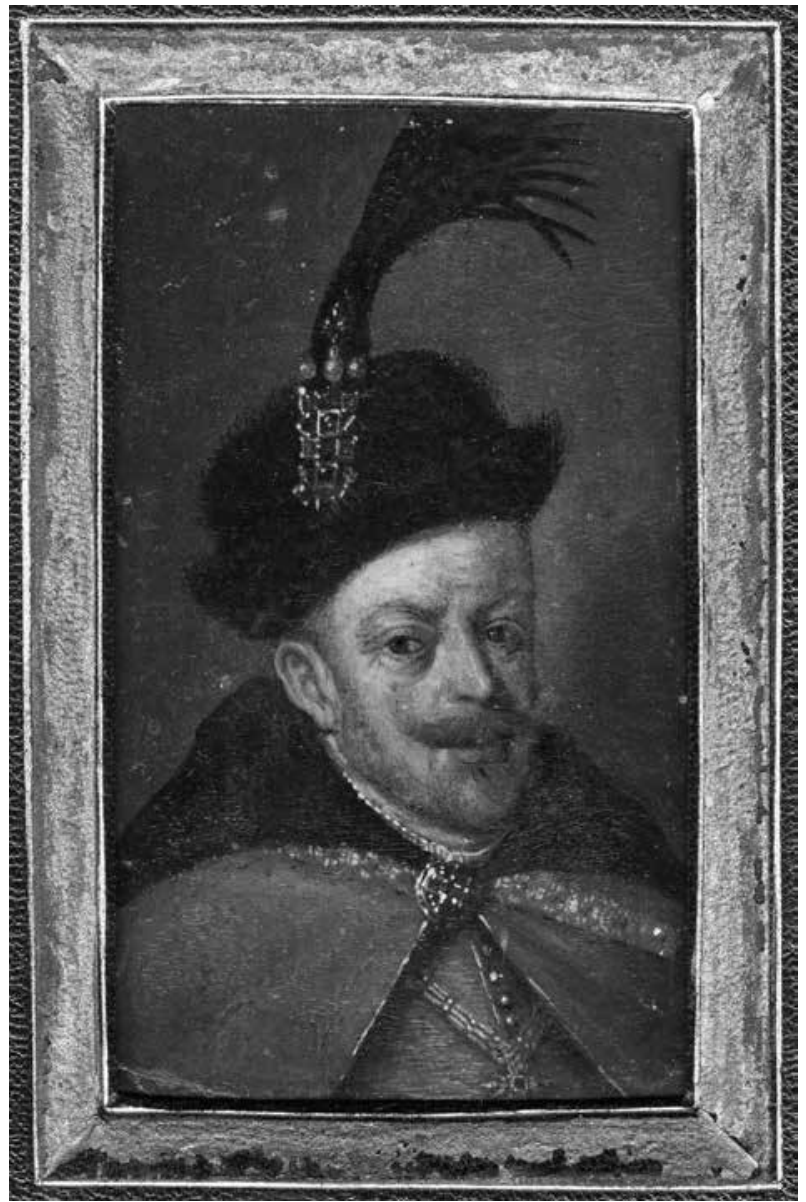

Abb. 12. Maler aus Prag oder Wien vom Beginn des 17. Jahrhunderts: Matthias II. in ungarischer Tracht, 1608-1619; Budapest, MNM TKCs (Foto des Museums)

zeitgenössische Interpretation der ungarischen Tracht außerhalb des Königreichs Ungarn.

Hans von Aachens oben angeführte Rechnung erwähnt auch weitere Porträts, die Matthias II. teilweise auf einem Brustbild, teilweise vielleicht auf einem Ganzfigurenporträt („grosse stuck“), aber in ungarischer Kleidung darstellten und die - ähnlich wie andere offizielle Werke des Malers - in den diplomatischen Kontakten eine Rolle gespielt haben könnten. ${ }^{36}$ Auf dieser Grundlage stellt sich die Frage, ob der zeitgenössische Besitzer jener zwei weiteren, in das Ungarische Nationalmuseum gelangten Miniaturporträts, die den König in einem gelben Dolman, roten Überrock mit braunem Pelzkragen und mit einem Hut - der ungarischen Mode der Epoche entsprechend mit Federbusch und schmaler Krempe zeigen, wie wir annehmen könnten, ein Ungar war. Das erste Exemplar davon, das als Vorbild diente, dürfte zwischen 1608 und dem Tod von Matthias II. 1619 entstanden sein (Abb. 12). Die qualitativ unterschiedlichen Werke mit übereinstimmender Komposition, zu denen auch 
ein mit den bisherigen annähernd gleichaltriges weiteres Brustbild (Abb. 13) gezählt werden kann, bestätigen auf jeden Fall die Verbreitung des jetzt vorgestell- ten ikonographischen Typs und die zeitgenössische Popularität der Herrscherdarstellung in ungarischem Nationalkostüm. ${ }^{37}$

\section{DIE UNGARISCHE TRACHT IM DIPLOMATISCHEN KONTAKT ZWISCHEN DEM WIENER HOF UND DER HOHEN PFORTE}

Mit dem Begriff „Bild des ungarischen Königs“ verband sich die ungarische Tracht im Laufe des 16. und 17. Jahrhunderts außerhalb der Gattung des Porträts vor allem im diplomatischen Protokoll, und zwar im Kontakt der Gesandten mit den Türken. Die Wiener Delegierten zu den Verhandlungen in Konstantinopel hatten den Vorschriften der Hohen Pforte entsprechend in ungarischer Kleidung zu erscheinen, weil die Osmanen die Herrschermacht der Habsburger lange Zeit allein in ihrer ungarischen Königswürde anerkannten. ${ }^{38}$ Bei den kaiserlichen Gesandten - unter denen es in den 150 Jahren osmanischer Herrschaft kaum einen Ungarn gab - signalisierte auf diese Weise ihr Äußeres, dass sie in Vertretung des ungarischen Herrschers handelten. ${ }^{39}$

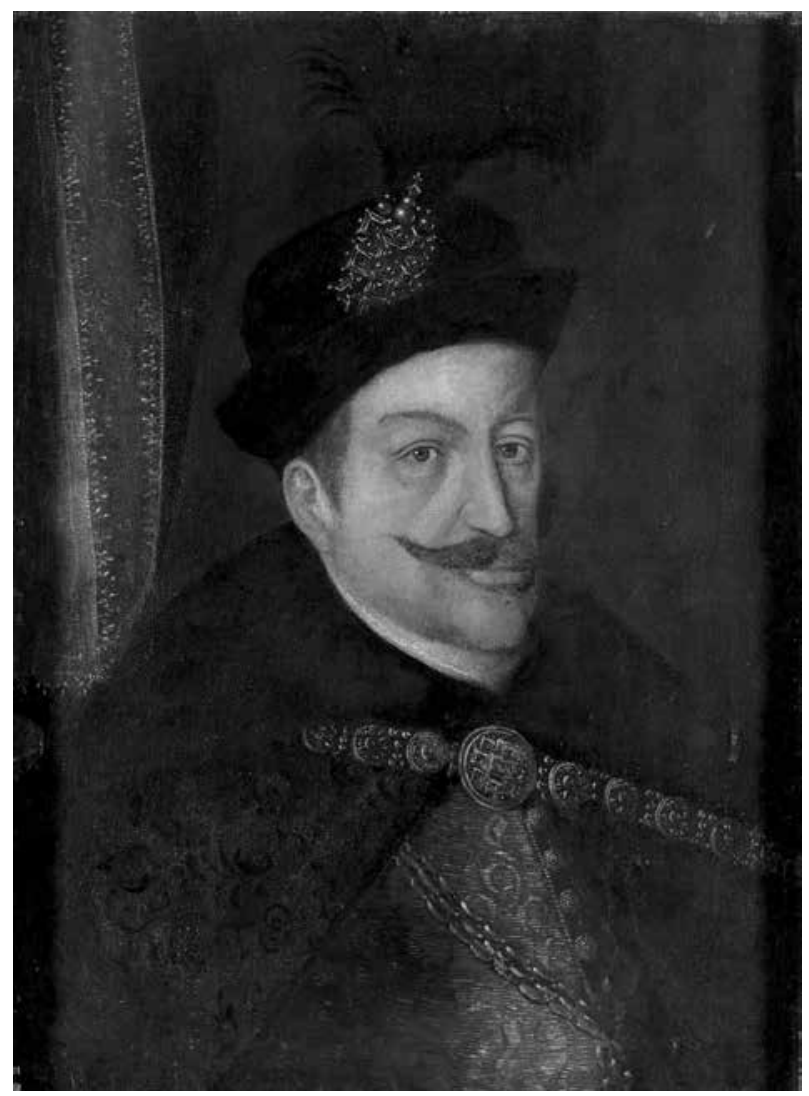

Abb. 13. Maler aus Wien (?) vom Beginn

des 17. Jahrhunderts: Matthias II. in ungarischer Tracht; Budapest, MNM TKCs (Foto des Museums)
Diese protokollarische Kleidungsvorschrift, in deren Zusammenhang Friedrich Polleroß in seiner vor Kurzem erschienenen ikonographischen Abhandlung den Begriff „Berufskleidung" gebrauchte, wird durch mehrere Kunstwerke dokumentiert. ${ }^{40}$ Eines der erstrangigen dieser Werke ist Hans von Aachens Komposition, ein Stück der Serie, die die Ereignisse des Fünfzehnjährigen Krieges (1591-1606) verewigt, das die Festnahme des in ungarischer Tracht gekleideten Gesandten in Konstantinopel, Friedrich von Kreckwitz, im Jahr 1593 in Szene setzt. ${ }^{41}$ Vermutlich können wir ebenfalls einen kaiserlichen Gesandten an der Hohen Pforte in dem bärtigen Mann identifizieren, der eine mit Hermelin gefütterte (!) ungarische Mente und einen Hut mit Federbusch trägt bzw. eine Papierrolle in der Hand hält. Sein Bildnis mit Dreiviertelansicht ist uns in Verbindung mit der Türkeireise des humanistischen Geschichtsschreibers Johannes Löwenklau 1584 in einem Kodex erhalten geblieben. Vorläufig ist es nicht gelungen, den Dargestellten selbst zu identifizieren. ${ }^{42}$ Die Person in ungarischer Tracht ist nicht identisch mit dem kaiserlichen Gesandten David von Ungnad, der sich zwischen 1573-1578 im Amt befand und dann 1585 erneut nach Konstantinopel reiste. Löwenklaus illuminierter Kodex ist nämlich teilweise als Kopie des verlorenen Türkenbuchs von Ungnad erstellt worden, das Kostüm- und Genrebilder enthielt. ${ }^{43}$

Das Bildnis des Gesandten des Wiener Hofes an der Hohen Pforte, Rudolf Schmid, ist sogar in zwei Versionen erhalten geblieben. Er bekleidete dieses Amt in den Jahren 1650 und 1651. Als er von seiner Gesandtenreise zurückgekehrt war, wurde er vom niederländischen Jeronimus Joachims in Wien porträtiert. Der von Ferdinand III. mit einem Friedensangebot nach Konstantinopel delegierte österreichische Aristokrat ist in einem nach orientalischem Geschmack eingerichteten Interieur, von Kopf bis Fuß in ungarischem Nationalkostüm auf dem Bild zu sehen, das Elias Widemann (1619-1652) kurz nach Fertigstellung wegen des damaligen Interesses auch in Kupfer stach (Abb. 14). Die Hintergrundszene, die Übergabe der Geschenke an den Sultan, zeigt ihn bei der Erfüllung seiner Mission. ${ }^{44}$ 


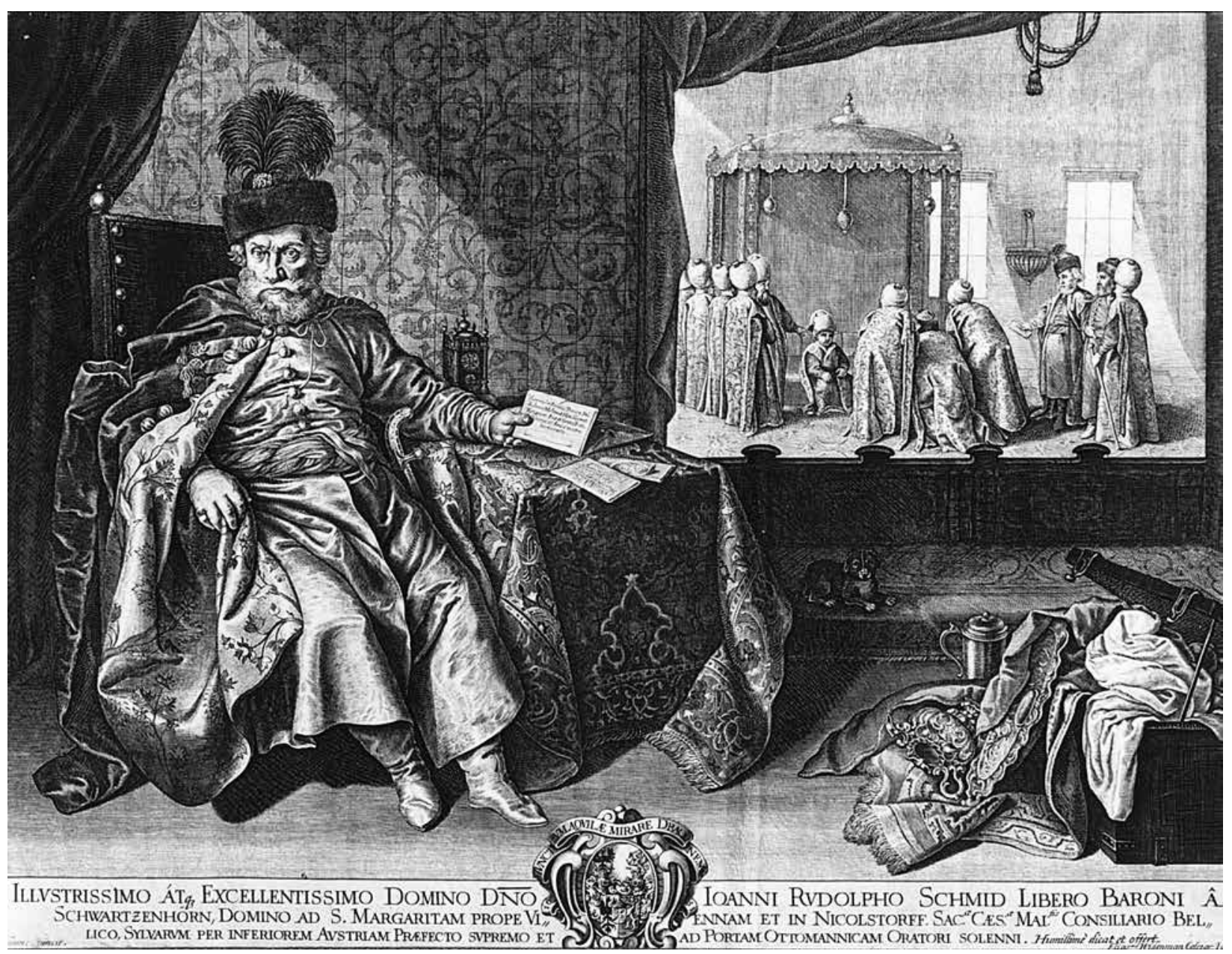

Abb. 14. Elias Widemann (1619-1652) nach Jeronimus Joachims (1629-1660): Baron Johann Rudolf Schmid, Gesandter des Wiener Hofes an der Hohen Pforte, 1651; Kupferstich; Budapest, MNM TKCs (Foto des Museums)

\section{DIE IN DER SIEGESREPRÄSENTATION INTERPRETIERTE UNGARISCHE TRACHT}

Über all das hinaus gab es auch eine andere Bedeutungsversion der ungarischen Tracht, die der Habsburg-Repräsentation als Propagandaelement eher für das westliche Publikum diente. Mit einem anderen Sinn und in einer anderen Rolle taucht nämlich die ungarische Tracht auf jenem für den Ruhm des Hauses Habsburg errichteten Triumphbogen auf, mit dem die Stadt Antwerpen im April 1635 die siegreichen Heerführer der Schlacht bei Nördlingen gegen die Schweden empfing. Die Gänze des von Peter Paul Rubens entworfenen temporären Bauwerks kennen wir von Theodor van Thuldens Stich. Auf seltene Weise blieben allerdings auch zwei Porträts erhalten, die den Triumphbogen schmückten: Das sind Werke von Jan van den Hoecke (1611-1651) über die einmarschierenden Heerführer, Ferdinand III. (der damals nur noch Ungarns König war) und Kardinal Ferdinand aus der spanischen Linie der Habsburger, Statthalter der Niederlande. ${ }^{45}$

Der Kardinal-Statthalter im Bild ist in vollem Harnisch zu sehen, wie es sich zur Militärparade gebührte, während Ferdinand III. unter seiner Pelzmente den typisch kurzen Kampfdolman der ersten Hälfte des 17. Jahrhunderts trägt, den lediglich ein leichter Brustharnisch ergänzt ${ }^{46}$ (Abb. 15). Seine ungarische Kleidung - die eindeutig militärisch und nicht adelig ist - wird bei dieser Gelegenheit nicht vom Hoheitszeichen des Herrschers begleitet, sondern vom Streitkolben, der zur Heerführer-Ikonographie gehörte. Sein Äußeres in ungarischem Stil erinnert in diesem Zusammenhang nicht an Ungarns König. Seine Tracht ist hier eine Art Heldenkostüm, dessen allgemeine Verständlichkeit - und zugleich seine Rolle für die Zeitgenossen - dem jahrhundertealten 
Beispiel der Ungarn entstammte, die die Ostgrenzen des Christentums verteidigten. Wenn wir in Betracht ziehen, dass die Habsburger als Ungarns Könige auch die Rolle der Verteidiger des Christentums vor Europa für sich beanspruchten, ${ }^{47}$ dann verband sich diese Erscheinungsweise hier mit dem anderen zentralen Programm ihrer Herrscherrepräsentation, dem
Ideal des christlichen Ritters und Helden, und zwar auch noch in dem Fall, wenn diese entscheidende Schlacht des Dreißigjährigen Krieges (1618-1648) nicht gegen die Türken, sondern gegen die protestantischen Schweden geführt wurde - laut zeitgenössischer Deutung (oder eher Erläuterung) aber dennoch „zum Schutze des Glaubens“.

\section{VORGESCHICHTE DER KRÖNUNG 1625 IN ÖDENBURG UND DER NATIONALE CHARAKTER DER REPRÄSENTATION}

Es ist eine Pikanterie der Geschichte, dass gerade die mit den verschiedenen Anlässen verbundene Repräsentation der Habsburgherrscher der Indikator war, der in den ersten Jahrzehnten des 17. Jahrhunderts die Tracht des ungarischen Adels - weil daran das eindeutig Trennende und Unterscheidende zu erkennen war - mit einer selbstständigen Bedeutung verband. Pikanterie insofern, dass die ungarische Nationaltracht, die im Laufe des Jahrhunderts zu einer entscheidenden Rolle bei der Entstehung des Identitätsbildes des Adels gelangte und dadurch auch zu einem entscheidenden ikonographischen Faktor der Galerien von Familienbildnissen wurde, durch den protokollarischen Gebrauch der Kleidung zu Beginn des 17. Jahrhunderts ihre allgemein verständliche Bedeutung im Auftreten der Habsburgherrscher als Ungarns Könige erlangte. Das kann man unter Beachtung der Tatsache sagen, dass das gelegentlich getragene ungarische Nationalkostüm seitens des Herrschers eher ein Zugeständnis war. In seiner offiziellen Eigenschaft war das nichts anderes als Illusion und Geste, die gerade deswegen innerhalb der Bedeutung des Anblicks und des Äußeren blieb. Das kann nicht anders gewertet werden, als spektakuläres Aufzeigen des momentanen und seltenen Kompromisses zwischen den zweierlei Mächten - dem Herrscher und den Ständen -, zugleich als entscheidender Teil der Symbolpolitik.

Ein König in ungarischer Nationaltracht war auch dann eine Illusion, wenn zufälligerweise Matthias II. (der sowohl die ungarische als später auch die böhmische Krone der Unterstützung durch die gegen den Kaiser Rudolf verbündeten Stände verdanken konnte) während seiner Herrschaft seine für die Erlangung der Macht den Ständen zugesagten Versprechungen und Pflichten in der Tat gebunden hatten. Die Versammelten - genauer gesagt ein bedeutender Teil von ihnen - betrachteten auch Ferdinand III., der zur Krönung 1625 in Ödenburg im ungarischen Zeremonialgewand erschien, nicht anders, denn sein Vater hatte einige Jahre zuvor am Weißen Berg und auch später für die (vor allem protestantischen) Adeligen der Monarchie keinen Zweifel daran gelassen, wie weit die Möglichkeiten des Politisierens auf ständischer Basis reichten. Der Kaiser hatte jedoch im November 1625 erhebliches politisches und dynastisches Interesse daran, die Vertreter der Stände auf dem Ödenburger Reichstag dazu zu bewegen, die Wahl seines Sohnes zum König zu akzeptieren. Die zwingende Entscheidung war - bei Bethlens teilweise immer noch vorhandene Unterstützung in Ungarn (es genügt hier, an seinen Besitz der sieben oberungarischen Komitate zu denken) - vor allem durch die geplante Ehe des Erzherzogs mit der Tochter des spanischen Königs Philipp III. (1598-1621), Infantin Maria Anna, begründet, wobei man die gegenseitig vorteilhafte Festigung des habsburgischen Bündnisses von diesem Ehebund erhoffte. ${ }^{48}$ Der spanische Hof machte nämlich den Abschluss des Ehevertrages von der Krönung Ferdinands zum König Ungarns abhängig. ${ }^{49}$ Die Erfüllung dieses Vorhabens wurde dadurch erschwert, dass die Königswahl aus Vorsicht und taktischer Überlegung heraus in dem am 10. Juli herausgegebenen Einladungsbrief des Herrschers zum Reichstag sowie in den königlichen Vorlagen vom 14. Oktober nicht enthalten war. ${ }^{50}$

Ähnlich stand auch die Palatinwahl nicht vorher auf der Tagesordnung, worauf die Stände, die von ihrem legitimen Recht Gebrauch machten, wegen des Todes des evangelischen Palatins Stanislaus Thurzó (1622-1625) am 1. Mai von Anfang an entschieden gedrängt hatten. Ein für die kaiserliche Familie günstiges Ergebnis der Palatinwahl konnte auch die Königswahl positiv beeinflussen. Die Wahl des dem Hof ergebenen katholischen Nikolaus Esterházy zum Palatin (25. Oktober) brachte auf jeden Fall die Sache der aus der Sicht Wiens nicht weiter aufschiebbaren Krönung wirklich voran. Es bestand nämlich die Möglichkeit, dass die Stände Ferdinand zur Herausgabe 


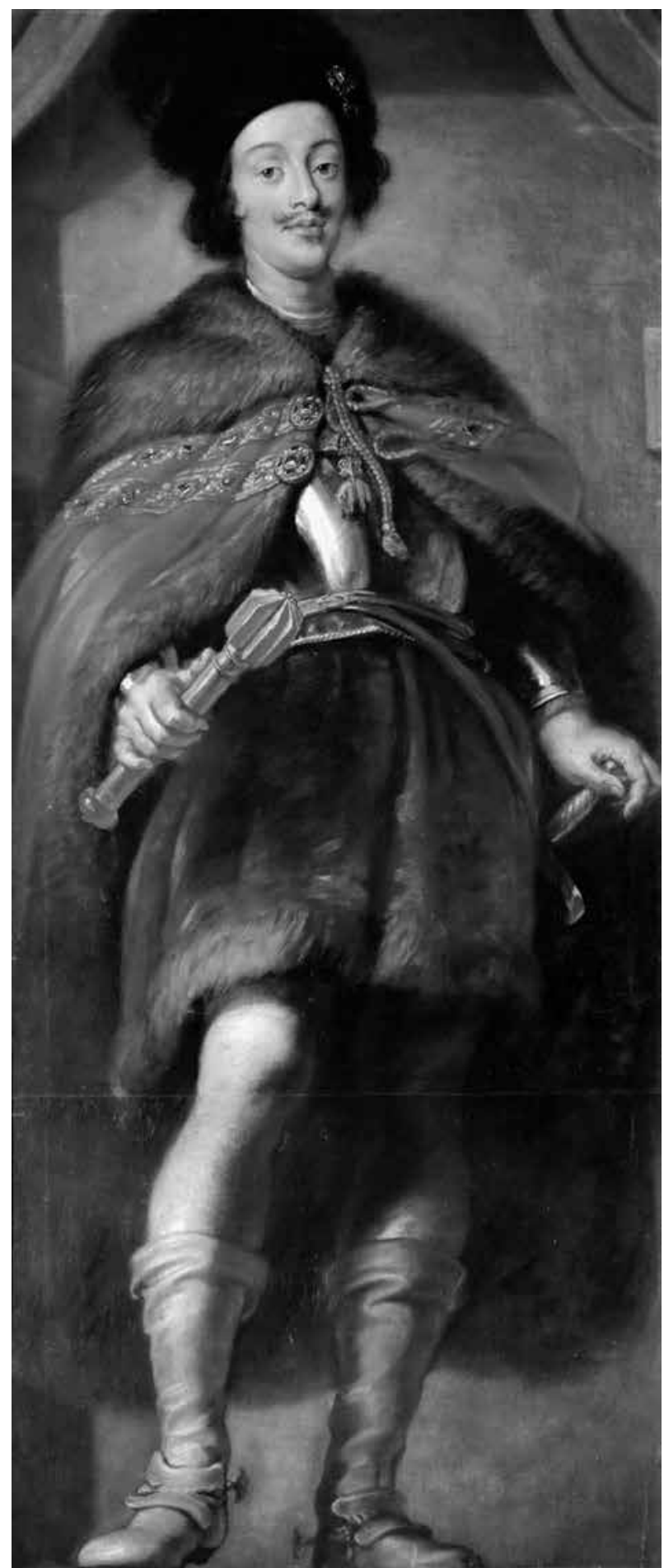

Abb. 15. Jan van den Hoecke (1611-1651):

Porträt Ferdinands III. vom Antwerpener Triumphbogen für die Sieger der Schlacht bei Nördlingen, 1635; Wien, KHM (Reproduktion)

eines Krönungsbriefs veranlasst hätten, der für die Wiener Regierung und die catholica religio ungünstige Bedingungen beinhaltet hätte, weswegen der Herrscher bei Respektierung der Ständeprivilegien, vor

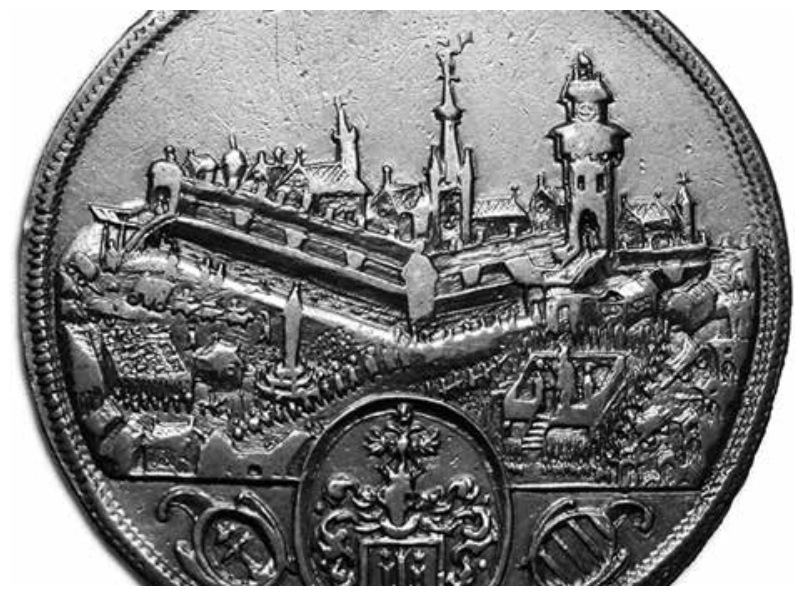

Abb. 16. Unbekannter Medailleur: Szene der Eidesleistung Ferdinands III. auf der Gedenkmedaille der Ödenburger Krönung, 1625; Sopron, Soproni Múzeum, Éremtár (Foto des Museums)

allem der protestantischen Religionsausübung, später zu Zugeständnissen gezwungen worden wäre. ${ }^{51}$ Dass der Text des Krönungsbriefs für den Hof akzeptabel wurde, war der diplomatischen Vermittlung durch den neu gewählten Palatin beziehungsweise den Graner Erzbischof Péter Pázmány in Richtung der Stände $z u$ verdanken. ${ }^{52}$ Vermutlich ist mit dieser Vorgeschichte zu erklären, dass die am Ende des Reichstags abgehaltene Königswahl (27. November) und die Krönung (8. Dezember) unter höchstem Respekt für die Empfindsamkeit und Eitelkeit des ungarischen Adels verliefen. Die „Loyalität“ der zur unerwarteten Königswahl gezwungenen Stände und die vom Palatin erwirkte Zusammenarbeit des Reichstags ${ }^{53}$ honorierte die Herrscherfamilie - von der Zustimmung der dem Hof getreuen ungarischen politischen Elite begleitet - mit spektakulären nationalen Formalitäten der Krönungszeremonie, der Illusion des „vom Willen der ständischen Nation" gewählten ungarischen Königs.

Nach all dem können wir auch die Szenenwahl der zu diesem Anlass in Wien herausgegebenen Krönungs-Gedenkmedaille, die Verewigung der weltlichen Eidesleistung auf der Rückseite der Medaille, zu Recht für eine besondere Repräsentationsgeste halten (Abb. 16). Sie hob nämlich mit einer eindeutigen Botschaft jenen Moment des Zeremoniells hervor - laut unserer Kenntnisse erstmalig auf einer Medaille abgebildet und als solche als alleinige Darstellung -, als der neue König den Eid ablegte, die in der Goldenen Bulle und in den Reichstagsbeschlüssen festgehaltenen ständischen Grundgesetze einzuhalten und die traditionellen Privilegien der Stände zu respektieren. ${ }^{54}$ 
Unter den Krönungsmedaillen Ferdinands III. war sie allerdings nicht die einzige, die sich auch in ihrer Ikonographie an den „nationalen“ Charakter des wichtigsten staatsrechtlichen Ereignisses des Königreichs Ungarn anpasste. Für die Krönung wurden auch weitere Gedenkmedaillen angefertigt, die den neuen Herrscher in ungarischem Nationalgewand und mit ungarischem Federhut darstellten - wiederum das erste $\mathrm{Mal}^{55}$ (Abb. 17). Wir haben zwar gesehen, dass die zur böhmischen Krönung geprägten Medaillen Matthias II. 1611 mit einem ungarischen Erscheinungsbild darstellten, ${ }^{56}$ auf den früher herausgegebenen Medaillen zur Krönung in Pressburg 1608 war die Ikonographie in ungarischem Stil noch nicht erschienen: Der neue König ist auf ihnen mit der Heiligen Krone, jedoch im Harnisch mit Halskrause zu sehen. ${ }^{57}$ Die ungarische Tracht gewann nach dem Gedenkmaterial - vermutlich wegen der oben dargelegten politischen Atmosphäre und der Repräsentationsabsicht - durch die Krönung Ferdinands III. Ende 1625 in Ödenburg eine Berechtigung auf den Medaillen und Jetons, die zur weltlichen Zeremonie der ungarischen Herrscherkrönung gehörten. Damit konnte das Bild des Königs in der Tracht des ungarischen Adels im breiten Kreis der am Ereignis beteiligten Untertanen popularisiert werden.

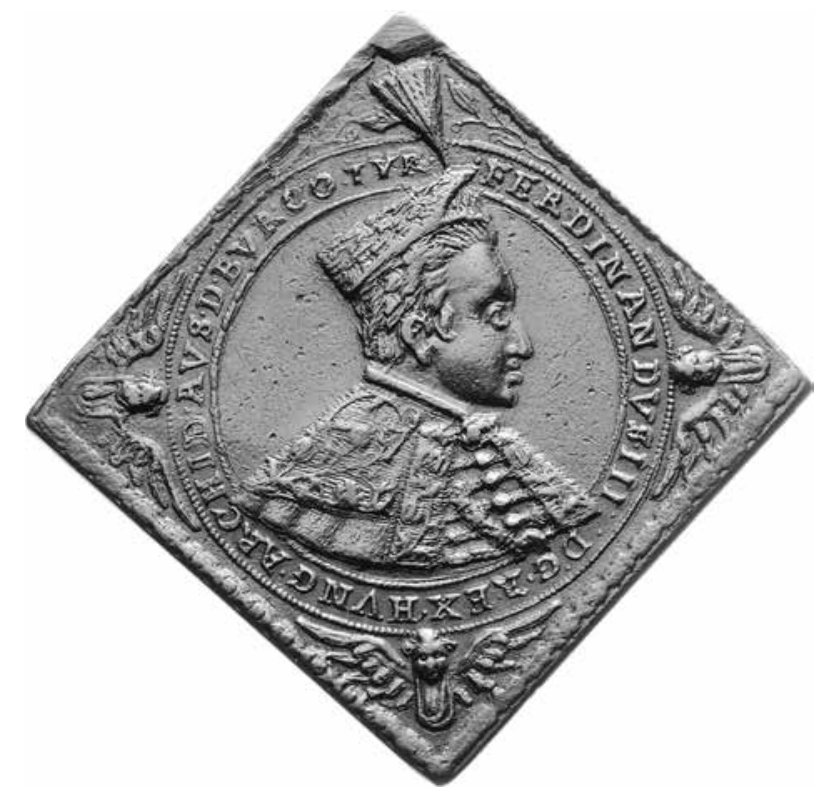

Abb. 17. Unbekannter Meister: Brustbild Ferdinands III. in ungarischer Tracht auf der Rückseite seiner Krönungs-Gedenkmedaille, o. J.; Budapest, MNM TKCs (Foto des Museums)

\section{DIE AUTHENTISCHE DARSTELLUNG DER UNGARISCHEN KRONE AUF SUSTERMANS' WERK}

Justus Sustermans' Darstellung ist vermutlich das erste offizielle Bildnis des jungen Herrschers. Es handelt sich um eine präzise und gleichsam in sich geschlossene Arbeit - zugleich ein vergeblicher Versuch des Malers, diesen jungen Mann mit dem sensiblen unreifen Gesicht, der die Flegeljahre kaum hinter sich hatte, als Herrscher dastehen zu lassen. Seine Verlegenheit konnte nämlich weder die königliche Krone noch der orientalische Pomp der vornehmen ungarischen Kleidung vergessen machen, der ihm Würde verlieh. Sein Äußeres als Herrscher ist auf dem Bild daher sehr relativ. Der Maler war ersichtlich nicht einmal bemüht, diese Verlegenheit zu verhüllen oder zu lösen. Die Erscheinung des Herrschers lockerte er weder mit einer Geste noch mit dem Anschein natürlichen Verhaltens, begleitet von einer ungezwungenen Haltung, auf. Es scheint, als hätte ein Blitzlicht den jungen ungarischen König auf diesem Bildnis in einer feierlichen und denkmalhaft unbeweglichen Pose erstarren lassen.

Das Porträt verdient einen außergewöhnlichen Platz in der Reihe der Darstellungen ungarischer Herrscher in dieser Epoche, und zwar nicht nur wegen seines ikonographischen Wertes, sondern auch wegen seiner Qualität. Die beiden können - wie so oft - auch diesmal nicht voneinander getrennt werden, denn die Sachlichkeit ungewöhnlichen Ausmaßes, mit der der Maler die gegenständlichen Details der kurz zuvor abgelaufenen Zeremonie darstellte, könnte sogar als Maßstab für die hohen Ansprüche eines Künstlers gelten. Zu diesen Details gehören nicht nur die prunkvolle Kleidung und das Schwert, sondern auch die königliche Krone auf dem Tisch, mit der er eine auch in den Details genau übereinstimmende Kopie des Originals liefert, auf eine - man muss sagen - in der damaligen Zeit außergewöhnliche Art und Weise (Abb. 18).

Auf die Frage der Wirklichkeitstreue der Darstellung der Heiligen Krone im 17. Jahrhundert sind mehrere Publikationen aus den vergangenen Jahren eingegangen. ${ }^{58}$ Eine der Ersten war die 1991 erschienene Version der gegenständlichen Studie, die neben der Aufzählung von Übereinstimmungen zwischen der Heiligen Krone und der Darstellung auf dem Gemälde auch einen analytischen Vergleich mit dem Kronenbild auf einem Stich von Kilian unternahm, ${ }^{59}$ der ein Jahrzehnt früher entstand, als Sustermans' Werk. Diesmal beschränke ich mich in Bezug auf den damaligen 


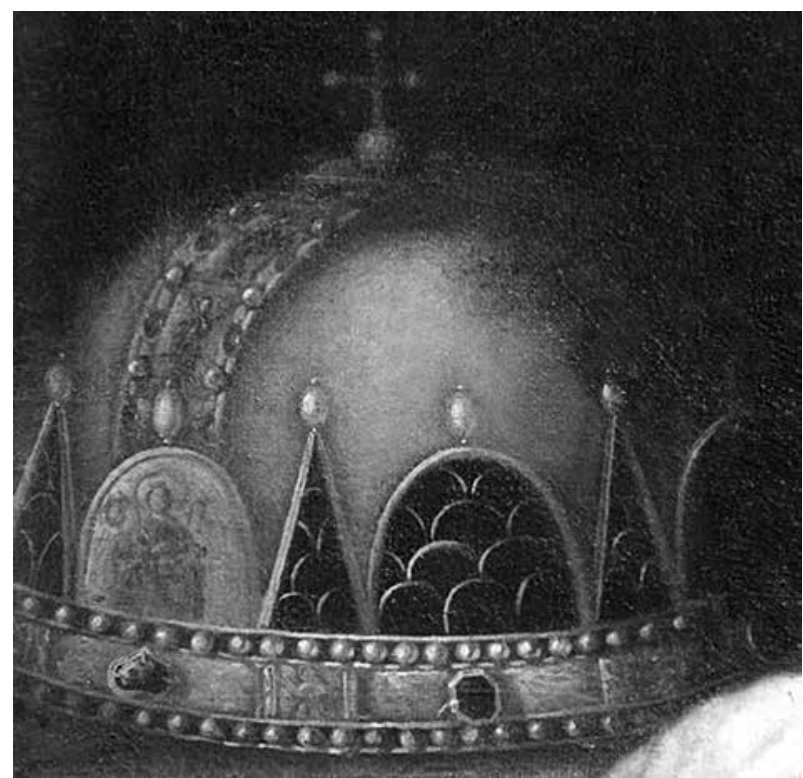

Abb. 18. Justus Sustermans und seine Werkstatt: Die ungarische Heilige Krone auf dem Bildnis Ferdinands III., 1626; Detail von Abb. 2 (Foto: Archiv der Verfasserin)

Inhalt lediglich auf die wiederholte Bekräftigung der Aussage, dass das originale Hoheitszeichen - in seiner gegenständlichen Realität sowie in den wichtigsten Details als Goldschmiedearbeit - die auf dem Bildnis festgehaltene Darstellung authentischer wiedergibt als Wolfgang Kilians in mehreren Versionen wiederholter Kupferstich, der im Kronentraktat von Péter Révay 1613 erschienen ist und als bildliche Quelle jahrzehntelang maßgeblich war ${ }^{60}$ (Abb. 19-20). Hierbei denke ich an wesentliche Abweichungen von der originalen Heiligen Krone: Anstatt der dunkelgrünen à jour Schuppenmusterverzierungen der halbrunden Aufsätze sind da Halbfiguren von St. Petrus mit dem Schlüssel in der Hand, der Christus links begleitet, rechts von ihm Apostel Philippus zu sehen, der das Kreuz hält, oder die Reihe der Medaillen-Porträts von Kaisern, die auf der Reifkrone, der sog. corona graeca, mit Lorbeerkranz und Brustharnisch gezeigt werden. Diese Reihe wird in der Mitte durch die Figur des mit dem Buch und dem Beil identifizierten Apostels Matthias unterbrochen - nach Révays Absicht als nachdrückliche Huldigungsgeste gegenüber dem damaligen ungarischen Herrscher, Matthias II. ${ }^{61}$

Die auf dem Ferdinand-Porträt gemalte Krone entspricht in diesen Details dem Original und ist gegenstandsgetreu auch in den sonstigen Momenten. Auf dem aus Vorderansicht dargestellten Hoheitszeichen können zum Beispiel die großformatigen Edelsteine auf dem Stirnreif gut identifiziert und die runden Flecken des Christus-Monogramms um die Figur

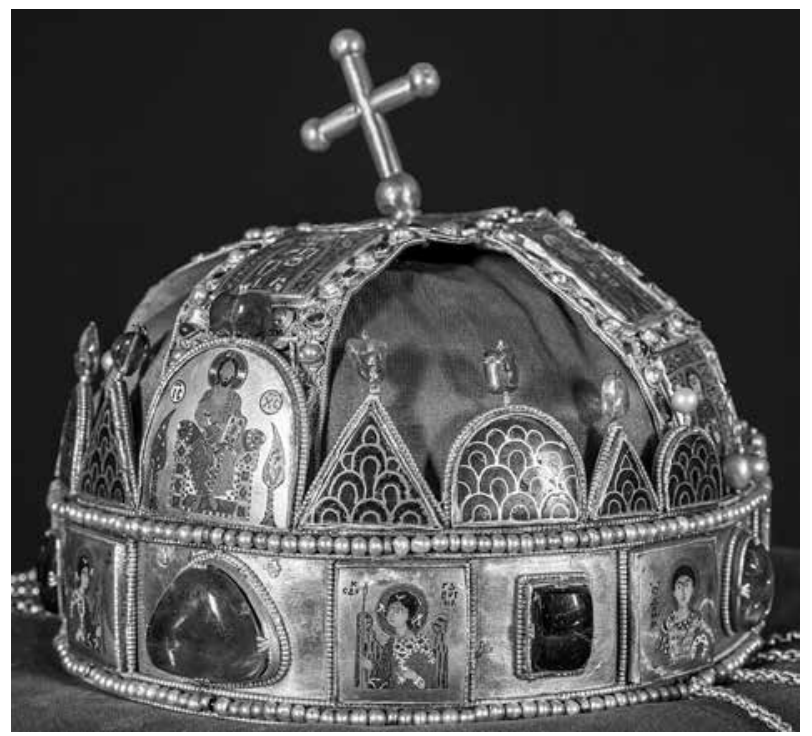

Abb. 19. Die ungarische Heilige Krone in Vorderansicht; Budapest, Parlament (Foto: György Bencze-Kovács)

des Pantokrators auf der mittleren Rundbogenplatte erkannt werden. Und eine weitere Beobachtung: Der Kreuzbügel der corona latina ist auf dem Bild länger, als in seiner heute bekannten Form, denn die beiden Apostelfiguren über der Pantokrator-Platte sind in voller Größe zu sehen. Die gemalte Darstellung untermauert auf diese Weise die bisher bekannten historischen Fakten ${ }^{62}$ hinsichtlich der Beschädigung der Kronenbügel 1638 und der etwa zu dieser Zeit erfolgten Umgestaltung der corona latina. Neben all dem ist das Hoheitszeichen auf dem Porträt in auffallendem Maße farbengetreu, was in der Literatur beziehungsweise in den Aufarbeitungen als Gesichtspunkt der Objekttreue beim Vergleich der Kronendarstellungen meistens verloren geht. Das Dunkelgrüne der Zierate mit dem Schuppenmuster, die wechselnde rote und weiße Farbe der Perlen und Edelsteine, die den Reif der corona latina umrahmen, aber auch die verwaschenen Farbtöne der Figuren der Zellenschmelzbilder erinnern an das Original. Genau diese Details, die den Farbengebrauch betreffen, sind als Informationen zu betrachten, die anhand von Stichen nicht vermittelt werden können. ${ }^{63}$ So kann man sich auf die erwähnten Entsprechungen verlassen und zu Recht behaupten, dass die auf dem Gemälde dargestellte Krone aufgrund der Kenntnis und des Anblicks des originalen Hoheitszeichens angefertigt wurde. Vielleicht ist es mit der Platzierung auf einem Kissen oder - wie dies bei einem Teil der Krönungszeremonie üblich war - auf einer Schmuckschale ${ }^{64}$ zu erklären, dass die in einem solchen Fall seitlich liegenden Pendilien der Krone auf dem Bild - von 


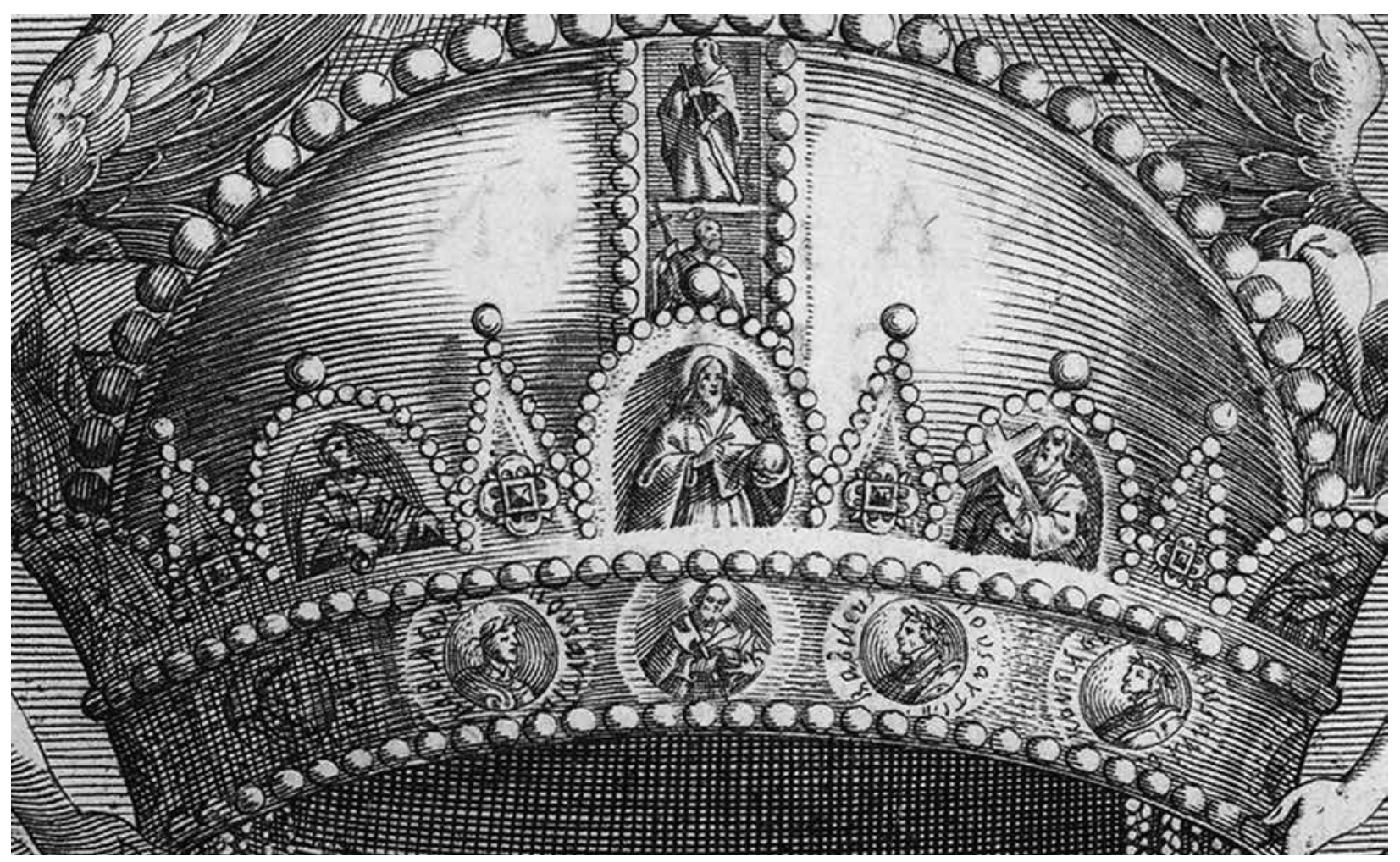

Abb. 20. Wolfgang Kilian (1581-1662): Die ungarische Heilige Krone in Péter RÉVAY: De Sacrae Coronae Regni Hungariae..., 1613; Detail; Budapest, OSZK RMNy (Foto der Bibliothek)

Ferdinands Hand verdeckt - nicht zu sehen sind. Das „Fehlen“ der Pendilien ist also eine Folge der situationsgetreuen Darstellung.

Bei einer offiziellen Bestellung ist es ein fast in Verlegenheit bringender Anspruch seitens eines damaligen Malers, der gegenständlichen Authentizität in einem so hohen Maße Genüge leisten zu wollen insbesondere, wenn wir beachten, dass die Krone als nicht „öffentlicher" Gegenstand lediglich bei Krönungen zu sehen und zugänglich war, vermutlich auch für den Maler. Obwohl der Krone auf den Krönungsbanketten nach dem seit 1608 ausführlich geregelten Zeremoniell auch ein Platz eingeräumt war, damit die Anwesenden sie sich ansehen konnten, ${ }^{65}$ dürfte dies für den Maler dennoch nicht die einzige Gelegenheit einer gründlichen Betrachtung und der Anfertigung einer zum Gemälde erforderlichen Skizze gewesen sein. Da es sich um einen offiziellen Auftrag handelte, hatte der Maler in den zwei Wochen - vom 30. November bis zum 14. Dezember -, als sich die Krone in Ödenburg befand, mit großer Wahrscheinlichkeit die Möglichkeit, das Hoheitszeichen, das im Quartier der Herrscherfamilie aufbewahrt war, in Augenschein zu nehmen und zu kopieren. ${ }^{66}$

Der offizielle Charakter der Aufgabe und die damit einhergehende Möglichkeit werden durch das vermutete erste Exemplar der Komposition, durch die eigenhändige, für die Herrscherfamilie zu Repräsentationszwecken gefertigte Version untermauert. Des Weiteren gibt es keine Information mehr über das Bild, doch Wolfgang Kilians Kupferstich über Ferdinand III. im ungarischen Krönungsornat entstand 1629 aller Gewissheit nach auf dieser Grundlage (Abb. 3). Das einstige Vorhandensein einer ersten Fassung in Wien wird außer durch das Kilian-Blatt auch durch die von der Sustermans-Komposition gemalte farbengleiche Kopie aus dem 18. Jahrhundert bestätigt, die Lajos Ernst für seine historische Sammlung erwarb und die letztlich in die Historische Bildergalerie des Nationalmuseums gelangte. ${ }^{67}$ 


\section{SAMMLUNGSHISTORISCHE FRAGEN DES PORTRÄTS VON FERDINAND III. - DIE LEGANÉS-SAMMLUNG}

Das Exemplar des Sustermans-Porträts in der Ungarischen Nationalgalerie wurde 1637 bereits im Besitz von Diego Mexía Felipez de Guzmán, Marquis Leganés (1580-1655) dokumentiert. Danach wird es in den Sammlungsinventaren von 1642 beziehungsweise 1655 angeführt, in beiden Fällen unter Nr. 475, die unten auf der Draperie zur Abdeckung des Tisches auf dem Porträt auch heute noch zu lesen ist - in der Nähe eines bisher noch nicht gelösten späteren Sammlungszeichens (45.V.M). Die beim Ableben des Marquis in Madrid aufgenommene Zusammenstellung aus dem Jahr 1655, die auch den Wert und die zur Identifikation geeignete kurze Beschreibung beinhaltet, erwähnt das Bild, ohne den Maler zu nennen. ${ }^{68}$ Der nächste Posten im Inventar ist ein vorläufig nicht bekanntes Bildnis „der ungarischen Königin“. In Zusammenhang mit ihm ist nicht auszuschließen, dass es ein nachträglich gemaltes Paarstück des Ferdinand-Porträts war. ${ }^{69}$

Marquis Leganés war Verwandter und Schützling vom Grafen Olivares (1587-1645), dem ersten Minister des spanischen Königs Philipp IV. (1621-1665), einer der namhaftesten spanischen Kunstsammler seiner Zeit, den der König 1627 als Höfling von bedeutender Position in den Adelsstand erhob. ${ }^{70}$ Seine Galerie enthielt nach dem Nachlassinventar vom Jahr 1655 1333 Werken, zumeist von flämischen Meistern aus dem 17. Jahrhundert. Damit war sie in diesem Bereich in Spanien eine der angesehensten Bildergalerien seiner Epoche, vergleichbar damals lediglich mit der königlichen Sammlung. ${ }^{71}$ Obwohl die Qualität der Kollektion nach Meinung der Forscher ziemlich schwankte, waren die namhafteren zeitgenössischen flämischen Maler - Anthonis van Dyck, Jacob Jordaens, Gaspar de Crayer, Jan Brueghel, Gerard Seghers, Frans Snyders, Paul de Vos und Peeter Snayers - mit mehr als zehn Arbeiten vertreten, während der Marquis mehr als 30 Arbeiten von Rubens sein Eigen nennen konnte, den er aufrichtig bewunderte..$^{72}$

Im Interesse Leganés' und in der Entwicklung des Charakters seiner Sammlung war es von entscheidender Bedeutung, dass der Marquis schon in seinen jungen Jahren am Brüsseler Hof der spanischen Infantin Isabella Clara Eugenia (1566-1633), später Statthalterin in den spanischen Niederlanden (1622-1633), seinen Dienst leistete, dann zwischen 1630 und 1635 ebenfalls dort als Oberkommandierender der spanischen Truppen residierte. ${ }^{73}$ Sein Interesse für die Künstler und die Bilder ist jedoch früheren Ursprungs.
Seine Freundschaft mit Rubens kann bereits von 1625 an nachgewiesen werden. Vermutlich kann auch der Beginn seiner Kunstförderung und -sammlung - als gesellschaftlich würdige Tätigkeit - auf diese Zeit datiert werden. ${ }^{74}$ Auf dem um 1627 gemalten Gesellschaftsbild von Willem van Haecht, das Erzherzogin Isabella im Kreis ihrer Hofmitglieder im Galerieraum verewigt, ist Leganés auf jeden Fall unter den Sammlern und Kunstgenießern zu sehen. ${ }^{75}$ Rubens nannte ihn in einem seiner Briefe aus dem Jahr 1628 zu Recht einen der herausragendsten „connaisseur" seiner Zeit. ${ }^{76}$

Eines der besonderen Merkmale seiner Sammlung bestand in Leganés' erhöhtem Interesse für Porträts. In den 1630 bzw. 1642 in seinem Madrider Haus aufgenommenen Inventaren werden fast ausnahmslos Bildnisse der bedeutendsten - teilweise zeitgenössischen Vertreter der europäischen Porträtmalerei wie Rubens, Van Dyck, Ribera und Velázquez ${ }^{77}$ erwähnt, deren angeführte Arbeiten Mitglieder der europäischen Herrscherhäuser und Hauptakteure der politischen oder militärischen Elite zeigten. Der Marquis wurde ersichtlich auch später beim Erwerb der Bildnisse in auffälliger Menge von diesem Aspekt geleitet, denn bei der Inventaraufnahme seiner Sammlung im Jahr 1655 wurden unter den 1333 Gemälden 358 Porträts registriert, darunter verewigten 248 Bilder Mitglieder von Herrscherhäusern und führenden spanischen Aristokratenfamilien sowie Prominente der katholischen Kirche und der Militärführung. ${ }^{78}$ Dadurch schuf der Marquis mit den Porträts der Notabilitäten des damaligen Europas eine Art "gesellschaftliche Galerie" mit dem typischen Bestreben jener, die mit einer schnellen Karriere auf den Rang von Adeligen erhoben, ihr neues gesellschaftliches Umfeld in effigie um sich herum darstellten. Das wird auch durch die Beobachtung Mary Crawford-Volks untermauert, die die Geschichte der Sammlung bearbeitete, wonach der Marquis vor allem die Porträts von Personen erwarb, zu denen er ausgesprochen loyal war. Unter ihnen sollten in erster Linie Mitglieder des Madrider Hofes und der königlichen Familie sowie Personen verstanden werden, die mit ihnen verwandt waren oder in enger Beziehung zu ihnen standen. ${ }^{79}$

In den Quellen, die über die Ödenburger Krönung berichten, kommt der Name von Leganés nach unseren bisherigen Kenntnissen nicht vor. So kann man nicht wissen, ob er als Mitglied der spanischen Delegation beim Ereignis persönlich zugegen war. ${ }^{80}$ Auf 
jeden Fall war er an den offiziellen Aufgaben in Bezug auf den Ehevertrag zwischen dem jungen Herrscher und der Infantin beteiligt. Dementsprechend spricht Franz Christoph Khevenhiller über ihn als Anwesenden bei der offiziellen Verkündung der Absicht der Verehelichung, zu der es nach der ungarischen Krönung, am 18. Juni 1626, dem Dreifaltigkeitstag, in Madrid kam. ${ }^{81}$

Über Leganés' Sammlung und seine Sammeltätigkeit ist vor Kurzem eine gründliche Monographie entstanden, ${ }^{82}$ die auch die Inventarangaben der Werke eingehend aufarbeitet. Sie hilft uns trotz der reichlichen Erwerbsinformationen bezüglich der einzelnen Sammlungsstücke jedoch nicht dabei, Klarheit über die Rolle des Marquis bei der Entstehungs- und Sammlungsgeschichte des Porträts von Ferdinand III. zu gewinnen. Das erste, zum Teil unnummerierte Inventar über die im Madrider Palais aufbewahrten Stücke der Sammlung wurde 1630, zur Gründung des familiären Fideikommisses (mayorazgo) aufgenommen. ${ }^{83}$ Das nächste Verzeichnis, das bereits nummerierte Posten enthielt, wurde 1637, nach dem Tod Leganés' erster Gattin zwecks Schätzung des Wertes zusammengestellt. ${ }^{84}$ Während das letzte, zu Lebzeiten des Marquis aufgenommene Inventar mit dem Datum 1642 aus der Zeit nach der Mailänder Regentschaft (1635-1641) stammt. ${ }^{85} \mathrm{Ihm}$ folgt das bereits erwähnte vollständigste Inventar aus dem Jahr 1655.

Wie der Monograph feststellte, halten die nummerierten Verzeichnisse $(1637,1642,1655)$ die Werke in übereinstimmender Reihenfolge fest; ihre Positionsnummern sind ebenfalls identisch, sodass auf dieser Grundlage auch das Datum eingegrenzt werden kann, wann die Bilder in die Sammlung kamen. ${ }^{86}$ Bei alldem geht aus dem Katalogteil der Monographie auch die Ordnung der einzelnen Bestandsaufnahmen gut hervor. Demnach sind in der Konskription im Jahr 1630 die Werke (laut der späteren Inventarlisten) mit den Posten von 1 bis 40 nicht nummeriert, Postennummern sind nur zwischen 331 und 702 zu finden. Die Bilder sind allerdings nur bis zum Posten 40 in beiden früheren Inventaren (1630 und 1637) enthalten. Jene zwischen 40 und 331 fehlen im Inventar des Jahres 1630, sie kommen nur im Verzeichnis aus dem Jahr 1637 vor. Die Bilder mit den Nummern zwischen 331 und 702 wurden abwechselnd registriert, d. h. immer nur in einem der beiden Inventare. Die Nummerierung der Posten ist zugleich laufend und stimmt mit den Inventarnummern der späteren Verzeichnisse (1642 und 1655) überein. ${ }^{87}$ Also gab es vom Beginn der Registrierung der Sammlung an eine fortlaufende
Zahlenreihe, unabhängig davon, in welchem Inventar ein Werk eingetragen wurde.

Aus obigen Umständen kann man hinsichtlich des unter Nr. 475 in der Sammlung inventarisierten Porträts von Ferdinand III. sowie des Bildnisses seiner Gattin, Nr. 476, die Schlussfolgerung ziehen, dass es aufgrund der fortlaufenden Nummerierung eigentlich keine Bedeutung hat, dass Ferdinands Bildnis lediglich im Verzeichnis des Jahres 1637 enthalten ist, wenn das Porträt seiner Gattin, der Königin Maria Anna, unter der nächsten (!) Inventarnummer bereits 1630 ins Inventar aufgenommen wurde. Die Nummer 475 des Porträts des Herrschers ist auch im Jahr 1630 „nicht besetzt", lediglich nicht eingetragen im Inventar. Etwas Sicheres können wir freilich nicht behaupten. Aufgrund der Daten und der Methode der Inventur besteht allerdings die hohe Wahrscheinlichkeit, dass Leganés das Bildnis von Ferdinand III. schon vor 1630 erworben hatte. ${ }^{88}$

Obwohl wir in Kenntnis der einschlägigen Ergebnisse der Sammlungsverarbeitung keinen sicheren Anhaltspunkt dafür haben, dass das Porträt in der Ungarischen Nationalgalerie von Sustermans für Leganés gemalt worden ist, stellen die bisherigen Kenntnisse dies nicht in Frage. Das Porträt - entweder dieses Exemplar oder die ihm als Vorbild dienende Erstfassung - entstand nämlich laut Inschrift auf der Rückseite im Januar 1626. ${ }^{89}$ Das kann wegen des Lesbarkeitsproblems der durch das Dublierleinen durchschimmernden Inschrift gegenwärtig nicht festgestellt werden. Von der Mehrheit der Statusporträts - angefertigt im Allgemeinen durch Mitwirkung von Gehilfen - entstand nicht nur ein einziges Exemplar, wie ich dies auch im Fall des Krönungsporträts Ferdinands III. vermute..$^{90}$ Man muss mit dem Vorhandensein von mindestens einer ersten Version rechnen, die - wie oben bereits erwähnt - dem Kupferstecher Wolfgang Kilian als Vorbild für den ersten „offiziellen“ Porträtstich des jungen Herrschers (Abb. 3) sowie für die im 18. Jahrhundert gemalte Kopie zur Verfügung stand und die demzufolge im Besitz der Herrscherfamilie gewesen sein musste.

Da wir außer dem Porträt von Ferdinand III. vorläufig kein anderes Werk beziehungsweise keinen sonstigen Beweggrund mit dem Besuch Sustermans' in Wien verbinden können, der auf Ende 1625 datiert werden kann, ist anzunehmen, dass sein Wiener Aufenthalt kurz und gelegentlich war. Danach war er unter Beteiligung seiner Gehilfen bereits in seiner Werkstatt in Florenz den eventuellen nachträglichen Aufträgen nachgekommen. ${ }^{91}$ Auf diese Weise sollten wir die 
Bestellung nicht unbedingt auf eine Person fokussieren, die am Ereignis teilnahm oder ihren Dienst in Wien leistete. Die auf der Hand liegende Möglichkeit, dass eine der Fassungen des Porträts für den spanischen Gesandten in Wien, Francisco de Moncada, Marquis Aytona (1624-1629), ${ }^{92}$ oder eventuell für ein Mitglied seines Umfeldes gefertigt wurde und von ihm auf irgendeinem Weg in Leganés' Sammlung gelangte, würde nicht weniger Fragen aufwerfen, als die bisherigen. Und zwar insbesondere deshalb, weil Marquis Aytona laut des Monographen über keine erwähnenswerte Sammlung verfügte. Preciado weiß lediglich von einem durch Leganés erworbenen Bildnis, von Van Dycks Porträt des Marquis Aytona, das der Sammler 1634 während ihres Treffens in Brüssel von Aytona gekauft hatte..$^{93}$

Sustermans, den Cosimo Medici um 1620 in seinen Dienst nahm, wirkte sechzig Jahre lang als Porträtmaler am Hof in Florenz. Die Popularität und der damalige Ruf des Malers, der drei Generationen der Medicis, das nähere und breitere Umfeld ihres Hofes verewigte, werden durch nichts besser bestätigt, als durch Einladungen von den teils mit den Medicis verwandten fürstlichen Familien, denen er während seiner Laufbahn durch sein Wirken an den Höfen von Mantua, Parma, Piacenza, Modena, Genua und Ferrara folgte. Ferner wissen wir von seinem Aufenthalt um
1640 in Mailand, als er für Leganés arbeitete, der dort als Statthalter residierte. ${ }^{94}$ Den Anlass seiner ersten Reise zum Habsburger Hof lieferte die Möglichkeit, als er das Brautporträt der künftigen Gattin Ferdinands II., der Erzherzogin Eleonore Anna von Gonzaga aus Mantua, im Jahr 1622 persönlich dem Kaiser in Wien präsentierte. Daraufhin verewigte er im Laufe seines mehr als ein Jahr währenden Aufenthaltes in Wien - von 1623 bis Oktober 1624 - mehrere Mitglieder der Kaiserfamilie. Den Erzherzog Ferdinand, damals noch im Kindesalter, malte er zu dieser Zeit das erste Mal. ${ }^{95}$ Aus späteren Zeiten wissen wir nur noch von einer Reise von ihm nach Rom, die er auf Einladung des Papstes Urban VIII. (1623-1644) 1627 unternahm. ${ }^{96}$

Aufgrund des Bildnisses des ungarischen Königs Ferdinand III. können wir zu Recht annehmen, dass Sustermans Ende 1625 erneut in Wien weilte und daher die Gelegenheit gehabt hätte, an der Krönung teilzunehmen. Allein zu dieser Zeit hätte er nämlich - und wie oben beschrieben, müsste er sogar - die ungarische Heilige Krone gesehen haben, die er auf dem Porträt des jungen Herrschers - mit einer Ambition, die die Praxis seiner Epoche weit übertraf - so authentisch darstellte. Die genaue Kenntnis der ungarischen Krone bzw. der aus Quellen bekannten Details der Krönungstracht bestätigt, dass er beim Zeremoniell in Ödenburg anwesend war.

\section{ABKÜRZUNGEN}

\section{Institutionen}

KHM

MNG RMGy

MNM TKCs

OSZK RMNy

ÖNB
Kunsthistorisches Museum, Wien

Magyar Nemzeti Galéria, Régi Magyar Gyújtemény / Ungarische Nationalgalerie, Sammlung Alte Kunst, Budapest

Magyar Nemzeti Múzeum, Történelmi Képcsarnok / Ungarisches Nationalmuseum, Historische Bildergalerie, Budapest

Országos Széchényi Könyvtár, Régi Nyomtatványok Tára / Széchényi Nationalbibliothek, Abteilung der Alten Drucke, Budapest

Österreichische Nationalbibliothek, Wien

\section{LITERATUR}

A korona kilenc évszázada 1979 - A korona kilenc évszázada. Történelmi források a magyar koronáról [Die neun Jahrhunderte der Krone. Historische Quellen über die ungarische Krone], hrsg. von Katona, Tamás, Budapest, 1979. (Bibliotheca Historica)

A koronázási jelvények okmányai 2002 - A koronázási jelvények okmányai [Zur frühneuzeitlichen Geschichte der Krönungsinsignien], hrsg. von SzviteK, Róbert József TótH, Endre, Budapest, 2002. (Bibliotheca Humanitatis Historica XVIII.)
Ács 2010 - Ács, Pál: „Pro Turcis” és „contra Turcos”. Kuriozitás, tudomány és spiritualizmus Johannes Löwenklau (1541-1594) török históriájában ["Pro Turcis" and "contra Turcos". Curiosity, Scholarship and Spiritualism in Turkish Histories by Johannes Löwenklau (1541-1594)], in „Ez világ, mint egy kert...” Tanulmányok Galavics Géza tiszteletére [„Diese Welt wie ein Garten..."Festschrift für Géza Galavics], hrsg. von BubrYÁk, Orsolya, Budapest, 2010. 79-94. 
An der Heiden 1970 - An der Heiden, Rüdiger: Die Porträtmalerei des Hans von Aachen, Jahrbuch der Kunsthistorischen Sammlungen in Wien 66. 1970. 135-226.

Arroyo Martin 2017 - Arroyo Martin, Francisco: El marqués de Leganés. El favorito del valido, Madrid, 2017.

Artisti alla corte granducale 1969 - Artisti alla corte granducale. A cura di Chiarini, Marco. Catalogo mostra, Palazzo Pitti, Firenze, 1969.

Az 1625. évi soproni koronázó országgyũlés 2018 - Az 1625. évi soproni koronázó országgyúlés [Der ungarische Krönungsreichstag in Ödenburg 1625 / The Hungarian Diet and Coronation at Sopron in 1625], hrsg. von Dominkovits, Péter - Katona, Csaba - PÁlfFy, Géza, Magyar Nemzeti Levéltár Gyôr-Moson-Sopron Megye Soproni Levéltára - MTA Bölcsészettudományi Kutatóközpont Történettudományi Intézet, Sopron-Budapest, 2018. (Annales Archivi Soproniensis 2.) (In Vorbereitung)

BAGI 2011-2013 - BAGI, Zoltán Péter: Das Türkenbild der kaiserlichen Propositionen, die Reichstage und die Türkensteuer während des Langen Türkenkrieges, UngarnJahrbuch 31. 2011-2013. 119-138.

BALIS 1985 - BALIS, Arnout: Mécénat espagnol et art flamand au XVII siècle, in Splendeurs d'Espagne et les villes belges 1500-1700, Exposition, Bruxelles, Palais des BeauxArts, Bruxelles, 1985. 283-296.

Baroque Art in Central Europe 1993 - Baroque Art in Central Europe. Crossroads, Exh. cat., ed. Galavics, Géza, Budapesti Történeti Múzeum, Budapest, 1993.

BaUtier 1912 - Bautier, Pierre: Juste Suttermans, peintre des Medicis, Bruxelles-Paris, 1912.

BENDA-FüGEDI 1979 - BENDA, Kálmán - FüGEdi, Erik: A magyar korona regénye [Roman der ungarischen Krone], Budapest, 1979.

Berning 2008 - Berning, Benita: „Nach alltem löblichen Gebrauch“. Die böhmischen Königskrönungen der Frühen Neuzeit (1526-1743), Köln-Wien, 2008. (Stuttgarter Historische Forschungen 6.)

BERTÉNYI 2001 - BerTÉNYI, Iván: Révay Péter Magyarország Szent Koronájáról írt munkájának forrásértéke (Quellenwert des Aufsatzes von Péter Révay über die Heilige Krone), in A történelem és a jog határán. Tanulmányok Kállay István születésének 70. évfordulójára [An der Grenze zwischen Geschichte und Recht. Beiträge zum 70. Geburtstag von István Kállay], hrsg. von SEIFERT, Tibor. Budapest, 2001. 19-28.

Bónis 1981 - BónIS, György: Révay Péter, Budapest, 1981. (Irodalomtörténeti Füzetek 104.)

Broucek 1986 - Broucek, Peter: Im Kampf gegen Franzosen und Türken, in Welt des Barock, Ausstellungskatalog, Chorherrenstift St. Florian, hrsg. von FeuchTMÜlLER, Rudolf - KováCS, Elisabeth, Linz, 1986. Bd. I. 105-122.

BuZÁsI 1991 - BuZÁsI, Enikő: III. Ferdinánd mint magyar király (Justus Sustermans ismeretlen múve az egykori Leganés gyüjteményből) [Ferdinand III. als ungarischer König (Ein unbekanntes Werk von Justus Sustermans aus der einstigen Sammlung Leganés)], A Magyar Nemzeti Galéria Évkönyve / Annales de la Galerie Nationale Hongroise - Müvészettörténeti tanulmányok Mojzer Miklós hatvanadik születésnapjára / Etudes sur l'histoire de l'art en honneur du soixantième anniversaire de Miklós Mojzer, hrsg. von BuZÁsI, Enikô - JÁvor, Anna - Mikó, Árpád TAKÁCS, Imre, Budapest, 1991. 149-158.
BuZÁSI 2009 - BuZÁsI, Enikô: Justus Sustermans et son atelier - Ferdinand III en roi de Hongrie, 1626, in „Plus vrai que nature". Robert Campin et le portrait "flamand“, Exposition temporaire, Musée des Beaux-Arts de Tournai, Tournai, 2009. 13-15.

BuZÁSI 2011 - BUZÁSI, Enikô: Portrésorozatok a 17. századi magyar arisztokraták politikai reprezentációjában [Portrait series in the political representation of the hungarian aristocracy in the 17th century], Múvészettörténeti Értesitô 60. 2011. 11-21.

BuZÁSI-PÁlfFy 2014 - BuZÁsi, Enikô - PÁlfFy, Géza: A magyar korona eddig ismert legkorábbi autentikus ábrázolásának keletkezésérôl. A Szent Korona a Habsburg Ehrenspiegelben [The origin of the earliest known authentic representation of the Hungarian Crown. The Holy Crown of Hungary in the Habsburg Ehrenspiegel], Müvészettörténeti Értesítô 63. 2014. 217-264.

BuZÁsi-PÁlfFy 2015 - BuZÁsi, Enikő - PÁlfFy, Géza: Augsburg-Wien-München-Innsbruck. Die frühesten Darstellungen der Stephanskrone und die Entstehung der Exemplare des Ehrenspiegels des Hauses Österreich. Gelehrten- und Künstlerbeziehungen in Mitteleuropa in der zweiten Hälfte des 16. Jahrhunderts, Budapest, 2015.

BÜCHEL 1925 - BÜCHEL, Johann Baptist: Bilder aus der Geschichte des Fürstenhauses von und zu Liechtenstein, Jahrbuch des Historischen Vereins für das Fürstentum Liechtenstein 25. 1925. 9-115.

CARAFFa 1628 (1860) - Carlo CarafFa Vescovo d'Anversa: Relatione dello stato dell'imperio e della Germania fatta dopo il ritorno della sua nuntiatura appresso l'imperatore. 1628, hrsg. von MülLER, Joseph Godehard, Archiv für Kunde österreichischer Geschichts-Quellen 23. 1860. 101-450.

ChIARINI 1984 - ChIARINI, Marco: Giusto Sustermans: il Giuramento di fedeltà del senato fiorentino a Ferdinando II de' Medici, Bollettino d'arte 69. 1984/25. 77-84.

Coronatio Hungarica in Nummis 2016 - Coronatio Hungarica in Nummis. A magyar uralkodók koronázási érmei és zsetonjai (1508-1916) [Krönungsmedaillen und Jetons der ungarischen Herrscher], hrsg. von BERTók, Krisztina, Budapest, 2016.

Crawford-Volk 1980 - Crawford-Volk, Mary: New Light on a Seventeenth-Century Collector: The Marquis of Leganés, The Art Bulletin 62. 1980/2. 256-268.

CRINO 1955 - CRINÒ, Anna Maria: Contributo allo studio dell'attivitá del Giusto Sutterman, Rivista d'Arte 30. 1955. 217-228.

Die Gemäldegalerie des Kunsthistorischen Museums in Wien 1991 - Die Gemäldegalerie des Kunsthistorischen Museums in Wien, Verf. Ferino-Pagden, Sylvia - Prohaska, Wolfgang - SCHÜTZ, Karl, Wien, 1991.

Diepenbroick-Grüter 1967 - DiePenbroick-Grüter, HansDietrich von: Allgemeiner Porträtkatalog, Hildesheim, 1967.

F. DÓzsA 2001 - F. DózsA, Katalin: Die ungarische Nationaltracht als Hofkleidung, in Kaiser und König 1526-1918. Eine historische Reise: Österreich und Ungarn, Ausstellungskatalog, Collegium Hungaricum - Österreichische Nationalbibliothek, hrsg. von FAZEKAS, István UjVÁRY, Gábor, Wien-Budapest, 2001. 23-28.

Egy új együttmüködés kezdete 2014 - Egy új együttmüködés kezdete. Az 1622. évi soproni koronázó országgyülés [Anfang 
einer neuen Kooperation. Der ungarische Krönungsreichstag in Ödenburg 1622], hrsg. von DominkoviTs, Péter - Katona, Csaba, Sopron-Budapest, 2014. (Annales Archivi Soproniensis 1.).

FraKNói 1868-1872 - FrankL [FraKNói] Vilmos: Pázmány Péter és kora [Péter Pázmány und seine Zeit] Bd. I-III, Pest, 1868-1872.

FRAKNÓI 1921 - FRAKNói Vilmos: A magyar királyválasztások története [Die Geschichte der ungarischen Königswahlen], Budapest, 1921.

FuČíKOVÁ 2010 - FuČíKOVÁ, Eliška: Das Leben, in Hans von Aachen (1552-1615) Hofkünstler in Europa, hrsg. von FUSENIG, Thomas, Ausstellungskatalog, SuermondtLudwig-Museum Aachen - Kunsthistorisches Museum Wien - Prager Burg, Aachen-München, 2010. 3-11.

Galavics 1986 - Galavics, Géza: „Kössünk kardot az pogány ellen”. Török háborúk és képzômüvészet [„Lasset uns umgürten mit dem Schwert gegen die Heiden“. Türkenkriege und bildende Kunst], Budapest, 1986.

Galavics 1993 - Galavics, Géza: Netherlandish Baroque Painters and Graphic Artists in 17th-Century Central Europe, in Baroque Art in Central Europe. Crossroads, Exh. cat., ed. Galavics, Géza, Budapesti Történeti Múzeum, Budapest, 1993. 83-106.

GALAVICS 2001 - GALAVICS, Géza: Die künstlerische Repräsentation der Habsburger-Könige bis 1848, in Kaiser und König 1526-1918. Eine historische Reise: Österreich und Ungarn, Ausstellungskatalog, Collegium Hungaricum Österreichische Nationalbibliothek, hrsg. von FAZEKAS, István - UjváRY, Gábor, Wien-Budapest, 2001. 9-18.

GONDA-NiEDERHAUSER 1977 - GONDA, Imre - NiEDERHAUSER, Emil: A Habsburgok. Egy európai jelenség [Die Habsburger. Ein europäisches Phänomen], Budapest, 1977.

Hammer-Purgstall 1845 - Hammer-Purgstall, Joseph Frh. von: Über die Verhandlungen mit Herrn von Rosenberg während des Einfalls des Passau'schen Kriegsvolkes in Böhmen i. J. 1611, in Abhandlungen der Königlichen Böhmischen Gesellschaft der Wissenschaften von den Jahren 1843-1844. 5. Folge, Bd. III. Prag, 1845.

Hans von Aachen (1552-1615) Hofkünstler in Europa 2010 - Hans von Aachen (1552-1615) Hofkünstler in Europa, hrsg. von Fusenig, Thomas, Ausstellungskatalog, Suermondt-Ludwig-Museum Aachen - Kunsthistorisches Museum Wien - Prager Burg, Aachen-München, 2010.

Heinz 1963 - Heinz, Günther: Studien zur Porträtmalerei an den Höfen der österreichischen Erblande, Jahrbuch der Kunsthistorischen Sammlungen in Wien 59. 1963. 99-224.

HeInZ-Schütz 1976 - HeInZ, Günther - Schütz, Karl: Porträtgalerie zur Geschichte Österreichs von 1400 bis 1800, Wien, 1976.

Hengerer 2012 - Hengerer, Mark: Kaiser Ferdinand III. (1608-1657). Eine Biographie, Wien-Köln-Weimar, 2012.

Hiller 1989 - Hiller István: Magyar nádorválasztás és európai politika. Az 1625. évi soproni országgyưlés nemzetközi diplomáciai vonatkozásai [Die Wahl eines Palatins und die europäische Politik. Die internationalen diplomatischen Beziehungen des Landtages in Ödenburg vom Jahre 1625], Soproni Szemle 43. 1989. 59-70.

Hiller 1993 - Hiller István: „Sopronból azt írhatom Méltóságodnak..." Külföldi diplomaták az 1625. évi sopro- ni országgyúlésen [,Ich kann aus Ödenburg für Euer Hochgeboren schreiben...". Ausländische Diplomaten am Landtag von Ödenburg im Jahr 1625], in Házi Jenô Emlékkönyv, hrsg. von Dominkovits, Péter - Turbuly, Éva. Sopron, 1993. 255-266.

Hiller 2001 - Hiller, István: Die Habsburgerdiplomatie und das Königliche Ungarn. Gesandte und Gesandtschaften im 16.-17. Jahrhundert, in Kaiser und König 1526-1918. Eine historische Reise: Österreich und Ungarn, Ausstellungskatalog, Collegium Hungaricum - Österreichische Nationalbibliothek, hrsg. von FAzEKAS, István - UjvÁRY, Gábor, Wien-Budapest, 2001. 47-49.

Holl 1980 - Holl Béla: Ferenczffy Lórinc. Egy magyar könyvkiadó a XVII. században [Laurentius Ferenczffy. Ein ungarischer Verleger im 17. Jahrhundert], Budapest, 1980.

JACOBY 2000 - JACOBY, Joachim: Hans von Aachen 1552-1615, München-Berlin, 2000.

Kaiser und König 2001 - Kaiser und König 1526-1918. Eine historische Reise: Österreich und Ungarn, Ausstellungskatalog, Collegium Hungaricum - Österreichische Nationalbibliothek, hrsg. von FAZEKAS, István - UjváRY, Gábor, Wien-Budapest, 2001.

Khevenhiller 1724 - Khevenhiller, Franz Christoph: Annales Ferdinandei Oder Wahrhaffte Beschreibung Kaysers Ferdinandi des Andern ... Thaten Bd. X, Leipzig, 1724.

KovÁcs 1986 - Kovács, Elisabeth: Die Apotheose des Hauses Österreich. Repräsentation und politischer Anspruch, in Welt des Barock I-II, Ausstellungskatalog, Chorherrenstift St. Florian, hrsg. von FEUCHTMÜLlER, Rudolf - Kovács, Elisabeth, Linz, 1986. Bd. I. 53-86.

KÖHBACH 1999 - KÖHBACH, Markus: Çasar vagy imperator? A római császárok oszmánok által használt megszólításairól a zsitvatoroki békét követóen [Çasar oder Imperator? Zur Titulatur der römischen Kaiser durch die Osmanen nach dem Vertrag von Zsitvatorok (1606)], Aetas 14. 1999/4. 177-183.

Kuster 2011-2012 - Kuster, Thomas: „.. den Neidern und Feinden des habsburgischen Namens und Ruhmes zum Trotze und Spotte..." Der Habsburger Pfau - ein kurioser Wappenträger, Jahrbuch des Kunsthistorischen Museums Wien 13-14. 2011-2012. 76-103.

LugT 1953 - LugT, Frits: Répertoire des catalogues de ventes publiques intéressant l'art ou la curiosité... 1826-1860, La Haye, 1953.

MARTí 2018 - MARTí, Tibor: Az 1625. évi soproni országgyúlés a Habsburg-dinasztia spanyol ágának szemével: Ossona gróf bécsi spanyol követ jelentései [Der Ödenburger Reichstag von 1625 aus der Perspektive der spanischen Linie der Habsburgerdynastie: Die Berichte des Grafen Ossona, spanischer Gesandter in Wien], in $A z$ 1625. évi soproni koronázó országgyúlés [Der ungarische Krönungsreichstag in Ödenburg 1625 / The Hungarian Diet and Coronation at Sopron in 1625], hrsg. von Dominkovits, Péter - Katona, Csaba - PÁlfFy, Géza, Magyar Nemzeti Levéltár Győr-Moson-Sopron Megye Soproni Levéltára - MTA Bölcsészettudományi Kutatóközpont Történettudományi Intézet, Sopron-Budapest, 2018. (Annales Archivi Soproniensis 2.) (In Vorbereitung)

Matsche 1981 - Matsche, Franz: Die Kunst im Dienst der Staatsidee Kaiser Karls VI., Berlin-New York, 1981. 
Mátyás király öröksége 2008 - Mátyás király öröksége. Késỏ reneszánsz müvészet Magyarországon (16-17. század) [Das Erbe des Königs Matthias. Die Kunst der Spätrenaissance in Ungarn (16.-17. Jahrhundert)], Ausstellungskatalog, hrsg. von MiKó, Árpád - Veró, Mária, Budapest, 2008. (A Magyar Nemzeti Galéria kiadványai 2008/3.)

MeCENSEFFy 1955 - MeCensefFy, Grete: Habsburger im 17. Jahrhundert. Die Beziehungen der Höfe von Wien und Madrid während des Dreißigjährigen Krieges, Archiv für Österreichische Geschichte 121. 1955. 1-91.

MolnÁr 2014 - MolnÁr Antal: Carlo Caraffa bécsi nuncius az 1622. évi soproni országgyúlésen. A szentszéki diplomácia és Magyarország a harmincéves háború elsô idôszakában [Nuncio of Vienna, Carlo Caraffa, at the National Assembly of Sopron in 1622. The Diplomacy of the Holy See and Hungary during the First Period of the Thirty Year' War], in Egy új együttmúködés kezdete. Az 1622. évi soproni koronázó országgyúlés [Anfang einer neuen Kooperation. Der ungarische Krönungsreichstag in Ödenburg 1622], hrsg. von Dominkovits, Péter Katona, Csaba, Sopron-Budapest, 2014. (Annales Archivi Soproniensis 1). 125-231.

Molnár 2018 - Molnár, Antal: Egy pápai diplomata történetírói múhelyében. Carlo Caraffa bécsi nuncius az 1625. évi soproni országgyúlésen [Ein päpstlicher Diplomat als Geschichtsschreiber: Der Wiener Nuntius Carlo Caraffa auf dem Ödenburger Reichstag 1625], in Az 1625. évi soproni koronázó országgyûlés [Der ungarische Krönungsreichstag in Ödenburg 1625 / The Hungarian Diet and Coronation at Sopron in 1625], hrsg. von Dominkovits, Péter - Katona, Csaba - PÁlfFy, Géza, Magyar Nemzeti Levéltár Gyốr-Moson-Sopron Megye Soproni Levéltára - MTA Bölcsészettudományi Kutatóközpont Történettudományi Intézet, SopronBudapest, 2018. (Annales Archivi Soproniensis 2.) (In Vorbereitung)

MONOSTORI 2018 - MONOSTORI Tibor: Spanyol-németalföldi beszámoló az 1625. évi soproni királykoronázásról [A Report in Detail Stored in Brussels on the Coronation of the King of Hungary (Sopron, 1625)], in $A z$ 1625. évi soproni koronázó országgyũlés [Der ungarische Krönungsreichstag in Ödenburg 1625 / The Hungarian Diet and Coronation at Sopron in 1625], hrsg. von Dominkovits, Péter - Katona, Csaba - PÁlffy, Géza, Magyar Nemzeti Levéltár Gyôr-Moson-Sopron Megye Soproni Levéltára - MTA Bölcsészettudományi Kutatóközpont Történettudományi Intézet, Sopron-Budapest, 2018. (Annales Archivi Soproniensis 2.) (In Vorbereitung)

NAGLER, Künstlerlexikon - NAGLER, Georg Kaspar: Neues allgemeines Künstler-Lexikon Bd. I-XXV, Leipzig, 1835-1852.

NAVIO 1962 - NAVIO, Jose Lopez: La gran colección de pinturas del Marqués de Leganés, Analecta Calasanctiana 4. 1962/8. 261-330.

PÁlfFy 2004 - PÁlfFy Géza: Koronázási lakomák a 15-17. századi Magyarországon. Az önálló magyar királyi udvar asztali ceremóniarendjének kora újkori továbbélésérôl és a politikai elit hatalmi reprezentációjáról [Krönungsmähler im Ungarn des 15.-17. Jahrhunderts. Über das Weiterleben der zeremoniellen Tischordnung des selbstständigen Königreichs Ungarn in der Frühen
Neuzeit und in der Machtrepräsentation der politischen Elite], Századok 138. 2004/5. 1006-1101.

PÁlfFy 2007 - PÁlfFy Géza: A Szent Korona és a koronaláda balesete 1638-ban [Die Heilige Krone und der Unfall der Krontruhe 1638], in „Nem sûlyed az emberiség” Album amicorum Szörényi László LX. születésnapjára [„Die Menschheit geht nicht unter“ ... Album amicorum für László Szörényi zum LX. Geburtstag], hrsg. von JANKOvics, József et al., Budapest, 2007. 1431-1444.

PÁlfFY 2008 - PÁlfFY, Géza: Krönungsmähler in Ungarn im Spätmittelalter und in der Frühen Neuzeit. Weiterleben des Tafelzeremoniells des selbständigen ungarischen Königshofes und Machtrepräsentation der ungarischen politischen Elite. Teil 2, Mitteilungen des Instituts für Österreichische Geschichtsforschung 116. 2008/1-2. 60-91.

PÁlfFY 2010 - PÁlfFY Géza: A Magyar Korona országainak koronázási zászlói a 16-17. században [Die Krönungsfahnen der Länder der Stephanskrone im 16. und 17. Jahrhundert], in „Ez világ, mint egy kert...” Tanulmányok Galavics Géza tiszteletére [„Diese Welt wie ein Garten..." Festschrift für Géza Galavics], hrsg. von BubRYÁK, Orsolya, Budapest, 2010. 17-52.

PÁlffy 2013 - PÁlfFy, Géza: A Szent Korona a 17. századi Sopronban [Die Heilige Krone im Ödenburg des 17. Jahrhunderts], Soproni Szemle 67. 2013/4. (Tanulmányok Mollay Károly születésének 100. évfordulójára / Beiträge zum 100. Geburtstag von Károly Mollay), $400-411$.

PÁlfFy 2014a - PÁlfFy Géza: A Szent Korona Sopronban. Nemzeti kincsünk soproni emlékhelyei [Die Heilige Krone in Ödenburg. Ödenburger Gedenkstätten unseres Nationalschatzes], Sopron-Budapest, 2014.

PÁlfFY 2014b - PÁlfFY Géza: Hatalmi és mûvészeti reprezentáció: magyar uralkodókoronázások a kora újkori Pozsonyban [Mocenská a umelecká reprezentácia: Korunovácie uhorských panovníkov v Bratislave v období ranného novoveku], in PÁlfFY, Géza - Soltész, Ferenc Gábor - Tо́тн, Csaba: Coronatus Posonii... Bratislavské korunovačné medaily a žetóny (1563-1830) / A pozsonyi magyar uralkodókoronázások érmei (1563-1830) [Medaillen und Jetons der ungarischen Herrscherkrönungen in Pressburg (1563-1830)], Ausstellungskatalog, Bratislava-Budapest, 2014. 21-31.

PÁlfFY 2015 - PÁlfFY Géza: A szakítások és kiegyezések évszázada: a Magyar Királyság 17. századi története új megvilágításban [The century of ruptures and compromises: The history of the Kingdom of Hungary in the seventeenth century from a new perspective], Történelmi Szemle 57. 2015/1. 51-65.

PÁlfFy 2016 - PÁlfFy, Géza: Régi hagyományok, új kihívások. Uralkodókoronázások az újkori Magyarországon (a 16. század elejétôl az 1916 végi utolsó magyar koronázásig) [Alte Traditionen und neue Herausforderungen. Herrscherkrönungen im neuzeitlichen Ungarn (vom Beginn des 16. Jahrhunderts bis zur letzten ungarischen Krönung Ende 1916)], in Coronatio Hungarica in Nummis. A magyar uralkodók koronázási érmei és zsetonjai (1508-1916) [Krönungsmedaillen und Jetons der ungarischen Herrscher (1508-1916)], hrsg. von BERTÓK, Krisztina, Budapest, 2016.

PÁlfFy 2018 - PÁlffy Géza: Megerôsített lojalitás. A bécsi udvar és a magyar rendek az 1625. évi soproni ko- 
ronázódiétán [Verstärkte Loyalität: Der Wiener Hof und die ungarischen Stände auf dem Ödenburger Krönungsreichstag 1625], in Az 1625. évi soproni koronázó országgyülés [Der ungarische Krönungsreichstag in Ödenburg 1625 / The Hungarian Diet and Coronation at Sopron in 1625], hrsg. von DominKovits, Péter - KATONA, Csaba - PÁlffy, Géza, Magyar Nemzeti Levéltár Gyôr-Moson-Sopron Megye Soproni Levéltára - MTA Bölcsészettudományi Kutatóközpont Történettudományi Intézet, Sopron-Budapest, 2018. (Annales Archivi Soproniensis 2.) (In Vorbereitung)

PÁlffy-Soltész-Tóth 2014 - PÁlfFy, Géza - Soltész, Ferenc Gábor - Tóth, Csaba: Coronatus Posonii... Bratislavské korunovačné medaily a žetóny (1563-1830) / A pozsonyi magyar uralkodókoronázások érmei (1563-1830) [Medaillen und Jetons der ungarischen Herrscherkrönungen in Pressburg (1563-1830)], Ausstellungskatalog, Bratislava-Budapest, 2014.

Peltzer 1912 - Peltzer, Rudolf Arthur: Der Hofmaler Hans von Aachen, seine Schule und seine Zeit, Jahrbuch der Kunsthistorischen Sammlungen des Allerhöchsten Kaiserhauses 20. 1912. 59-182.

Polleross 1986 - Polleross, Friedrich B.: Zur Repräsentation der Habsburger in der bildenden Kunst, in Welt des Barock, Ausstellungskatalog, Chorherrenstift St. Florian, hrsg. von FeUCHTMÜlleR, Rudolf - KovÁCS, Elisabeth, Linz, 1986. Bd. I. 87-104.

Polleross 2000 - Polleross, Friedrich: Kaiser, König, Landesfürst: Habsburgische „Dreifaltigkeit" im Porträt, in Rudolstädter Forschungen zur Residenzkultur 2, München, 2000. 189-218.

Polleross 2006 - Polleross, Friedrich: Romanitas in der habsburgischen Repräsentation von Karl V. bis Maximilian II., in Kaiserhof-Papsthof (16.-18. Jahrhundert), hrsg. von BösEL, Richard, Wien, 2006. 207-223.

Polleross 2010 - Polleross, Friedrich: Austriacus Hungariae Rex. Zur Darstellung der Habsburger als ungarische Könige in der frühneuzeitlichen Graphik, in „Ez világ, mint egy kert...” Tanulmányok Galavics Géza tiszteletére [„Diese Welt wie ein Garten..."Festschrift für Géza Galavics], hrsg. von BuBRYÁk, Orsolya, Budapest, 2010. 63-78.

Polleross 2013 - Polleross, Friedrich: Gesandte im Bild. Repräsentationsformen der Diplomatie, in Politische Kommunikation zwischen Imperien. Der diplomatische Aktionsraum Südost- und Osteuropa, hrsg. von BARTHSCAlmani, Gunda - RudolPH, Harriet - StePPAN, Christian, Innsbruck, 2013. 41-68. (Innsbrucker Historische Studien 29.)

Prag um 16001988 - Prag um 1600. Kunst und Kultur am Hofe Rudolfs II., Villa Hügel, Essen - Kunsthistorisches Museum, Wien, Freren, 1988.

Preciado 2010 - Preciado, José Juan Pérez: El Marqués de Leganés y las artes I-II., Tesis doctoral (2008), Madrid, 2010. - http://eprints.ucm.es/10555/1/T31085.pdf

RÓzsA 1973 - RózSA, György: Magyar történetábrázolás a 17. században [Ungarische Geschichtsdarstellung im 17. Jahrhundert], Budapest, 1973

Rudolf II. and Prague 1997 - Rudolf II. and Prague, the court and the city, Exh. cat., Prag, Wallenstein Palais, PragueLondon-Milan, 1997.

SCHWARZENBERG 1960 - SchWARzENBERG, Karl Fürst: Die Sankt Wenzels-Krone und die böhmischen Insignien, Wien-München, 1960
SOltÉSZ-Tóth-PÁlfFy 2016 - SoltéSz, Ferenc Gábor Tóth, Csaba - PÁlfFy, Géza: Coronatio Hungarica in Nummis. A magyar uralkodók koronázási érmei és zsetonjai (1508-1916) [Krönungsmedaillen und Jetons der ungarischen Herrscher], hrsg. von BerTók, Krisztina, Budapest, 2016.

Splendeurs d'Espagne 1985 - Splendeurs d'Espagne et les villes belges 1500-1700, Exh. cat., Bruxelles, Palais des BeauxArts, Bruxelles, 1985.

Splendore dei Medici 1999 - Splendore dei Medici. Firenze e l'Europa, Catalogo mostra, a cura di ACIDINI LuCHINAT, Christina - SCALINI, Mario. Firenze, 1999.

Stichel 1999 - Stichel, Rudolf H. W.: Ein Nachtrag zum Porträtbuch des Hieronymus Beck von Leopoldsdorf: Bildnisse orientalischer Herrscher und Würdenträger in Cod. Vindob. 8615, Jahrbuch des Kunsthistorischen Museums in Wien 1. 1999. 189-209.

StroHmEYer 2013 - STROHMEYER, Arno: Kategorisierungsleistungen und Denkschemata in diplomatischer Kommunikation: Johann Rudolf Schmid zum Schwarzenhorn als kaiserlicher Resident an der Hohen Pforte (16291643), in Politische Kommunikation zwischen Imperien. Der diplomatische Aktionsraum Südost- und Osteuropa, hrsg. von BARTH-SCALMAni, Gunda - RudolPH, Harriet - Steppan, Christian, Innsbruck, 2013. 21-29. (Innsbrucker Historische Studien 29.)

Sustermans. Sessant'anni alla corte dei Medici 1983 - Sustermans. Sessant'anni alla corte dei Medici, Catalogo mostra, Palazzo Pitti, a cura di Chiarini, Marco - Pizzorusso, Claudio, Firenze, 1983.

TESZELSZKY 2009 - TesZELSZKY, Kees: Az ismeretlen korona. Jelentések, szimbólumok és nemzeti identitás [Die unbekannte Krone. Bedeutungen, Symbole und nationale Identität], hrsg. von CzIBERE, Mária, Pannonhalma, 2009. (Historia Pro Futuro)

TESZELSZKY 2011 - TesZELSZKY, Kees: A magyar korona megjelenése a kora újkori képzőmúvészetben [The socalled Holy Crown of Hungary in the Early Modern Art], Múvészettörténeti Értesítô 60. 2011. 1-10.

TeszelsZky 2014 - TesZelszky, Kees: Wirklichkeitsgetreue Darstellungen der ungarischen Krone um 1608, in Wiener Archivforschungen. Festschrift für den ungarischen Archivdelegierten in Wien, István Fazekas, hrsg. von CZIRÁKI, Zsuzsanna et al., Wien, 2014. 133-141. (Publikationen der Ungarischen Geschichtsforschung in Wien 10.)

THIEME-BeCKer - THIEME, Ulrich - BeCKer, Felix: Allgemeines Lexikon der bildenden Künstler Bd. 1-37, Leipzig, 1908-1950.

То́тн 2014 - То́тн Gergely: Lutheránus országtörténet újsztoikus keretben. Révay Péter Monarchiája [A Lutheran Country History in a Neostoic Frame. The "Monarchia" of Péter Révay], in Clio inter arma. Tanulmányok a 16-18. századi magyarországi történetírásról [Clio inter arma. Beiträge zur Geschichtsschreibung in Ungarn im 16.-18. Jahrhundert], hrsg. von TótH, Gergely, Budapest, 2014. 117-147. (Magyar Történelmi Emlékek, Értekezések)

То́тн 2016 - То́тн Gergely: Szent István, Szent Korona, államalapítás a protestáns történetírásban (16-18. század) [Saint Stephen, the Holy Crown, and the founding of the Hungarian State in Protestant historiography in the 16th to 18th centuries], Budapest, 2016.

Történelem-kép 2000 - Történelem-kép. Szemelvények múlt és müvészet kapcsolatából Magyarországon [Geschichte- 
Geschichtsbild. Die Beziehung von Vergangenheit und Kunst in Ungarn], Ausstellungskatalog, hrsg. von MiKÓ, Árpád - SinKó, Katalin. Magyar Nemzeti Galéria, Budapest, 2000.
Varjú-Höllrigl 1932 - Varjú, Elemér - Höllrigl, József: Ernst Lajos magyar történeti gyüjteménye [Ungarische historische Sammlung von Lajos Ernst], Budapest, 1932.

\section{ANMERKUNGEN}

${ }^{1}$ Die vorliegende Studie ist eine ergänzte und in den Anmerkungen aktualisierte Version der ersten Veröffentlichung des Gemäldes: BuZÁsI 1991, 149-158. Außer der Bestimmung des Malers des damals noch in ausländischem Privatbesitz befindlichen Bildes und der Darlegung seiner sammlungsgeschichtlichen Vergangenheit veröffentlichte der 1991 erschienene Aufsatz durch die hier behandelten Werke erstmalig einen Überblick über das Auftauchen der protokollarischen ungarischen Tracht und deren Rolle in der Repräsentation der habsburgischen Könige als Herrscher. Ferner wies er durch eine vergleichende Analyse eine der frühesten authentischen Darstellungen der Heiligen Krone in dem auf dem Porträt verewigten Hoheitszeichen nach. Auf die dort publizierten Feststellungen nehme ich im Weiteren keinen gesonderten Bezug.

2 „E cosi fu superbamente addobbata con tapezzarie ricchissime, et il pavimento di essa ricoperto tutto di panni rossi, verdi e bianchi, per imitari li colori dell'armi et impresa del Regno d'Ungheria." - CARAFFA 1628 (1860), 281; berichtet über die Krönung, erwähnt aber die Dekoration nicht: KHEVENHILler 1724. col. 703. Ebenda zwischen col. 705 und 706 ist die Darstellung des Schauplatzes und der einzelnen Szenen der Krönung in Ödenburg in Form eines Kupferstiches auf einem auffaltbaren Blatt zu sehen. Zu den einschlägigen Details des Wirkens des päpstlichen Nuntius Carlo Caraffa in Wien bzw. zu seinen Berichten als Gesandter über die Ereignisse der ungarischen Reichstage siehe mit Quellenpublikationen versehen - MoLNÁR 2014 sowie MOLNÁR 2018. Einen Überblick über die Aufmerksamkeit der Diplomatie, die den Reichstag 1625 begleitete, und die Berichte des Gesandten über die Krönung liefert: HiLleR 1993, vor allem: 259.

${ }^{3}$ Unter Bezugnahme auf eine unveröffentlichte Quelle publiziert bei BENDA-FÜGEDI 1979, 161. Über den bei den Krönungen im 16. Jh. verwendeten dunkelroten Teppich in Zusammenhang mit der Krönung von Maximilian II. (15641576) in Pressburg siehe neuerlich PÁLFFY 2014b, 24.

${ }^{4}$ Beispiele für das Gewand, das bei der Krönung des ungarischen Königs getragen und in einzelnen Quellen ungarisch genannt wurde, zählt Géza Pálffy vom 16. Jh. an auf, samt Quellendetails in Bezug auf den von Maximilian (1563), Rudolf II. (1572) und Matthias II. (1608) getragenen dunkelroten Mantel bzw. die Mente mit Zobelpelz von Matthias II.: PÁlfFY 2004, 1050/Anm. 223; bzw. überarbeitete deutsche Version: PÁlfFy 2008, 76/Anm. 174.

5 „In ultima veniva il nuovo Re, vestito all'Unghera sotto di tela d'argento e sopra di velluto rosso con fodera di bellisimi zibellini, et haveva un berrettino all'Unghera di felpa nera con un gran mazzo d'aironi e con un diamante stimato quaranta mila tallari." - CARAFFA 1628 (1860), 283; zuletzt MOLNÁR 2018.

${ }^{6}$ „Después de todos estos venía el rey, vestido a la húngara, con una joya en el bonete, y entre otros diamantes que tiene hay uno de 50 mil escudos." Siehe MonOsTORI 2018.
${ }^{7}$ Ungarische Nationalgalerie Sammlung Alte Kunst, Inv.-Nr.: $92.20 \mathrm{M}$, Öl auf Leinwand, $201 \times 126 \mathrm{~cm}$. Die Sammlung erwarb das Bild mit einem Dreiertausch aus dem Besitz des damals nach Wien delegierten UN-Diplomaten und Sammlers William L. Eagleton, der es Jahrzehnte zuvor am Schauplatz seines früheren Wirkens, in Madrid, gekauft hatte.

${ }^{8}$ Die erste Veröffentlichung siehe hier, an der Spitze der Anmerkungen. Justus Sustermans (1597, Antwerpen 1681, Florenz) stand von 1620 an im Dienste der Medicis in Florenz, als Hofmaler von Cosimo II. Medici. 1623-1624 arbeitete er in Wien. Wichtigste Literatur dazu: BAUTIER 1912; Sustermans. Sessant'anni alla corte dei Medici 1983; THIEME-BECKer Bd. 32. (1938) 322-325; sowie die sich auf seine Werke beziehenden, unten zitieren Literaturen.

${ }_{9}^{9}$ Frans Baudouin, Direktor des Rubenshuis in Antwerpen, bekräftigte mündlich die Zuschreibung, als er sich am 23. April 1996 das Bild in der Dauerausstellung der Alten Sammlung der Ungarischen Nationalgalerie anschaute.

${ }^{10}$ BuZÁSI 1991; weitere Literatur und wichtigere Erwähnungen des Bildes: Galavics 1993, 23; Galavics 2001, 9-18, hier 13; F. DÓzsA 2001, 24; A koronázási jelvények okmányai 2002, 17 (Dokumente der Krönungsinsignien); PÁlFFY 2007, 1435; Mátyás király öröksége 2008, 114 (Kat.Nr. II-44; BuZÁsI, Enikô): Justus Sustermans (1597-1681) und seine Werkstatt: Bildnis des ungarischen Königs Ferdinand III., 1626; BuZÁsi 2009, 13-15; POlleross 2010, 65; PÁlfFy 2013, 403; PÁlfFy 2014a, 51-52.

${ }^{11}$ Umschrift des Porträtstiches von Ferdinand III.: „SERENISS(imus). AC. POTENTISS(imus). PRINCEPS AC. DOMINUS. D(omi)N(us). FERDINANDUS. III. REX. HUNGARIAE. ET. BOHEMIAE. ARCHIDUX. AUSTRIAE. DUX. BURGUND(iae). STYR(iae). CARINT(hiae) CARNIOL(ae). ET. WIRTEMB(ergiae) COMES HABSP(urgi). TYROL(is). GORIT(iae). LANDGRAV (ius). ALSAT(iae)." Darunter ein sechszeiliges lateinisches Distichon sowie die Signatur: Wolf. Kilian Scalp. et excud. MNM TKCs Inv.-Nr. 10.454 bzw. 8902.

${ }^{12}$ Erschienen: Deß aller Durchleüchtigsten Haus Oesterreichs Herzogen, Ertzhertzogen, König und Kayser eigentliche Contrafacturen. In Verlag Wolffgang Kiliani. Augsburg 1629.

${ }^{13}$ Der in Bezug auf die Einzelheiten unmittelbarste Abkömmling des Kilian-Stiches mit dem gleichen Text ohne den Namen des Stechers: ÖNB Bildarchiv PORT 00046570; Komposition schwächerer Qualität von einem unbekannten Stecher, mit übereinstimmendem Text in der Umschrift und in der Komposition mit seitenverkehrter Darstellung Ferdinands III.: MNM TKCs Inv.-Nr.: 1330, Inv.-Nr.: 1997. Letzteres siehe auch: ÖNB Bildarchiv PORT 00046569; eine damit völlig identische Version veröffentlichte Matthäus Merian in: Theatrum Europaeum ... von ... 1629 bis auff das Jahr 1633... Bd. II. Frankfurt am Main, 1646. 292. Siehe: ÖNB Bildarchiv PORT 00046567. Eine in der Aufschrift übereinstimmende Version: MNM TKCs Inv.-Nr.: 1331 
Siehe DiEPENBROICK-GRÜTER 1967, 6032; Reiterporträt ebenfalls in ungarischer Tracht, im Hintergrund eine Schlachtszene, von einem unbekannten Stecher: MNM TKCs Inv.Nr.: 224/1914.

${ }^{14}$ Alle Kupferstiche: Michel van Lochom: MNM TKCs Inv.-Nr.: 1998, ÖNB Bildarchiv PORT 00046566; Baltazar Moncornet: MNM TKCs Inv.-Nr.: 1996, ÖNB Bildarchiv PORT 00066945.

${ }^{15}$ Kupferstich, ÖNB Bildarchiv PORT 00046568. Links über Regensburgs Rückeroberung das Datum 1634, unter dem oval umrahmten Porträt ein sechszeiliges Hexameter, am Ende die bisher noch nicht identifizierte Signatur G.S.R.B.

${ }^{16} \mathrm{Zu}$ dessen Bedeutung im internationalen diplomatischen Protokoll siehe auch MARTí 2018.

${ }_{17}$ Über die Ikonographie der Habsburgherrscher umfassend: MATSCHE 1981. Einen ausführlichen Überblick über die Frage liefern: Kovács 1986, Bd. I. 53-86; sowie PolLEROSS 1986; Polleross 2006. Über die Ikonographie der als Ungarns König dargestellten Habsburgherrscher jüngstens: Polleross 2010.

${ }^{18}$ Vgl. PÁlfFY 2015, 57

${ }^{19}$ In diesem Zeichen erschien Erzherzog Matthias (der zukünftige Matthias II.) auf seiner Krönung am 19. November 1608 in Pressburg, noch dazu auch Erzherzog Maximilian, der zu seiner Begleitung gehörte und neben dem Palatin Illésházy ebenfalls eine Rolle im Zeremoniell spielte - beide mit dem äußeren Erscheinungsbild, wie ein unbekannter spanischer Teilnehmer es in seinem Krönungsbericht festhielt: „Viejo, con otra espada desnuda, q es Marischalco d'Vngria, y luego el Rey, bestido a la Vngara, conuna Aljuba, de brocado, colorado, y una ropa de paño morado, a forrada de zevellinas, con bonete pequeño de lena, de los ordinarios. Una medalla, con un diamante gr[an]de media dozena de Martinetes. Y un sable, y los dos obispos, cadauno a su lado, y detras del el Archiduque Maximiliano, bestido tambien a la Vngara, con Vna ropa de Grana aforrada de cebellinas, y un bonete de selpa, y de tras del monseñor el nuncio, y llegado el Rey cerca del altar mayor, todas las enserias fueron puestas sobre el altar." Las cerimonias de la coronacion del Archiduque Mathias por Rey de Vngria, Miercoles XIX de Nouiembre de 1608. Biblioteca Nacional de España, Madrid; Mss. 3207, p. 101-102. Für die Information über die Quelle und die Möglichkeit ihrer Verwendung bin ich Tibor Marti zu Dank verpflichtet.

${ }^{20}$ Beispiele siehe in PÁlfFY-SOltÉsz-Tóth 2014, Nr. 61-65; SOlTÉSz-TóTH-PÁlfFy 2016, Nr. 81-86, Nr. 25-38. Hinsichtlich der Genauigkeit der Darstellung ist anzumerken, dass seitliche Pendilien auf der Krone auf keiner einzigen numismatischen Arbeit zu sehen sind.

${ }^{21}$ Lucas Kilians signierter Kupferstich ist mit 1610 datiert: ÖNB Bildarchiv, PORT 00046145. Unter dem Porträt steht ein in Rollwerk-Kartusche geschriebenes Distichon auf der mit 1610 datierten ersten Version: „Conspicuus uultu MATTHIAS Austruis [sic] hoc est, REX capit HVNGARICI quum Diadema soli." Unten steht eine sechszeilige Legende, die die Signatur des Stechers und das Datum beinhaltet: „SERENISS(im)o et POTENTISS(im)o PRINCEPI [sic] ac D(omi)NO. D(omi)N(o). MATTHIAE II REGI HVNGARIAE, DALMAT(iae). CROAT(iae). SLAVON(iae). CORONAT(o), BOHEMIAE DESIGNAT[o]. ARCHIDVCI AVSTRIAE, DVCI BVRGVNDIAE, STIRIAE, CARINTHIAE, CARNIOLAE. etc. MARCH(ioni). MORAVIAE etc.
REGI ac D(omi)NO SVO CLEMENTISS(imo) humil(iter) et subiectiss(ime) consec(rat) Lucas Kilianus Chalcog(raphus) ciu(is) Aug(ustanus) Vindel(icorum) M. DCX." Unsigniertes, undatiertes Exemplar: OSZK RMNy App. M. 43. Die ungarische Literatur gibt meistens diese Version an; siehe RózSA 1973, 30; A koronázási jelvények okmányai (Dokumente der Krönungsinsignien), 2002, 12, 13; Abb. 1.

22 Zweite Ausgabe, versehen mit dem Datum 1611: ÖNB, Bildarchiv, PORT 00046144. In der Rollwerk-Kartusche: „Hoc nunc conspicitur MATTIAS AVSTRIVS ore REX gerit HVNGARICAM, dum BOIEMAMQVE, CORONAS." Darunter eine sechszeilige Legende, ebenfalls mit der Signatur und dem Datum: „SERENISS(im)o et POTENTISS(im)O PRINCIPI ac D(omi)NO. D(omi)N(o). MATTHIAE II REGI HVNGARIAE, BOHEMIAE, DALMAT(iae). CROAT(iae). SLAVON(iae). CORONATO: ARCHIDVCI AVSTRIAE, DVCI BVRGVNDIAE, STIRIAE, CARINTH(iae), CARN(iolae). SILES(iae). etc. MARCH(ioni). MORAVIAE, SVPER(ioris). et INFER(ioris). LVSATIAE, etc. REGI ac D(omi)NO SVO CLEMENTISS(imo) humil(iter) et subiectiss(ime) consec(rat) Lucas Kilianus Chalcog(raphus) ciu(is) Aug(ustanus) Vindel(icorum) M.DCXI." In Zusammenhang mit der Krönung von Matthias II. zum ungarischen König publiziert in: Kaiser und König 2001, 135 (Kat.-Nr. 19/4).

${ }^{23}$ Heinrich Ulrich/Ullrich (nachweislich zwischen 1572-1621) arbeitete in Nürnberg von 1595 an (vgl. THIEME-BECKER Bd. 33. [1939] 561). Sein signierter Kupferstich: ÖNB, Bildarchiv, PORT 00046147. Umschrift: „SERENISS(imus). POTENTISS(imus). PRINC(eps) AC DOM(inus). D(ominus). MATTHIAS CORONATUS REX HUNGARIAE DESIGNATUS BOHEMIAE ARCHIDUX AUSTRIAE DUX BURGUNDIAE STYRIAE CARINTHIAE CARNIOLAE ET WIRTEMB(ergiae). MARCHIO MORAVIAE COMES HABSPURG(i). ET TYROLIS." Darunter ein sechszeiliges lateinisches Elogium sowie rechts die Signatur: „Hainruh Vlruch [sic] Sculp[si]t." Unsigniertes Exemplar: MNM TKCs Inv.-Nr.: 3138.

${ }^{24}$ Hammer-Purgstall 1845, 815

25 ÖNB, Bildarchiv, PORT 00046146, der Autor ist nicht identifiziert. Umschrift auf dem Stich: „MATHIAS REX BOHEMIAE ET HVNGARIAE ARCHIDVX AVSTRIAE." Um das Emblem, dargestellt auf der Brüstung: „SALVTEM EX INIMICIS NOSTRIS“ [,... et de manu omnium qui oderunt nos." Lk. 1:71.] Unter dem Bildnis: „CORONAT(us) PRAGAE DIE XXIII MAII. 1611 - questo ritratto senza lettere era del'uno, et l'impresa dell'altra banda delle monete buttate al Populo nell'incoronatione. Romae sup(er)ior lice(n)tiae MG [in Ligatur] exc. cu(m) Priuileg(ium).“

26 Ähnlich werden die bei der Krönung unter das Volk gestreuten Jetons beschrieben: HAMmER-PURGSTALL 1845, 819. Bezugnahme auf bestehende Exemplare der Jetons: BerninG 2008, 212 - hier wird die Krönungsmedaille aufgrund einer erhalten gebliebenen Arbeit bzw. Literatur beschrieben: mit einem Emblem auf der Rückseite (über das Emblem selbst: 213). Auf dem Foto wird aus der Staatlichen Münzsammlung München das Exemplar der von ihm erwähnten Krönungsmedaillen von Matthias II. publiziert (ebenda Abb. 9), welches das Herrscherporträt und auf der Rückseite das Datum der Krönung angibt: „MATTHIAS II D(ei) G(ratia) HVNG(ariae) REX CORONAT(us) IN REGEM BOHEMIAE AN(no) 1611 DIE 23 MAII." Vermutlich stach Paul Mayr, der Anfang des Jahrhunderts mit Heinrich Ulrich arbeitete, ebenfalls ein Medaillenbild in Kupfer (NAGLER Bd. VIII. 1839, 
496; THIEME-BeCKer Bd. 33. [1939] 561, hier unter dem Stichwort Ulrich). Sein auf 1611 datierbares, medaillenartig in runder Form komponiertes Profilporträt stellt Matthias II. als böhmischen und ungarischen König in einer ungarischen Pelzkragen-Mente und einem Hut mit Pelz und Federbusch dar. Publiziert von: Polleross 2000, 190 (Abb. 1).

${ }^{27}$ Hammer-Purgstall 1845, 819. Die böhmische Krönungszeremonie wird ausführlich beschrieben von SCHWARZENBERG 1960, 46-52, er erwähnt jedoch kein Beispiel dafür, dass man die Zustimmung der Vertreter des Volkes zum Anwärter der Krone als Herrscher eines anderen Landes verlangt hätte (ebenda 47).

28 BERNING 2008, 100.

${ }^{29}$ BERNING 2008, 100. Das in der Quelle beschriebene Gewand: „... in einem langen grünsammeten ungarischen rock mit weissilbern tuch gefutert und einem schwarzen ungarischen hütlein mit einem kleinen schwarzen federbüschlein." Der Ausdruck der doppelten - böhmisch-ungarischen Königswürde mit der ungarischen Tracht auf dem Bild war vermeintlich zugleich auch ein Signal an Kaiser Rudolf II., der zum Rücktritt von seinem Titel als böhmischer König genötigt wurde.

30 Sbírky Pražského hradu, Praha; Inv.-Nr. O 304. Öl auf Leinwand, $184,5 \times 116,5 \mathrm{~cm}$. Siehe Peltzer 1912, 142, Tafel XX; An der Heiden 1970, 175, 203-204 (Nr. A 32), Abb. 141; Prag um 1600 1988, 221 (Kat.-Nr. 106; FuČíkOvÁ, Eliška), Tafel 16; Rudolf II. and Prague 1997, 393 (Kat.-Nr. 20; FuČíkOvÁ, Eliška); JACOBY 2000, 241 (Nr. 88), Farbtafel 11.

${ }^{31}$ Zur heraldischen Rolle des Pfaus, verbunden mit dem Hause Habsburg, siehe KUSTER 2011-2012.

32 Prag um 1600 1988, 221 (Kat.-Nr. 106; FučíkovÁ, Eliška).

${ }^{33} \mathrm{KHM}$, Öl auf Leinwand, $201 \times 107 \mathrm{~cm}$. Peltzer 1912, 143-144, Abb. 69; HeInz 1963, 194 (Nr. 55); An der HeIDEN 1970, 204 (A.33), Abb. 142 und 143; JACOBY 2000 , 242-244 (Nr. 89); Polleross 2000, 191, Abb. 5.

${ }^{34}$ Jacoby 2000, 243; weiters Peltzer 1912, 168 (Nr. 122, 123) bzw. 179 (Urkunde 44), hier in 12 Posten angeführte 20 Bilder, darunter ein Porträt des Königs in böhmischem Ornat mit der Krone dargestellt: 150 Taler, „conterfect in Ungerischen klaidern, ganze lenge" für einen Preis von 100 Taler. Es ist anzumerken, dass das Bild in der ungarischen Tracht für die Fürstin von Braunschweig gefertigt wurde, genauso wie das gleichenorts befindliche Ganzfigurenporträt (wahrscheinlich ein Paarstück) über Kaiserin Anna (für den gleichen Preis), jedoch ohne eine Anmerkung, ob sie zu ihrem Bestimmungsort geschickt wurden, was hingegen bei den übrigen Posten der Rechnung erscheint. So können der Gegenstand der Angabe und das heute in Prag befindliche Exemplar eventuell auch identisch sein.

35 Bekanntlich beschäftigte Kaiser Rudolf bis zu seinem Tod am 20. Januar 1612 Hans von Aachen. Die Forscher schließen dennoch nicht aus, dass Matthias II. dem Maler auch schon vor diesem Datum Aufträge erteilte; siehe JACOBY 2000, 64; FuČíKOVÁ 2010, 10.

36 Peltzer 1912, 168 (Nr. 127, 128) bzw. 179 (Urkunde 44).

${ }^{37}$ Die Historische Bildergalerie des Ungarischen Nationalmuseums bewahrt drei Anfang des 17. Jahrhunderts entstandene Ölbilder der Darstellungen in ungarischer Tracht auf. Eine Brustbild-Miniatur, vermutlich von einem Prager oder Wiener Künstler, die mit einer anspruchsvollen, feinen
Lösung gefertigt wurde, mit gewissen Verschleißspuren auf der Oberfläche, wodurch die Vorzeichnung mit Feder auf dem Gesicht zum Vorschein kommt (MNM TKCs Inv.-Nr. 745, Öl, 9,1 $\times 5,2 \mathrm{~cm}$ ) - das wird im Obigen auch als Foto publiziert. Ferner ein kleines Brustbild mit größerem Ausschnitt, das mit dem Vorherigen in den Details und in den Farben gleicherweise übereinstimmt und wie eine Kopie davon aussieht (MNM TKCs Inv.-Nr.: 373, Öl, 16,6×9 cm). Seine Eigenschaft als Kopie wird dadurch belegt, dass sein Maler, der die Komposition des Vorbildes ein wenig erweiterte, statt des Ordens vom goldenen Vlies (der auf der Miniatur nur teilweise dargestellt ist und den er auf diese Weise fehlinterpretierte) einen vierzackigen, mit Edelsteinen besetzten Stern als Anhänger auf die Ordenskette am Hals des Herrschers setzte. Wenngleich dieses letztere Bild aus dem Besitz der Familie Révay stammt, können wir wegen der fehlerhaften Ordensdarstellung kaum annehmen, dass es mit Péter Révay (1608-1622) zu tun haben könnte, der zur Krönung von Matthias II. zum Kronwächter ernannt wurde und diese Würde bis zu seinem Tod bekleidete. Ein Matthias-Porträt, ebenfalls in ungarischer Tracht, gelangte aus dem Besitz von Lajos Ernst in die Sammlung des Museums (MNM TKCs Inv.-Nr.: 1578, Öl auf Leinwand, $73,8 \times 53,8 \mathrm{~cm})$ - sein Foto ist hier ebenfalls zu sehen. Auf diesem ist der Herrscher in ungarischer Tracht dargestellt, die mit dem blau-schwarzen Kleid auf der Hans von Aachen-Darstellung verwandt ist. In der Ernst-Sammlung ohne Provenienz erwähnt von: VARJú-HöllRIGL 1932, 50 (Kat.-Nr. 36)

${ }^{38}$ Vgl. КÖHBACH 1999, 177-183.

39 GONDA-Niederhauser 1977, 69; Hiller 2001, 48.

${ }^{40}$ Zum neuesten Überblick der Darstellungen in Zusammenhang mit den Gesandtenreisen, vor allem mit der diplomatischen Mission an der Hohen Pforte siehe Polleross 2013, 49. Weitere Literatur zum Thema siehe in Anm. 42.

${ }^{41}$ KHM Wien. Siehe ausführlich in Zusammenhang mit der Interpretation der ungarischen Kleidung und der Geschichte von Kreckwitz: Galavics 1986, 36. Zum Gesandten in Konstantinopel, Kreckwitz, zuletzt: BAGI 2011-2013, 125. Das betroffene Stück der Hans von Aachen-Serie mit der früheren Literatur: JACOBY 2000, 186 (Nr. 60,2, bei unpräziser Deutung des historischen Hintergrundes); Hans von Aachen (1552-1615) Hofkünstler in Europa 2010, 238 (Kat.Nr. 94; SCHÜTZ, Karl), mit dem stichhaltigen Vorschlag von Schütz in Bezug auf die Person von Kreckwitz und den Inhalt der Szene.

${ }^{42}$ Figurae calamo exaratae et coloribus distinctae videlicet variorum Turcarum imperatorum, capitaneorum aliorumque officialium imagines, deinde habitus, ludos, caerimonias etc. repraesentantes. [1586] ÖNB Wien, Handschriftensammlung Cod. 8615. Fol. 31 $1^{\mathrm{r}}$. Über das Werk und die Porträts ausführlich: STICHEL 1999, besonders 202, und Abb. 195. Nach Stichels Feststellung gehörte das Porträt mit Dreiviertelansicht früher zum Porträtbuch von Hieronymus Beck von Leopoldsdorf (KHM, Gemäldegalerie, Inv.-Nr. 9691), so wie die Brustbilder, die türkische Sultane und Amtsvorgänger darstellen. Auf einer Seite des Bandes mit der Signatur Cod. 8615 ist auch eine an ihn gerichtete Widmung zu lesen. Aus Becks Porträtsammlung, die ursprünglich aus gesonderten Blättern bestand, wurden nach seinem Tod und bevor sie in die kaiserliche Bibliothek gelangte, 18 Darstellungen abgetrennt. Diese kamen später als ein geson- 
derter Band (Cod. 8615) in den Bestand der Hofbibliothek. Hieronymus Beck nahm ab 1584 ebenfalls an der Reise des kaiserlichen Gesandten Heinrich von Liechtenstein zu Nikolsburg nach Konstantinopel teil. Der Gesandte starb während seiner Reise und wurde in Gallipoli beigesetzt. $\mathrm{Zu}$ Heinrich von Liechtensteins Reise und den Namen der Teilnehmer siehe den ausführlichen Bericht seines Begleiters, Melchior Besold: BüCHEL 1925, besonders: 48-75, Löwenklau wird erwähnt: 72-75.

${ }^{43}$ Die Identifizierung der im Kodex dargestellten Person in ungarischer Tracht führte - mangels vergleichenden Materials - weder mit Heinrich von Liechtenstein noch mit dem auch auf einem selbstständigen Stich dargestellten kaiserlichen Gesandten David von Ungnad zum Ergebnis. All das wird außer Stichels Studie (STICHEL 1999) mit reichlicher Information und Literatur bezüglich der erwähnten Personen ausführlich behandelt von: Ács 2010.

${ }^{44}$ MNM TKCs Inv.-Nr. 9733, Kupferstich. Erste Veröffentlichung des im Besitz der Fürsten Liechtenstein befindlichen Gemäldes: Galavics 1993, 29 sowie Abb. 5; Baroque Art in Central Europe 1993, 231 (Kat.-Nr. 59; GALAVICS, Géza): Elias Widemann nach Jeronimus Joachims: Johann Rudolf Schmid, Gesandter des Wiener Hofes an der Hohen Pforte, 1651; Kaiser und König 2001, 133 (Kat.-Nr. 18/3). Erstmals mit der Veröffentlichung der Stichversion: Galavics 1986, 77, Abb. 51. Über Johann Rudolf Schmid jüngstens: Strohmeyer 2013; sowie Polleross 2013, besonders 42-55. Fragen der diplomatischen Beziehungen Europas und des Wiener Hofes mit der Hohen Pforte im 17. Jahrhundert werden auch in weiteren Publikationen Arno Strohmeyers ausführlich behandelt. Ihre Liste siehe: Aetas 31. 2016/3. 147-153. An der Herausgabe der Gesandtenberichte aus Konstantinopel von Schmid arbeiten seit Jahren István Fazekas, István Hiller und Dóra Kerekes.

${ }^{45}$ KHM Wien, Öl auf Leinwand, $260 \times 113 \mathrm{~cm}$ (Inv.-Nr. 697) beziehungsweise $260 \times 112 \mathrm{~cm}$ (Inv.-Nr. 699). Zu den Porträts von Jan van den Hoecke siehe Die Gemäldegalerie des Kunsthistorischen Museums in Wien 1991, 68. Der Stich des Triumphbogens herausgegeben: GEvAERTs, Gaspar: Pompa Introitus honori Serenissimi Principis Ferdinandi Austriaci, Antwerpen, 1642. Zum historischen Hintergrund des Themas siehe den Vortrag von Rubén González Cuerva (The King of Hungary and the Cardinal of Toledo: Warrior Cousins and the Creation of a Common Dynastic Image around the two King Ferdinands [1631-1635]) auf der spanischungarischen Konferenz am 5. und 6. April 2016 in Budapest mit dem Titel The Representations of Power and Sovereignty in the Kingdom of Hungary and the Spanish Monarchy in the $16^{\text {th }}$ $18^{\text {th }}$ Centuries.

${ }^{46}$ Beispiele für das Militärgewand mit kurzem Dolman ergänzt mit einem Brustharnisch findet man auf mehreren Grabsteinen mit Helden-Ikonographie aus der ersten Hälfte des 17. Jahrhunderts, wie z.B. auf den Grabsteinen von Johann Tapolcsányi, 1598 (Kistapolcsány / Topolčianky, SK), Stephan Illésházy, 1608 (Bazin / Pezinok, SK) oder Georg Thurzó, 1616 (Ârva vára / Oravský hrad, SK). Fotos siehe: Galavics 1986, Abb. 31, 34 und 38

${ }^{47} \mathrm{Vgl}$. MATSCHE 1981, 88-89, 128, 133-134, 137-138, 142, 157, 168-172, 270-271; KovÁcs 1986, 64, 66-67, 75; BROUCEK 1986, 107.

${ }^{48} \mathrm{Zu}$ Ferdinand III. grundsätzlich siehe HenGerer 2012. Über die innenpolitische Abstimmung vor der Krönung zum König Ungarns, über die Krönung selbst sowie über die politische Vorgeschichte der Ehe des Erzherzogs siehe als kurze Information, großteils aufgrund Khevenhillers Arbeit: 57-64. Zur internationalen Vorgeschichte der geplanten Heirat und zu den Details der Vorbereitungen, ferner zur Annahme der Königswahl durch den Ödenburger Reichstag siehe Hiller 1989; Martí 2018; sowie PÁlfFY 2018.

${ }^{49}$ Neben der in der vorigen Anmerkung zitierten Literatur - vor allem bei HiLler 1989, 60-61, 63, 67 - siehe CARAFFA 1628 (1860), 270, 275-276; KHEVENHILler 1724, Bd. X. col. 702; ein zusammenfassender Überblick bei FRAKNÓI 18681872, hier Bd. II. 154; FraKNói 1921, 234; bzw. mit neuen Angaben bei MARTí 2018.

${ }_{50}$ Zur Einberufung und Abwicklung des Reichstages sowie zu der nach sorgfältiger politischer Vorbereitung auf die Tagesordnung gesetzten Königswahl siehe ausführlich: Hiller 1989, 61; ferner den neulich erschienenen Studienband, der das neue Kapitel der politischen Beziehungen zwischen den ungarischen Ständen und dem Wiener Hof, vor allem im Jahr 1622, ausführlich behandelt: Egy új együttmüködés kezdete 2014; sowie siehe PÁlfFY 2018.

${ }^{51}$ FrAKNói 1921, 233; Hiller 1989, 63.

52 Fraknói 1868-1872, Bd. II. 169; Fraknói 1921, 232239; Hiller 1989, 62-64

${ }^{53}$ FRAKNÓI 1868-1872, Bd. II. 167-168.

${ }^{54} \mathrm{Als}$ früheste Medaillen-Darstellung der Eidesleistung bei der Krönung wird erwähnt bei PÁlfFY 2016, 17; sowie siehe ebenda 101, 107, unter Nr. 68.

55 Coronatio Hungarica in Nummis 2016, 108 (Nr. 70, 71).

${ }^{56}$ BERNing 2008, Abb. 9.

57 Siehe die zur Krönung von Matthias II. in Pressburg geprägten Medaillen: Coronatio Hungarica in Nummis 2016, Nr. 81-85, 25-32, 34.

58 Unter anderem: Történelem-kép 2000, 426-428 (Kat.Nr. VII-1; MıKÓ, Árpád): A Szent Korona a tartományok címereivel, 1621 (Die Heilige Krone mit den Wappen der Kronländer); BERTÉNYI 2001, insbesondere 23; A koronázási jelvények okmányai 2003, 13-16; Mátyás király öröksége 2008, 115-119 (Kat.-Nr. II-45a-d; BuzÁsI, Enikô): „Országtáblák”, a Szent Korona a tartományok címereivel („Ländertafeln“, die Heilige Krone, umrahmt mit den Wappen der Kronländer); TESZELSZKY 2009, vor allem 277-280; PÁlfFy 2010, 33-34; TesZelszkY 2011; TesZelsZky 2014; TótH 2014, 122-124; BuZÁSI-PÁLFFy 2014, besonders 246249; BuZÁSI-PÁlfFY 2015, passim, besonders 126-133. Die Kenntnisse über die Krone Anfang des 17. Jh. und die Interpretation ihrer Darstellungen hat in jüngster Zeit Gergely Tóth untersucht: TóTH 2016.

59 BUZÁsI 1991, 152.

${ }^{60}$ Kilians Stich ist erschienen bei: RÉVAY, Péter: De Sacrae Coronae Regni Hvngariae Ortv, Virtvte, Victoria, Fortvna, Annos Vltra DC. Clarissimae Brevis Commentarivs PETRI DE REWA Comitis Comitatvs de Tvrocz. Avgustae Vindelicorvm [...] M.DC.XIII. RMK. III. 1118. Titelblatt. Der Wortlaut der Abhandlung in ungarischer Übersetzung von Péter Kulcsár in A korona kilenc évszázada 1979, 195-232. Eine weitere Bearbeitung und Bewertung des Werkes: BónIs 1981, 5261; sowie Тóтн 2016, vor allem 48-52. Zum zeitgleichen historischen Interesse für die Krone sowie für ungarische Werke, die sich mit der Krone befassen: BónIs 1981, 44-46, 49-50; ferner Holl 1980, 160-162. In Zusammenhang mit einer weiteren und grundlegenden Bearbeitung von Révays 
Buch beschäftigt sich mit dem Stich: TeszelszkY 2009, 215327; ferner Teszelszky 2011, 5-6. Die im 17. Jh. neu gestochenen Versionen der Kronendarstellungen im Révay-Buch werden behandelt von: BuZÁsi 2011.

${ }^{61}$ Die besondere Aufmerksamkeit für den Herrscher Matthias II. in den Arbeiten von Péter Révay hebt auch Gergely Tóth in seiner wissenschaftshistorischen Zusammenfassung der Schriften des Autors im 17. Jahrhundert hervor. TótH 2014, 125

62 PÁlfFy 2007.

${ }^{63}$ Aus den für den Maler erreichbaren beziehungsweise verfügbaren bildlichen Quellen kann man außer dem bereits erwähnten, 1613 erschienenen Stich Wolfgang Kilians hierzu zählen auch das bekrönte Porträt von Matthias II. beziehungsweise die Darstellung seines Wappens mit der Krone in der Abhandlung von JEszEnszKY, Johannes: Regis Ungariae, Matthiae II. coronatio. Wien, 1609 (siehe TesZELSZKY 2009, Abb. 13-15), sowie den auch im vorliegenden Aufsatz angeführten Kupferstich von Lucas Kilian über Matthias II. im Krönungsornat (1610, 1611). Noch weniger Informationen als die Stiche enthalten für die farbgetreuen, authentischen und präzisen Kronendarstellungen jene zur Krönung von Matthias II. geprägten, bereits erwähnten Medaillen, die so ebenfalls keine bildliche Vorlage zur Krone des Porträts von Ferdinand III. bedeutet haben könnten. Jenes Bild der Heiligen Krone, das laut Archivquellen aufgrund eines authentischen Vorbildes gefertigt wurde (siehe BUZÁSI-PÁLFFY 2015, 35-44) und das in Clemens Jägers dynastiegeschichtlichem Werk, im Ehrenspiegel des Hauses Österreich, sowie dessen drei Kopien vom Ende des 16. Jh., um 1600, enthalten sind, kann trotz des hohen Grades der Genauigkeit in den Farben und den zeichnerischen Details nicht als Vorbild in Betracht gezogen werden, weil weder das damals in München aufbewahrte Originalexemplar von Jägers Werk noch dessen in Wien beziehungsweise in Innsbruck sowie in Mergentheim, dem Sitz des Deutschen Ritterordens, zu vermutenden drei Kopien für den Maler zugänglich waren. Zur Geschichte der Ehrenspiegel-Exemplare siehe: BuZÁsIPÁlfFy 2015, 63-107. Obwohl in Bezug auf die formalen Merkmale der Details und der Goldschmiede-Elemente auch jene Kronendarstellung sehr präzise ist, die 1618 auf der von Nikolaus Esterházy getragenen KrönungsLandesfahne über dem ungarischen Wappen zu sehen war, können wir sie nicht als Vorbild für die Darstellung des Porträts von Ferdinand III. betrachten. Die Schuppenmusterverzierung der Zierate auf der Fahne ist goldfarbig, d. h. nicht identisch mit der durchschimmernden grünen Farbe der à jour-Verzierungen, was Sustermans' Bild richtig zeigt. Außerdem sieht man auf den Bügeln der corona latina überall eine Reihe weißer Perlen gegenüber dem abwechselnden weißen und roten Perlenschmuck wie auf der Heiligen Krone und dem Ferdinand-Bildnis. Vgl. zu dieser Frage: PÁlFFY 2010, 6, schwarz-weißes Bild.

${ }^{64}$ Siehe die in der nächsten Anm. angeführte Literatur.

${ }^{65}$ Die grundlegende und ausführliche Bearbeitung der Frage siehe: PÁlfFY 2004, zum Ordo der Krönungsbankette und zur Platzierung der Krone während der Bankette: 1051. Das Tafelzeremoniell des Krönungsbanketts von Ferdinand III. mit Bekanntgabe der Teilnehmer und ihr Tafeldienst: 1077-1078. Zum Schauplatz der Krönungsbankette in Ödenburg sowie über die Zurschaustellung der Krone dort:
PÁlfFY 2013, 408. Im Übrigen siehe noch: PÁlfFY 2007, 1434-1435.

${ }^{66}$ Die Krone, über deren Ausführung der Nuntius Caraffa sich kritisch äußerte („é di assai rozza fattura“), wurde in einer mit rotem Samt bedeckten und mit Goldbeschlägen versehenen Kiste am 30. November vom gewöhnlichen Aufbewahrungsort, der Burg von Pressburg, nach Ödenburg gebracht. („Tutti questi Reali ornamenti furono portati in Edemburgh la Dominica, ultimo giorno di Novembre..."). Siehe CARAFFA 1628 (1860), 280; sowie KHEVENHILler 1724, Bd. X. col. 703. Als weitere Literatur: HeNGERER 2012 - hier wird in Anm. 389/27 das gleiche Datum unter Bezugnahme auf das Tagebuch von István Aszalay mitgeteilt. Auch die jüngste Bearbeitung des „Aufenthaltes“ der Krone in Ödenburg gibt diesen Tag an: PÁlfFY 2013, 403; PÁlfFY 2014a, 45-46, 82-83 (Aufenthaltsdauer der Krone in Ödenburg: zwischen 30. November und 14. Dezember erwähnt), 52 (Aufbewahrungsort im Quartier der Herrscherfamilie).

${ }^{67}$ Die farbgetreue, auch in den Details übereinstimmende Kopie des Porträts mit Brustbild-Ausschnitt dürfte in der ersten Hälfte des 18. Jahrhunderts entstanden sein. MNM TKCS Inv.-Nr. 55.7, Öl auf Leinwand, $61 \times 53 \mathrm{~cm}$. Aus der Ernst-Sammlung veröffentlicht von VARJú-HöllRIGL 1932, 50. Bei der Versteigerung der Ernst-Sammlung: Arverési Közlöny [Mitteilungsblatt für die Versteigerung], 1939. Nr. 105

${ }^{68}$ Die Erwähnungen des Bildnisses in den Inventaren werden in der neuen, als Dissertation erstellten, beispielhaft gründlichen Monographie des Kunsthistorikers vom Prado, José Juan Pérez Preciado, berücksichtigt, und zwar im Rahmen der wissenschaftlichen Bearbeitung der Sammlertätigkeit von Leganés und der katalogmäßigen Beschreibung seiner gesamten Bildersammlung: PRECIADO 2010. Die Kenntnis von dem Aufsatz verdanke ich Tibor Marti. Grundlage der Katalog-Bearbeitung von Preciado ist die Quellenpublikation Jose Lopez Navios, der das Inventar des Jahres 1655 im vollen Wortlaut veröffentlichte: NAvio 1962. Den bei ihm befindlichen Inventareintrag des Bildnisses von Ferdinand III. (290 [Nr. 475]) veröffentlichte Preciado mit einer gewissen Korrektur. Der Eintrag lautet in seiner präziseren, quellengetreuen Lesart (Vol. II. 348-349 [Nr. 475]) „El rey de ungria vestido a lo ungaro la corona ynperial [sic] sobre la mesa del $n^{\circ}$ quatroçientos y setenta y çinco lo taso en trezientos Reales [300]". Preciado kennt das Bild, das er ebenfalls für Sustermans Arbeit hält, aufgrund eines Fotos, von seinem Verbleib weiß er jedoch nichts. Mehr noch: Er wurde darüber unterrichtet - vermutlich aufgrund Richard de Willermins Informationen, der ihm die Kenntnis vom Bild und auch das Foto vermittelt hatte -, dass es bei einem Brand im 20. Jahrhundert vernichtet wurde. Die Geschichte entspricht nur zur Hälfte der Wahrheit: Es stimmt zwar, dass die Sammlung von William L. Eagleton, dem vorherigen Besitzer des Werkes (wie wir im Nachhinein erfuhren), Mitte der 1990er Jahre in einem Brandfall während der vorübergehenden Lagerung vernichtet wurde, das Porträt Ferdinands III. befand sich jedoch zu dieser Zeit bereits in der Ungarischen Nationalgalerie. Es handelt sich also um kein Duplikat: Das von Preciado veröffentlichte Bild und das Werk im Museum ist dasselbe Exemplar. Leganés' Sammlung war bis zum Beginn des 19. Jahrhunderts unangetastet beisammen. $\mathrm{Zu}$ dieser Zeit ließ sie der damalige Besitzer, Graf Altamira, versteigern. Siehe CRAWFORD-VOLK 1980, 
Anm. 262/35; sowie Preciado 2010, passim. Versteigerungen der Altamira-Sammlung - Frits Lugts Versteigerungsverzeichnis: (11.468) London, 1. Juni 1827; (11.978) Paris, Roux, 24.-25. März 1829; (13.355) London, 29. Juni 1833. Siehe LUGT 1953.

${ }^{69}$ Navio 1962, 290; Preciado 2010, Vol. II. 349 (Nr. 476): „La reyna de ungria su muger del no quatroçientos y setenta y seis la taso en trezientos reales [300]." Früheres Vorkommen im Inventar von Leganés Sammlung erwähnt er aus den Jahren 1630 und 1642, in beiden Fällen ebenfalls unter Nr. 476. Vom gleichen Schätzwert ausgehend sollte auch das Porträt der Königin ganzfigurig gewesen sein. Preciado kennt weder das Bild noch dessen Verbleib; seine letzte sichere Angabe darüber stammt aus dem Madrider Inventar aus dem Jahr 1655.

70 Über Diego Mexía Felipez de Guzmán, Marquis Leganés siehe neben der o. g. Monographie den Aufsatz mit kurzem Lebenslauf: CRAWFORD-VOLK 1980, 256-258; sowie in Zusammenhang mit dem Leganés-Porträt von Van Dyck: Splendeurs d'Espagne 1985, Bd. II. 435 (Kat.-Nr. B. 27); ferner siehe Enciclopedia Universal ilustrada, Madrid, 1958. Bd. XXVII. 401. Leganés ist 1625 bereits „Maistro de Campo General" des kastilischen Heeres, vom Februar 1626 an General der in den Niederlanden stationierten Kavallerie, dann wurde er im Juni selben Jahres vom spanischen König nach dem Verlöbnis von Ferdinand III. mit der Infantin Maria Anna zum Geheimrat ernannt. $\mathrm{Zu}$ all dem siehe KHEVENHILLER 1724, Bd. X. col. 1033, 1326, 1329

${ }^{71}$ Crawford-Volk 1980; Balis 1985, I. 283-296, dort: 290; sowie ebenda Bd. II. 435 (Kat.-Nr. B. 27). Siehe ferner: ARroyo Martín 2017, 338.

72 Crawford-Volk 1980, 261; Balis 1985, 290; sowie ARROYO MARTín 2017, 339.

${ }^{73} \mathrm{Zu}$ seinem Aufenthalt in Brüssel: CRAwFORD-VOLK 1980, 262; BALIS 1985, 290.

${ }^{74}$ CRAWFORD-VOlK 1980, 258, zu seiner Beziehung zu Rubens: 261-263.

${ }^{75}$ CrawFord-Volk 1980, 262-263, Foto des an einem unbekannten Aufbewahrungsort befindlichen Bildes ebenda, Abb. 12.

${ }^{76}$ Rubens' Brief vom 27. Januar 1628 an Pierre Dupuy, zitiert von CrawFord-Volk 1980, 258; sowie Balis 1985, 290; Splendeurs d' Espagne 1985, Bd. II. 435 (B. 27). Kurze Beschreibung der Sammlung, wobei auch ihr späteres Schicksal dargelegt wird: ARROYO MARTín 2017, 335-342.

${ }^{77}$ Ausführlich über das Inventar vom Jahr 1630: CRAWFORD-VOLK 1980, 258. Auszugsweise veröffentlicht ebenda: 266, Appendix 1; das 1642 aufgenommene Inventar der Sammlung, das er nach Malern gruppiert veröffentlicht, ebenda 267-268 (Appendix 2, 3, 4, 5, 6)

${ }^{78}$ Postenweise, aber nicht ganz quellengetreue Veröffentlichung des Inventars 1655: NAVIO 1962, 269-324.

${ }^{79}$ Crawford-VOLK 1980, 261.

${ }^{80}$ Er wird weder bei Khevenhiller noch in den Berichten der am Reichstag teilnehmenden Gesandten und Diplomaten erwähnt. Vgl. Hiller 1993, 258-260; sowie Aufsätze und Quellenausgaben im Band Az 1625. évi soproni koronázó országgyülés 2018

${ }^{81}$ Vgl. MeCENSEFFy 1955, 39. In Zusammenhang mit dem Ereignis wird Leganés namentlich genannt von: KHEVENHILLER 1724, Bd. X. col. 1084.

82 Preciado 2010, Vol. I-II.
${ }^{83}$ Crawford-Volk 1980, 257 und Anm. 7, 258 bzw 266-267, hier auch der Auszug des Inventars veröffentlicht; PreCiAdo 2010, Vol. I. 238

${ }^{84}$ Preciado 2010, Vol. I. 574/Anm. 2060, ebenda 405: ein Kapitel über den Tod seiner Gattin, insbesondere 407, über die am 22. Juni 1637 begonnene Inventur.

${ }^{85}$ Die mit den wichtigsten Stationen des Lebens des Marquis verbundenen Inventarperioden werden in Bezug auf Rubens-Werke in der Sammlung behandelt von: PRECIADO 2010, Vol. I. 678 bzw. Vol. II. 5

${ }^{86}$ Die aus sammlungsgeschichtlicher Sicht wichtigen Eigenschaften der drei letzten Inventare veröffentlicht der Autor am Anfang des zweiten Bandes der Monographie (der den Katalogteil ausmacht) samt Inventarnummern, verbunden mit den Perioden des Erwerbs (PRECIADo 2010, Vol. II 5). Demnach sind die vor 1637 erworbenen Werke bis zur Nr. 750, die 1642 aufgenommenen Werke bis zum Posten 1147 registriert, während die Nummerierung bis 1333 die bis zu seinem Tod zu ihm gelangten Werke enthält.

${ }^{87}$ All das zeigt in die Richtung, dass der Großteil der vor der Inventaraufnahme 1637 erworbenen Werke während der Inventarisierung nicht am selben Standort aufbewahrt war. Dazu fand ich allerdings keinen Anhaltspunkt in der Monographie.

${ }^{88}$ Preciado hält das Porträt für eine Erwerbung vor dem Jahr 1634, als eines der Werke, die vor Leganés' niederländischer Reise mit dem Kardinalinfanten Ferdinand nach Spanien gekommen sein könnten. Preciado 2010, Vol. II. 348.

89 „Ferdinandvs III. Hvngariae DalmatiÆ / Rex. ARChidvx AvstriÆ .../ (A)nNOS XVII(I ?) An(N)O DOMINI M. D ... XXVI DIE (?) XIII (?) MENSIS IANVARII ..." Die mit schwarzer Farbe gemalte Inschrift sickerte aus der ursprünglichen Leinwand auf die Oberfläche der hinten deckenden Dublierleinwand durch. Sie kann auch mit restauratorentechnischer Untersuchung (Infrarotlampe) nur schwer und nur teilweise entziffert werden.

${ }^{90}$ In Sustermans' Fall wurden hier nur die während seiner Tätigkeit in Wien beziehungsweise für die Herrscherfamilie gefertigten, unter Einbeziehung von Gehilfen und in mehreren Exemplaren ausgeführten Werke erwähnt: Kaiser Ferdinand II., 1623/1624 (Exemplare: Wien, KHM; Firenze, Palazzo Pitti, siehe HeInZ-Schütz 1976, Nr. 96); Kaiserin Eleonore Anna von Gonzaga, 1621 (Exemplare: Wien, KHM; Mantova, Palazzo Ducale, siehe HeINZ-SchÜtz 1976, Nr. 241); Ders., 1623-1624 (Exemplare: Wien, KHM; Mantua, Palazzo Ducale, siehe Heinz-SchÜtz 1976, Nr. 242). Siehe dazu noch Marco Chiarinis Feststellung in: Artisti alla corte granducale 1969, 43.

${ }^{91}$ Eine Angabe bezüglich Sustermans' Aufenthalt: eine Auszahlung am 14. Mai 1626, die dem Maler für die großformatige Komposition mit dem Titel Giuramento d'obbedienza dei senatori fiorentini a Ferdinando II. de'Medici zustand. Siehe ChiARINi 1984, 78, 83, mit der Veröffentlichung des Zahlungseintrags. Zu dieser Zeit weilte der Maler bereits in Florenz, umso mehr, da die Übergabe und die Platzierung des Bildes im Palazzo Pitti am 27. Mai 1626 erfolgten. (Siehe Sustermans. Sessant'anni alla corte dei Medici 1983, 17; sowie Kat.-Nr. 24 bzw. Posten LXXIV - hier statt der Übergabe im Mai mit dem falschen Datum von März; CHIARINI 1984 83). Chiarinis Meinung, wonach das "Giuramento" in den Jahren 1625-1626 entstand, basiert auf dem Fakt der Aus- 
zahlung. Zugleich nimmt er in Bezug auf eine Skizze des Bildes an (Florenz, Uffizi), dass der Maler nach seiner Rückkehr aus Wien (Oktober 1624) schon mit der Ausführung der großformatigen Komposition begann (siehe Sustermans. Sessant'anni alla corte dei Medici 1983, 45 [Kat.-Nr. 24]).

92 Zum spanischen Gesandten vgl. MarTí 2018.

93 Siehe dazu Preciado 2010, Vol. I. 221 bzw. Vol. II. 62 (Nr. 59).

94 Thieme-Becker Bd. 32. (1938) 323; Bautier 1912; Sustermans. Sessant'anni alla corte dei Medici 1983, 11 sowie 17, chronologischer Überblick.
${ }^{95} \mathrm{Zu}$ Sustermans' einjährigem Wiener Aufenthalt bzw zu seinen Arbeiten für die Herrscherfamilie in dieser Zeit: CHIARINI 1984, 79; BAUTIER 1912, 59-60; CRINÒ 1955, 217; HeInz 1963, 148-149; Erzherzog Ferdinands heute noch nicht identifiziertes Porträt, erwähnt auch bei: Sustermans. Sessant'anni alla corte dei Medici 1983, 17 (Chronologie); ferner seine Rückkehr aus Wien im Oktober 1624 präzisiert: 45 (Kat.-Nr. 24). Als neuerer Überblick über die Kunstbeziehungen zwischen Wien und Florenz: Splendore dei Medici 1999.

${ }^{96}$ BaUtier 1912, 62-63; CRINÒ 1955, 217; Sustermans. Sessant'anni alla corte dei Medici 1983, 12, 17. 